$11-2003$

\title{
Archeological Excavation and Reburial of Unmarked Historic Graves in the Pioneer Cemetary (41B0202), Brazoria County, Texas
}

Angelina L. Tiné

Prewitt and Associates, Inc.

Douglas K. Boyd

Prewitt and Associates, Inc.

Follow this and additional works at: https://scholarworks.sfasu.edu/ita

Part of the American Material Culture Commons, Archaeological Anthropology Commons, Environmental Studies Commons, Other American Studies Commons, Other Arts and Humanities Commons, Other History of Art, Architecture, and Archaeology Commons, and the United States History Commons

Tell us how this article helped you.

This Article is brought to you for free and open access by the Center for Regional Heritage Research at SFA ScholarWorks. It has been accepted for inclusion in Index of Texas Archaeology: Open Access Gray Literature from the Lone Star State by an authorized editor of SFA ScholarWorks. For more information, please contact cdsscholarworks@sfasu.edu. 


\section{Archeological Excavation and Reburial of Unmarked Historic Graves in the Pioneer Cemetary (41B0202), Brazoria County, Texas}

\section{Creative Commons License}

\section{(c) (i) $\Theta($}

This work is licensed under a Creative Commons Attribution-NonCommercial-No Derivative Works 4.0 International License. 


\title{
ARCHEOLOGICAL EXCAVATION AND REBURIAL OF UNMARKED HISTORIC GRAVES IN THE PIONEER CEMETERY (41BO202), BRAZORIA COUNTY, TEXAS
}

\author{
by \\ Angela L. Tiné \\ and \\ Douglas K. Boyd
}

Principal Investigator: Douglas K. Boyd

REPORTS OF INVESTIGATION, NUMBER 139

Prewitt and Associates, Inc.

Cultural Resources Services

Austin, Texas

ARCHEOLOGICAL STUDIES PROGRAM, REPORT NO. 59

Texas Department of Transportation

Environmental Affairs Division

Austin, Texas

November 2003

TEXAS ANTIQUITIES PERMIT NO. 3080 


\title{
ARCHEOLOGICAL EXCAVATION AND REBURIAL OF UNMARKED HISTORIC GRAVES IN THE PIONEER CEMETERY (41BO202), BRAZORIA COUNTY, TEXAS
}

\author{
Copyright (C) 2003 \\ Texas Department of Transportation (TxDOT)
}

TxDOT and Prewitt and Associates, Inc., jointly own all rights, title, and interest in and to all data and other information developed for this project under Contract No. 573XXSA001. Brief passages from this publication may be reproduced without permission provided that credit is given to TxDOT and Prewitt and Associates. Permission to reprint an entire chapter, section, figures or tables must be obtained in advance from the Supervisor of the Archeological Studies

Program, Environmental Affairs Division, Texas Department of Transportation, 125 East $11^{\text {th }}$ Street, Austin, Texas, 78701. Copies of this publication have been deposited with the Texas State Library in compliance with the State Depository Requirement.

jointly published by the

Texas Department of Transportation

Environmental Affairs Division

Archeological Studies Program

Owen Lindauer, Ph.D., Supervisor

Archeological Studies Program, Report No. 59

and

Prewitt and Associates, Inc.

Cultural Resources Services

Austin, Texas

Reports of Investigations No. 139

Contract \#573XXSA001

Printed at Morgan Printing in Austin, Texas 


\section{TABLE OF CONTENTS}

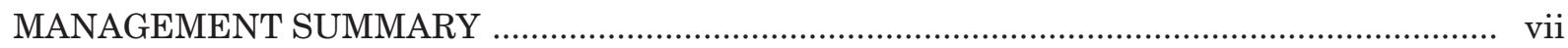

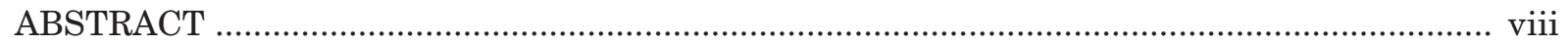

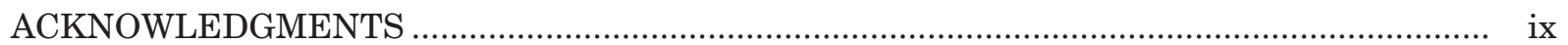

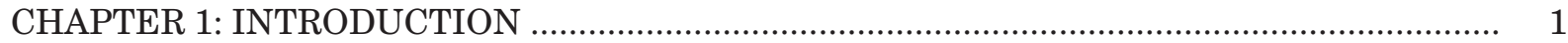

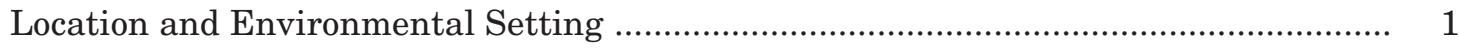

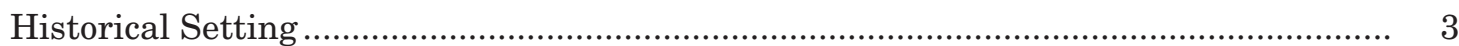

CHAPTER 2: HISTORIC BACKGROUND .................................................................... 7

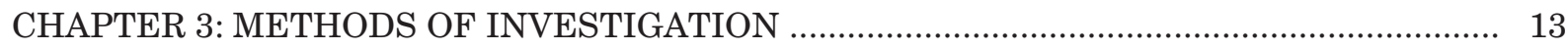

Re-location of Unmarked Graves ............................................................................. 13

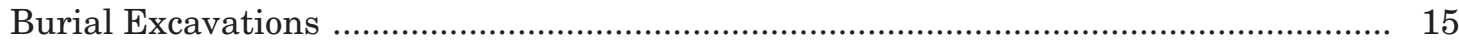

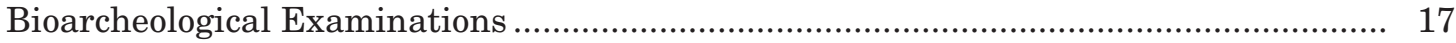

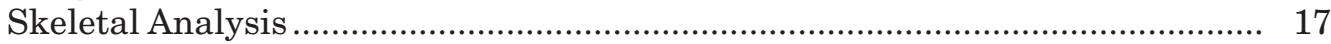

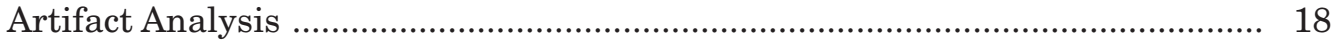

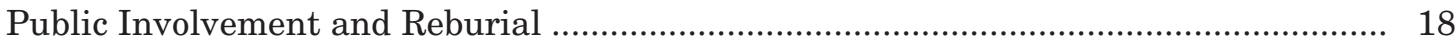

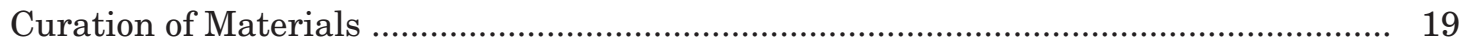

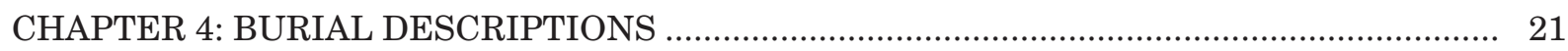

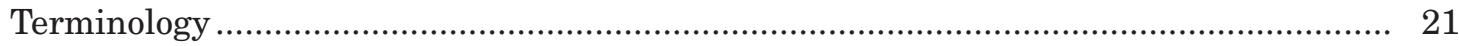

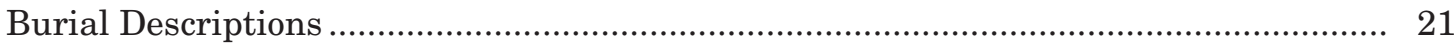

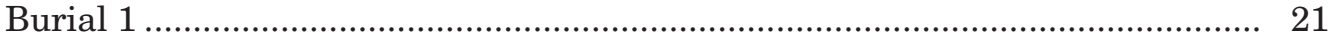

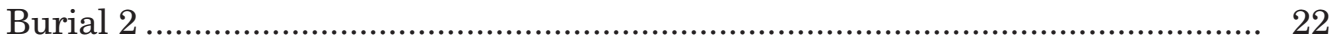

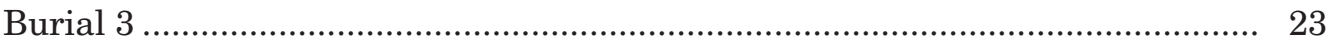

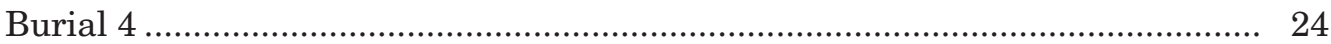

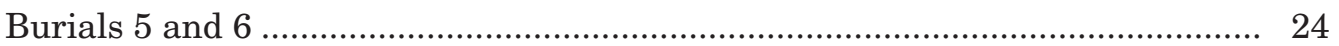

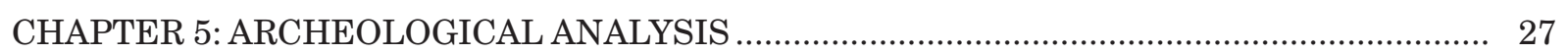

General Mortuary Trends of the Late Nineteenth Century ...................................... 27

Burial Containers ....................................................................................... 27

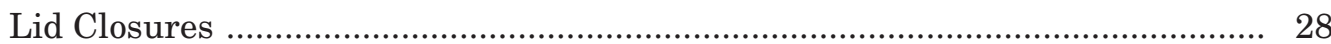

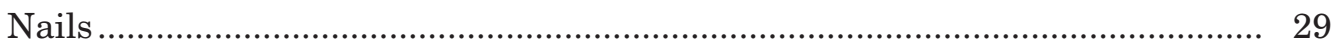

Analysis of Mortuary Hardware and Personal Effects .............................................. 29

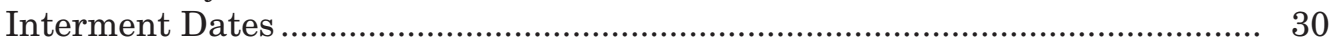

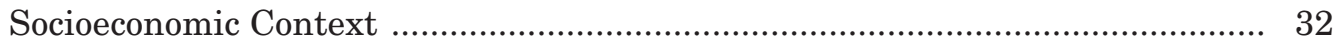

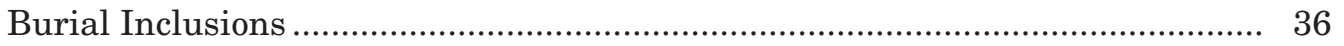

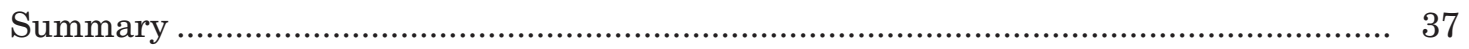

CHAPTER 6: BIOARCHEOLOGICAL ANALYSIS …............................................................. 39

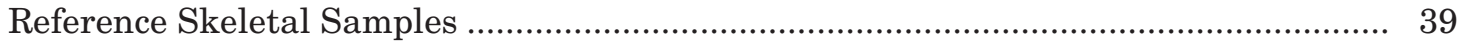

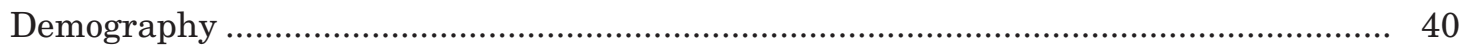

Biological Affinity and Ethnicity ……......................................................... 40

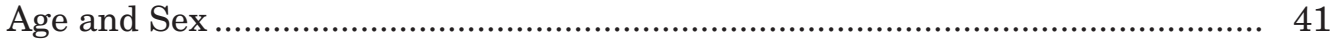




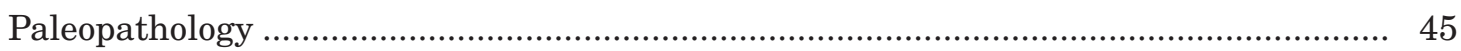

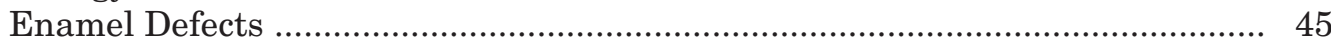

Porotic Hyperostosis and Cribra Orbitalia ..................................................... 47

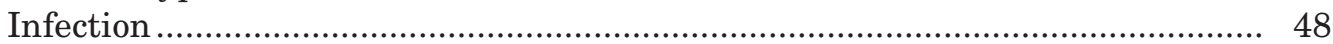

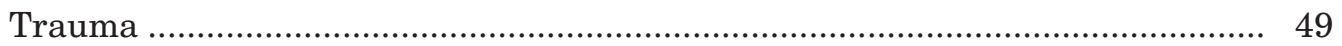

Degenerative Conditions and Biomechanical Stress .................................... 50

Miscellaneous Skeletal Disorders ............................................................. 51

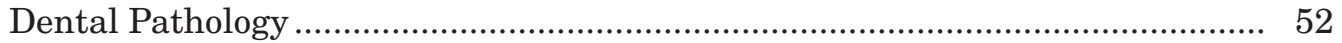

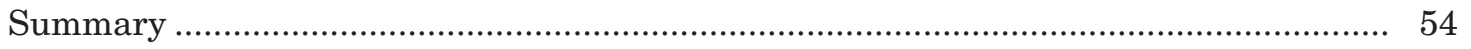

CHAPTER 7: SUMMARY AND SYNTHESIS ..................................................................... 57

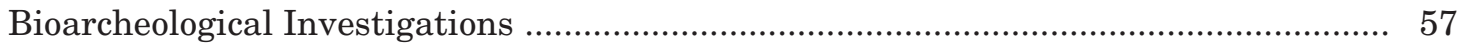

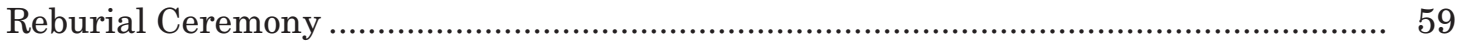

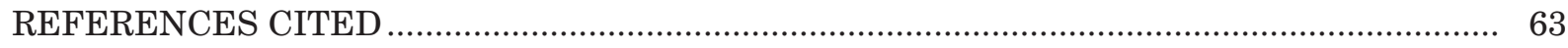

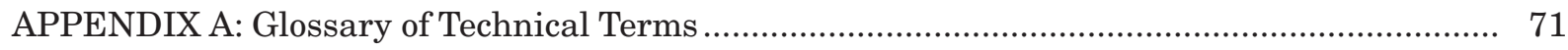

APPENDIX B: Burial Excavation and Artifact Identification Forms ....................................... 77

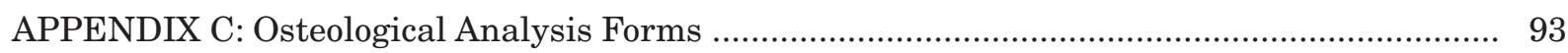

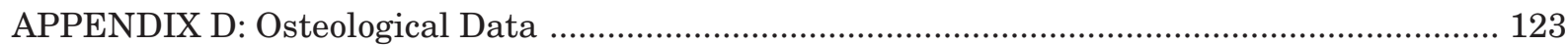




\section{LIST OF FIGURES}

1.1. Aerial photo and plan map showing the location of Pioneer Cemetery

1.2. Comparison of the African American historical population data for Brazoria County and Texas

1.3. Percentage of African Americans within the total populations of Brazoria County and Texas

2.1. Plat map showing Pioneer Cemetery and lots within Brazoria townsite Block 42 .......... 11

3.1. Unmarked graves within TxDOT's State Highway 332 ROW ....................................... 14

3.2. Overview of Burials 5 and 6 showing concrete cap over the west ends

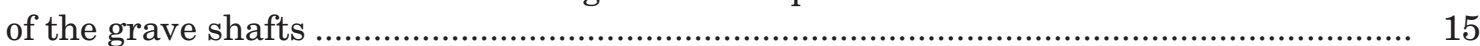

3.3. Hand excavation of Burial 1, looking west ............................................................. 16

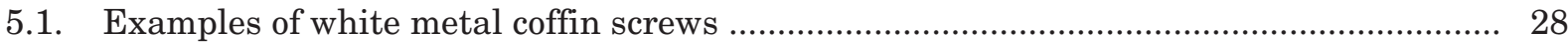

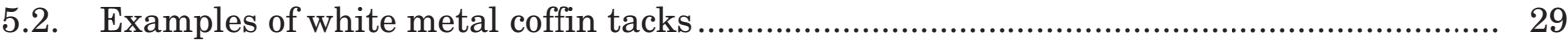

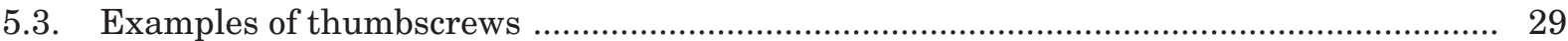

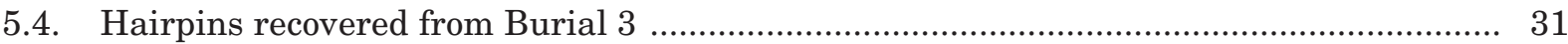

5.5. Hair clip, finger ring, and earrings recovered from Burial 3 ........................................ 32

5.6. Porcelain buttons and slate fragment recovered from Burial 4 ...................................... 32

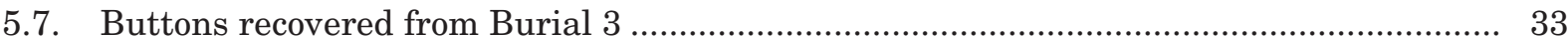

5.8. Metal toolbox lid found above Burial 1 that may have served as a gravemarker ............ 36

6.1. Comparison of age at death for two large historic cemetery samples ............................. 42

6.2. Numbers of marked burials in Pioneer Cemetery by age category ................................. 44

6.3. Temporal distribution of marked burials in Pioneer Cemetery ...................................... 45

7.1. Some of the participants during the final prayer that concluded the

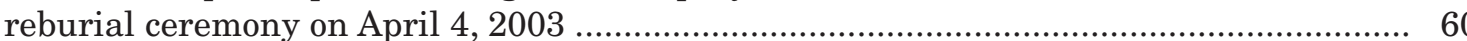

7.2. Four women who came to the reburial ceremony and have relatives buried in Pioneer Cemetery 


\section{LIST OF TABLES}

2.1. Chronology of Pioneer Cemetery history .................................................................. 8

6.1. Frequencies of enamel hypoplasia among various historic cemetery samples ................ 46

6.2. Frequencies of porotic hyperostosis and cribra orbitalia among various

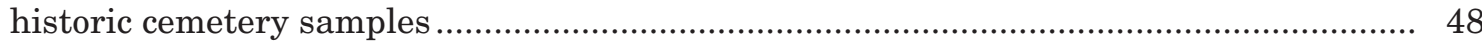

6.3. Frequencies of skeletal infection among various historic cemetery samples .................. 48

6.4. Frequencies of trauma among various historic cemetery samples ............................... 50

6.5. Frequencies of degenerative disorders among adults from various historic cemetery

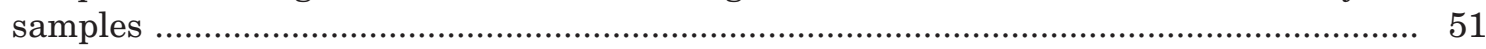

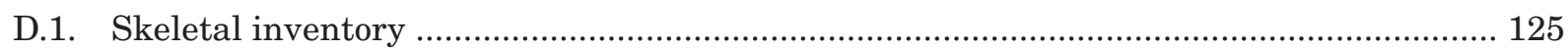

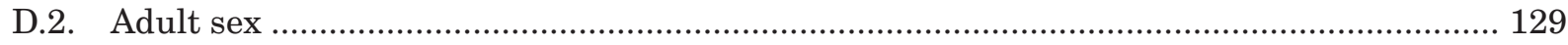

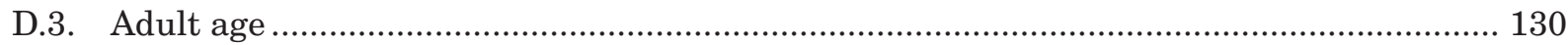

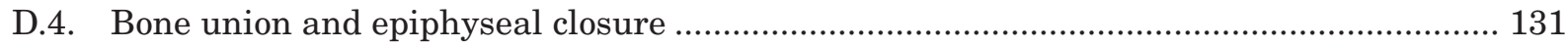

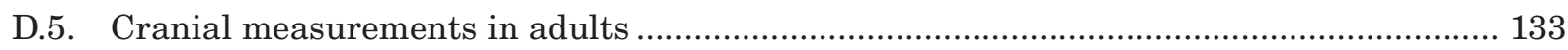

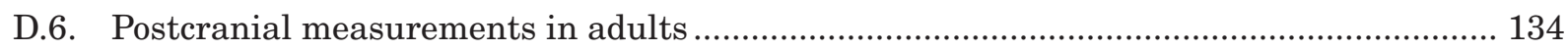

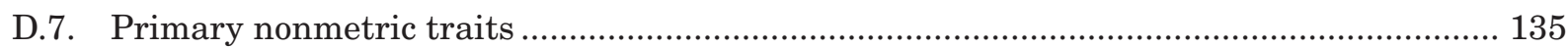

D.8. Dental inventory, development, wear, and pathology of permanent teeth ...................... 137

D.9. Dental inventory, development, and pathology of deciduous teeth ................................ 141 


\section{MANAGEMENT SUMMARY}

This report signals the completion of a cultural resource consultation process that began several years ago. In 1998, a planning meeting was held between archeologists with the Texas Department of Transportation and the Texas Historical Commission to discuss the planned improvements to State Highway 332 in Brazoria County, Texas, This work required a cultural resources surveys of many segments of the highway, one of which is adjacent to the historic Pioneer Cemetery, a predominantly African American burial ground in the town of Brazoria. Archeological investigations were conducted adjacent to the cemetery but within the highway right of way in 1998 and 1999 , and the results of this work were reported in 2002. The investigations identified several unmarked graves that appeared to be within the highway right of way on the east side of SH 332 . A subsequent property survey showed that three well-defined graves, and a possible fourth grave, were within the right of way and two others were very close to the right of way line. Following the state and federal cultural resources laws and the state laws pertaining to cemeteries in the Health and Safety Code of Texas, the Texas Department of Transportation undertook a project to remove and relocate the graves within the highway right of way. Prewitt and Associates, Inc., of Austin, Texas, was contracted to do the work (Contract No. 573XXSA001, Work Authorization No. 57304SA001). The exhumation of the burials took place from March 31 to April 3, 2003, and the remains were reburied during a ceremony held on April 4, 2003.

This report documents the excavation, removal, and reburial of three unmarked graves dating to the late nineteenth or early twentieth centuries. This archeological study brings closure to this project. From a historical perspective, the remains of three unidentified people-a young woman, an older woman, and an infant-provide a glimpse at African American life in turn-of-thecentury Brazoria. From a human perspective, the remains from each grave-all human bones, remnants of the wooden caskets, and personal items buried with the person-were treated with the respect and dignity they deserve, and all three have been reburied in a new location safely inside the Pioneer Cemetery. 


\begin{abstract}
Three unmarked graves within the predominantly African American Pioneer Cemetery in the City of Brazoria (Brazoria County), Texas, were exhumed and reburied within the cemetery. The graves were located within the right of way of State Highway 332, and were found during an earlier search phase done in conjunction with a planned expansion of the highway. The burial excavations and reburial were done in March and April 2003, by Prewitt and Associates, Inc., for the Texas Department of Transportation (TxDOT). The graves contained the remains of three unknown individuals - a young woman (17-23 years old), an older woman (45-60 years old), and an infant (2-4 years old) — who died in the late nineteenth or early twentieth centuries.
\end{abstract}




\section{ACKNOWLEDGMENTS}

Douglas K. Boyd served as principal investigator, and Angela Tiné, an employee of GeoMarine, Inc., served as a consultant in the capacity of project archeologist and physical anthropologist/osteologist. The field crew consisted of Cory Broehm, Greg LaBudde, Hedy Justus, and Weldon Hammond. They did an excellent job despite the often chaotic happenings around them.

Prewitt and Associates, Inc. (PAI), contracted with Brazos M\&E to provide earth-moving equipment, and Mr. Al Linder was the key contact. Mr. James Ringo was the equipment operator and ran the backhoe and small bulldozer throughout the project. His skill and attention to detail helped make the job much easier. Mr. David Jordan, the public works supervisor for the City of Brazoria was extremely helpful. He located the buried gas line and assisted us while we were digging close to it, provided us with the safety barricade, and helped with the daily tasks of setting up and moving the excavation barriers.

TxDOT archeologist Allen Bettis was present during the entire project and assisted us with various tasks. Most importantly, he served as the public affairs correspondent when visitors and members of the press dropped by. Mr. Owen Lindauer, TxDOT's director of the Archeological Studies Program, Environmental Affairs Division, also visited the project and was there at a crucial time. He was involved in the most important on-site meetings between TxDOT personnel and local cemetery representatives. Mr. Lindauer also helped the group reach a consensus as to which burials should be excavated and where to rebury them.

Special thanks go to Mr. Traversia Viola and Mrs. Ora Kennedy. Mr. Viola is the caretaker of the Pioneer Cemetery and was involved throughout the project, from prefield planning to the reburial ceremony. He donated the use of the large tent, tables, and chairs used to house our field laboratory and was extremely helpful in many other ways. Ms. Kennedy is the representative of the Pioneer Cemetery Association.

The people of Brazoria and Brazoria County were most helpful and were active participants in the project. Brazoria City Manager Tom Smizer made sure that city personnel cooperated with our efforts, and Chief of Police Neal Longbotham provided increased security patrols while our excavations were in progress. Brazoria mayor, Ken Corley, visited the project daily to make sure we had everything we needed. He also was the key person who helped plan and coordinate the reburial ceremony on the last day of the project. Many members of the cemetery committee of the Brazoria County Historical Museum visited and assisted in the project. Most notably, Ms. Nancy Howard was there almost every day and helped out in many ways. She also provide us and TxDOT with her most current listing of headstone data for the Pioneer Cemetery. Other members who visited and helped out were: Debra Bess, Bill Fletcher, Elois Gibbs, Lou Harris, Lou Hunter, Charlene Hurta, Roy Karl, Billy Koenning, Bobby Koenning, Terrance Mish, David Pettit, David Roberts, Max and Alice Royalty, Alma Hobbs Spears, Reverend Sampson Thompson Jr., Lon Tullos, and Ed Wilkes (apologies to anyone who was unintentionally left out).

This report is the work of many different people. The figures were produced by Sandy Hannum, and the text editing was done primarily by Audra L. Pineda and Douglas K. Boyd. Cory Broehm also helped edit several chapters. Allen Bettis reviewed this report for TxDOT, and Mark Denton reviewed this report for the Texas Historical Commission. 



\section{INTRODUCTION}

Pioneer Cemetery was established in 1888 as a burial ground for the use of members of two African American churches. Other churches began to use the cemetery in the twentieth century, and Pioneer Cemetery continued to be used mainly by African Americans throughout its history. Fifty-nine graves are marked with headstones, but many hundreds of unmarked graves may exist. The cemetery is still being used today9 graves date to the 1990 s or 2000 .

State Highway 332 (SH 332), with its bridge over the Brazos River, was constructed adjacent to the cemetery in 1939, and the Texas Department of Transportation (TxDOT) is currently involved in a project to replace the historic bridge and widen the highway approaches to the bridge. In 1999, TxDOT archeologists used a Gradall to search for unmarked graves along the east side of the cemetery. Six graves (designated Graves 1-6) were found within or near the SH 332 right of way (ROW). In 2003, TxDOT contracted with Prewitt and Associates, Inc. (PAI), to re-locate the graves and exhume, analyze, and rebury the remains. The fieldwork was done from March 31 to April 4, 2003, and this report describes the methods and results of this project.

Of the six unmarked graves, PAI archeologists re-located three that were completely within the SH 332 right of way. These three unmarked graves (Graves 1, 3, and 4) were excavated, the mortuary and human remains they contained were analyzed on site, and the remains from each were placed inside individual reburial boxes. Archeologists from PAI did not find the other grave located within the right of way (Grave 2), which was described in 1999 as "only the smallest soil disturbance seen in the side-wall as the trench was excavated"
(Dismukes and Bettis 2002:11). After careful examination of the area, it was concluded that this anomaly likely was a natural feature such as a tree root disturbance. The other two unmarked graves (Graves 5 and 6) were found very close to the right of way line in 1999, but the precise location of the line had not been surveyed at that time. When PAI archeologists re-located these grave shafts and the precise right of way line was established, they were found to straddle the line. More than three-fourths of each grave was determined to be inside the cemetery property, and the west ends of the shafts extended less than $30 \mathrm{~cm}$ (12 inches) into the TxDOT highway right of way. Since this area would not be impacted by the road project, these two graves were left in place, capped with concrete, and marked with metal poles. Immediately following the archeological work, PAI and TxDOT personnel assisted in a reburial ceremony in which the remains exhumed from the three graves were reinterred by the local community on Friday, April 4, 2003.

\section{LOCATION AND ENVIRONMENTAL SETTING}

The City of Brazoria is located on either side of the Brazos River, about $29 \mathrm{~km}$ (18 miles) upstream from where it empties into the Gulf of Mexico near the community of Surfside. Pioneer Cemetery covers an area of approximately $8,243 \mathrm{~m}^{2}$ or 2.04 acres, ca. $270 \mathrm{~m}$ (885 ft) south of the Brazos River. It is located within the city and is bounded on all four sides by roads or railroads (Figure 1.1). The west side of the cemetery is bordered by SH 332 and on the east by the Union Pacific Railroad. Immediately north of the cemetery is County Road 400, or old Camp 


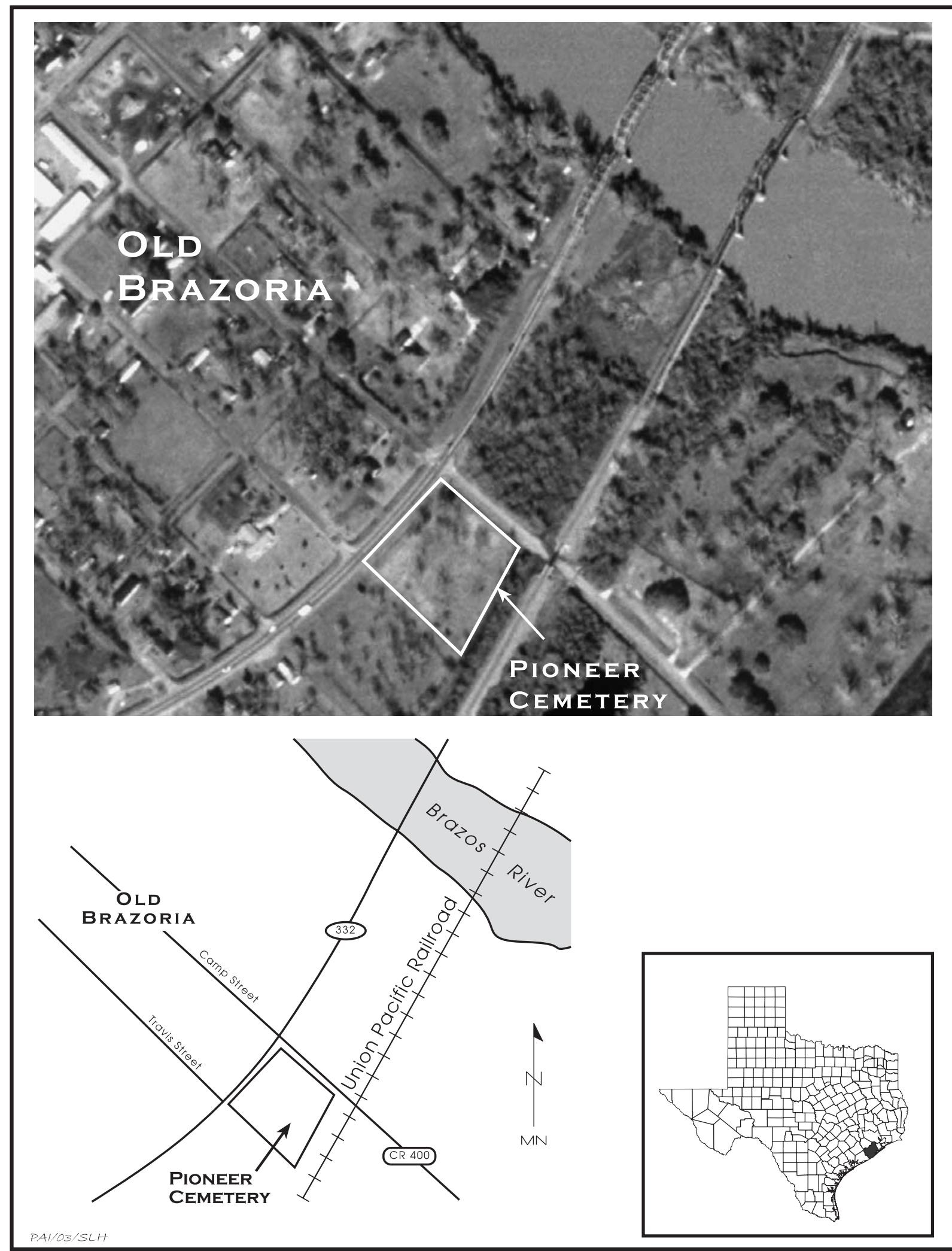

Figure 1.1. Aerial photo and plan map showing the location of Pioneer Cemetery in Brazoria, Texas. 
Street as shown on the Old Brazoria townsite plat maps. The Old Brazoria townsite maps show Old Travis Street on the south side of the cemetery, but there is only an unimproved road that marks this edge of the cemetery, and Travis Street currently stops on the west side of SH 332.

Pioneer Cemetery is situated within the broad Brazos River alluvial valley close to the head of the river delta. The river valley is approximately $25 \mathrm{~km}(15.5 \mathrm{mi})$ wide at this point, and the cemetery is approximately 20 $25 \mathrm{ft}$ above sea level and 13-15 ft above the mean water level of the Brazos River. The valley is inset into the Pleistocene deltaic clays that comprise the Beaumont Formation (Barnes 1982). The soils in the vicinity of the cemetery are classified as Asa silty clay loam. As described by the United States Department of Agriculture (1981:10):

Typically, this soil has a surface layer of neutral, very dark grayish brown silty clay loam about 14 inches thick. The subsoil from 14 to 60 inches is moderately alkaline, calcareous silty clay loam that is reddish brown in the upper part and yellowish red in the lower part.

Aronow (1981:81) notes that the Holocene deposits of the Brazos River have "a characteristic reddish-brown or yellowish-red color" that is seen in the Asa series soils. He also states: "This reddish ferric-oxide pigment is traditionally thought to be derived from the Permian red beds into which the drainage basins of these streams penetrate several hundred miles to the north and west." This color stratification is significant because it made it easy for previous investigators to see grave shafts when they were dug down into the reddish subsoil. Below about $40 \mathrm{~cm}$ deep, the grave shafts at Pioneer Cemetery appeared as dark mottled fill surrounded by the undisturbed reddish brown clay loam. More detailed climatic, geologic, and environmental data for the Brazoria area are found in Dismukes and Bettis (2002) and the United States Department of Agriculture (1981).

\section{HISTORICAL SETTING}

The historical setting for Brazoria County, Old Brazoria, and Pioneer Cemetery is summarized in detail by Dismukes and Bettis
(2002:4-6, 10-11, 13-14, 39-40, and 44-50). This information will not be repeated here, but a very brief overview of the nineteenth and early twentieth century history is presented, with an emphasis on the African American population. Much of the information is taken directly from Dismukes and Bettis (2002), with some additional information derived from the Handbook of Texas, under the headings Brazoria County (Kleiner 2002) and Brazoria (Hallstein 2002), and United States Census Data available online (Forestall 1995; University of Virginia 1998).

The townsite of Brazoria is on the Stephen F. Austin land grant and was initially laid out by John Austin in 1828. With its prominent location on the Brazos River, it served as a major regional shipping center for plantation products bound for New Orleans and Europe. By the 1830s, cotton and other produce from Austin's "Old Three Hundred" plantations were being shipped out of Brazoria on steamboats and sailing ships. Brazoria began under Mexican rule, but was plundered by Mexican troops in 1836 after Texas declared its independence. Under the new Republic of Texas, Brazoria County was established by the Congress in March 1836, and its current boundaries were established by 1838. Cotton gins, sugar mills, and a school were operating in or near Brazoria by 1838 , and a post office was established in 1846. The town continued to thrive and prosper during most of the latter half of the nineteenth century.

Prior to the Civil War, the region's agricultural economy was based primarily on slave labor and large plantations. Between 1850 and 1860 , there were 46 plantations that produced mainly cotton and sugar. In 1840 , the 80 slaveholders in Brazoria County owned a total of 1,316 slaves, but by 1847 the county had 3,013 slaves and only 1,623 white inhabitants. The 1860 census shows that the population of Brazoria County had risen to 2,027 whites and 5,116 blacks, with only 6 of the latter being free black residents. After the Civil War, the plantations were broken up into smaller farms or ranches, but agriculture remained the dominant economic venture for most residents of Brazoria County. The African American population remained stable for some time, so the former slaves appear to have stayed in the same area. The population in the county was 7,527 in 1870 and 5,736 people (76 percent) were black. 
Brazoria County grew to 9,774 residents by 1880 , and 7,775 people were black ( 80 percent).

Brazoria County had a large black population by 1881 , seven years before the Pioneer Cemetery began. Three years later, in 1884 , the town was described as a "stirring village" of 800 people (Hallstein 2002). Brazoria became the county seat of Brazoria County in 1836, and its regional prominence lasted for 39 years. Like many towns across the country, however, Brazoria declined in population and status after the railroad bypassed it. The nearby town of Angelton became the new county seat in 1897, and quickly became the dominant city in Brazoria County.

With more than 8,523 blacks appearing in the 1890 census and 8,219 blacks in the 1900 census, the African American population of Brazoria County had reached its peak for the period 1850 to 1950 . By 1910, the population trend had reversed; the number of blacks actually declined and whites outnumbered blacks in the county for the first time. Out of a total population of 13,299 in 1910, there were 6,237 blacks and 7,051 whites. By 1920 , the county population of 20,614 consisted of only 6,574 blacks, while the 12,484 whites represents a significant increase. The African American population continued to increase, albeit slowly, over the next several decades.

The census data for Brazoria County tell some interesting stories. While the numbers of black people in Brazoria County denote slow but steady growth throughout the late nineteenth and early twentieth centuries (Figure 1.2), with the exception of a marked decline between 1900 and 1910, the percentage of black people within the county (Figure 1.3) tells a different story. The overall population trend observed for black people in Brazoria County seems to mimic that of the black population for the whole state. While there was general slow and steady growth in the numbers of blacks through time, the growth is minimal and totally overshadowed by the rapid growth of the white population. The significant increases in the Anglo American population were brought on by movements of large numbers of people into the region, while the limited growth in the African American population probably represents increases due to births within the region. It is important to note that Pioneer Cemetery appeared in Brazoria at a time when the African American population was increasing, and the first two decades of its use occurred as the black population reached its peak in the county (i.e., 1890 had the highest black population for the period 1850-1950). 


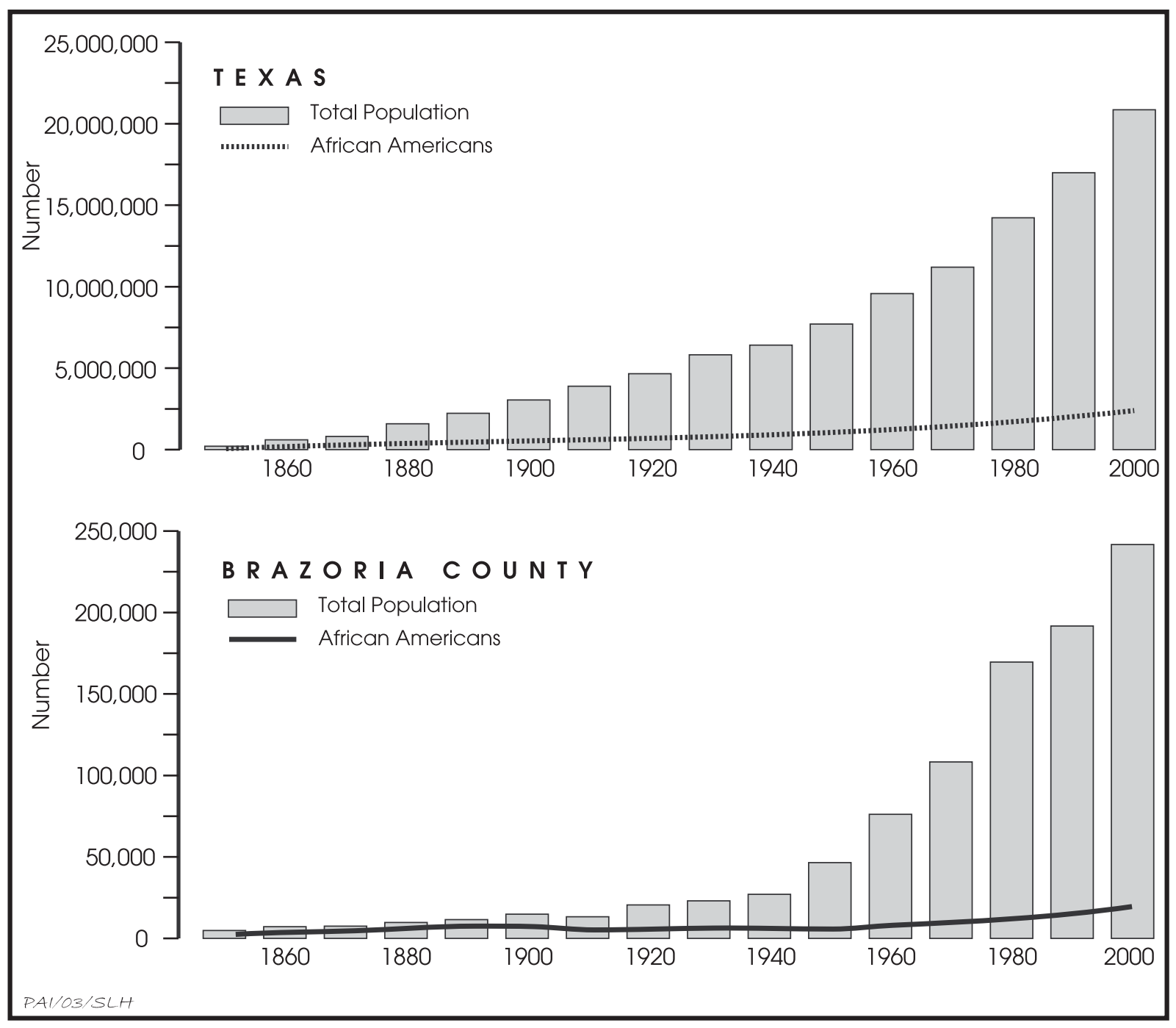

Figure 1.2. Comparison of the African American historical population data for Brazoria County and Texas. From online United States Census data by Forestall (1995) and University of Virginia (1998). 


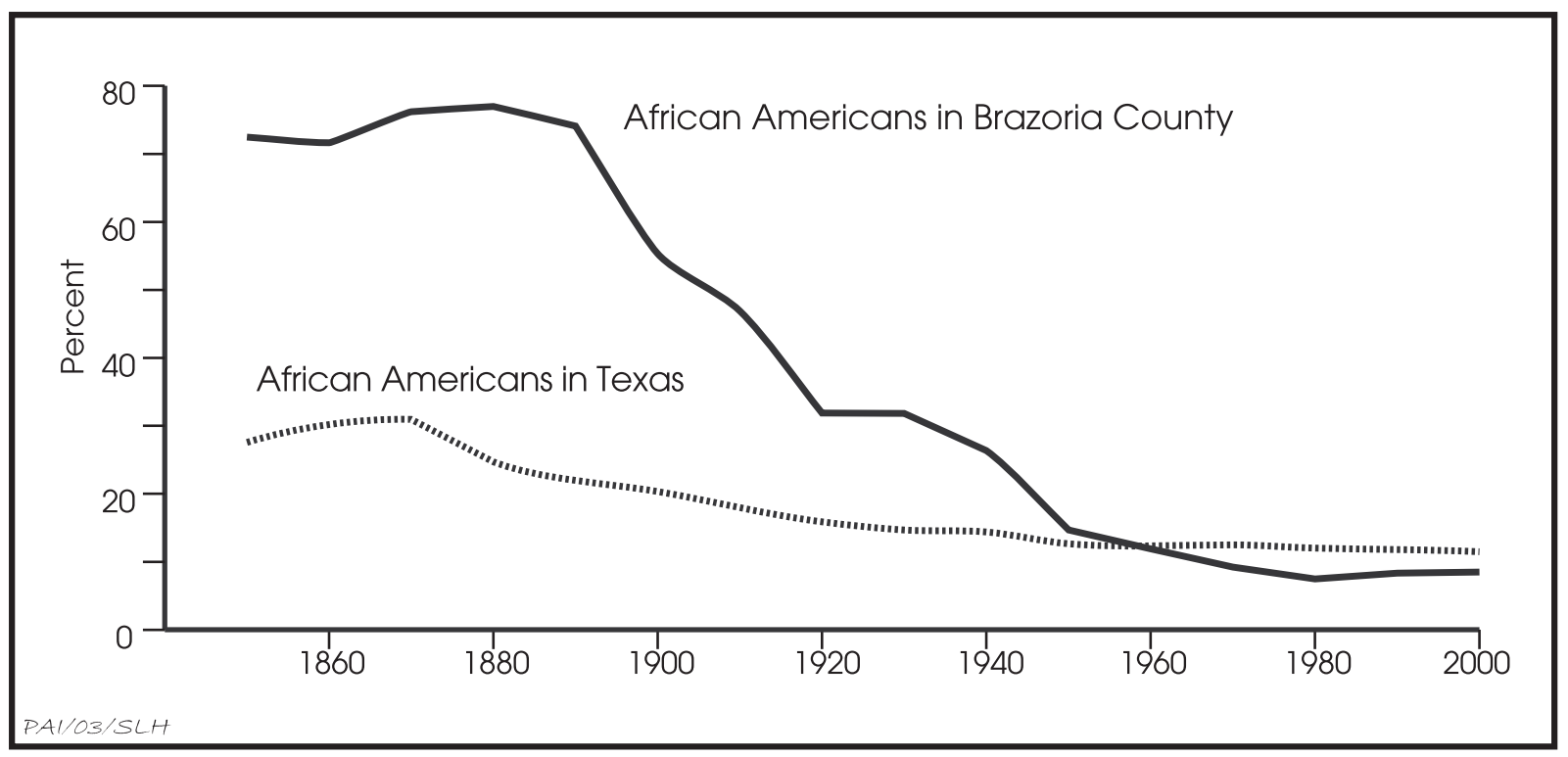

Figure 1.3. Percentage of African Americans within the total populations of Brazoria County and Texas. From online United States Census data by Forestall (1995) and University of Virginia (1998). 


\section{HISTORIC BACKGROUND}

In 1999, TxDOT personnel conducted detailed archival and informant research and compiled a history of the Brazoria Pioneer Cemetery. Like the history of the cemetery itself, the history of the historical and archeological investigations pertaining to Pioneer Cemetery is complex. Most of the historical data is presented in detail by Dismukes and Bettis (2002). The detailed information is not repeated herein, but this chapter presents a brief summary of the history of the cemetery, along with a chronological summary of the investigations. A brief chronology of the important events in the history of Pioneer Cemetery is presented in Table 2.1.

Several facts about Pioneer Cemetery are notable. Documentary evidence shows that the cemetery did not begin until the initial land was acquired in 1888, and the cemetery was expanded first in 1891 and again in 1986. The cemetery has been used as a burial place for members of several different churches over the past 115 years, and it appears that the burials were predominately African American. No precise records of interments were made, and it is not known how many graves are present (Mr. Traversia Viola, personal communication 2003). A listing of grave headstone data, updated through 2003, shows that 59 marked graves are present (Howard 2003), but a great many more unmarked graves are likely.

As seen in Table 2.1, there are some discrepancies in the summary of the historical evidence, particularly the facts related to which town lots are actually part of the cemetery and the locations of the cemetery's boundaries (Figure 2.1). Although the Pioneer Cemetery Association has submitted an application for a Historic Texas Cemetery designation (Mr. Traversia Viola, personal communication 2003), the Texas Historical Commission has not approved the application due to uncertainties regarding the cemetery's boundaries (Gerron Hite, personal communication 2003).

Prewitt and Associates, Inc. became involved with Pioneer Cemetery in early March 2003, when the firm contracted with TxDOT to exhume and remove the unmarked graves within the SH 332 right of way. The fieldwork was completed between March 31 and April 4, 2003. Analysis of burial data and comparative historic research was done from April through June 2003. The remainder of this report presents the methods and findings of these bioarcheological investigations. 
Excavation and Reburial of Unmarked Historic Graves in the Pioneer Cemetery

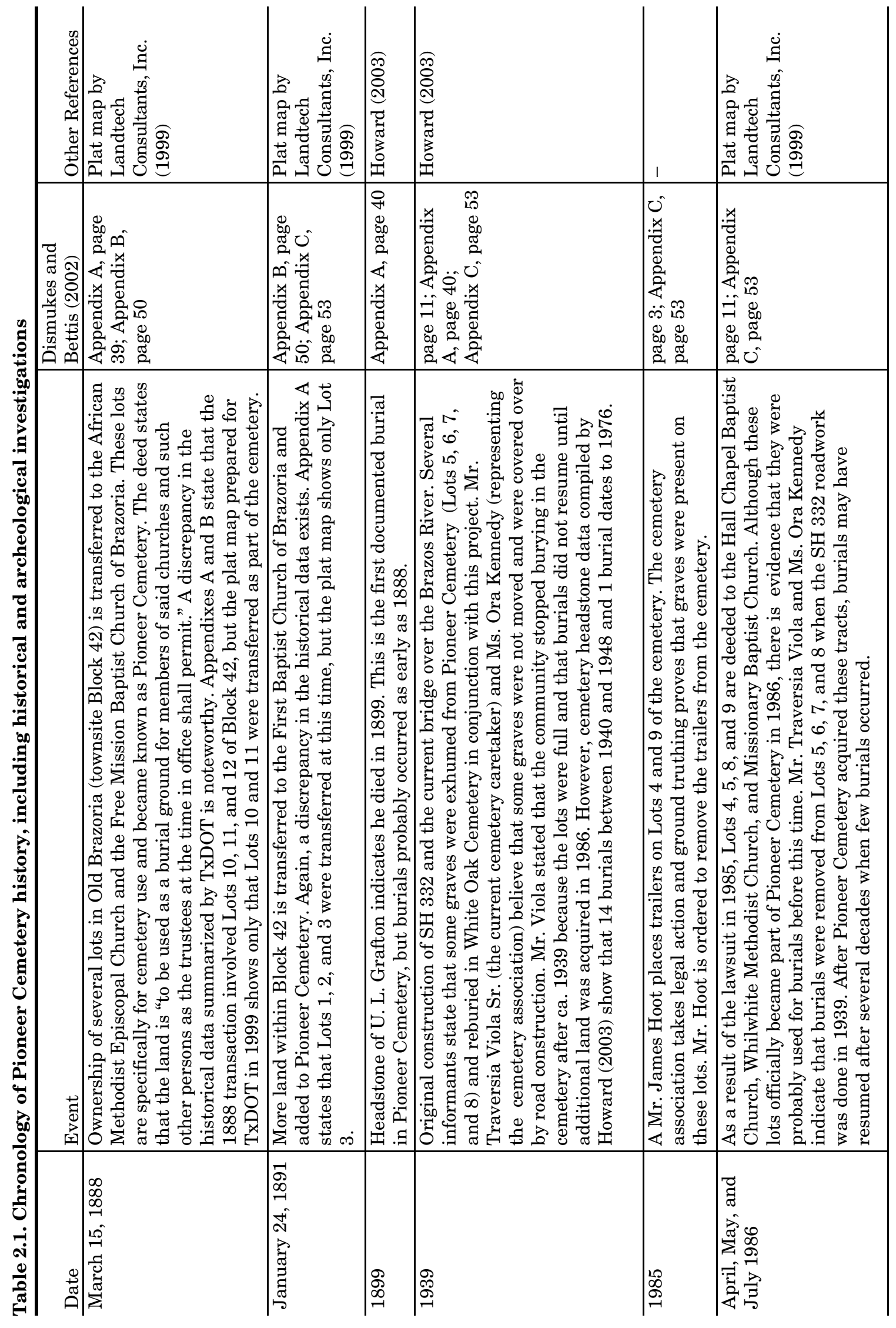


Chapter 2: Historic Background

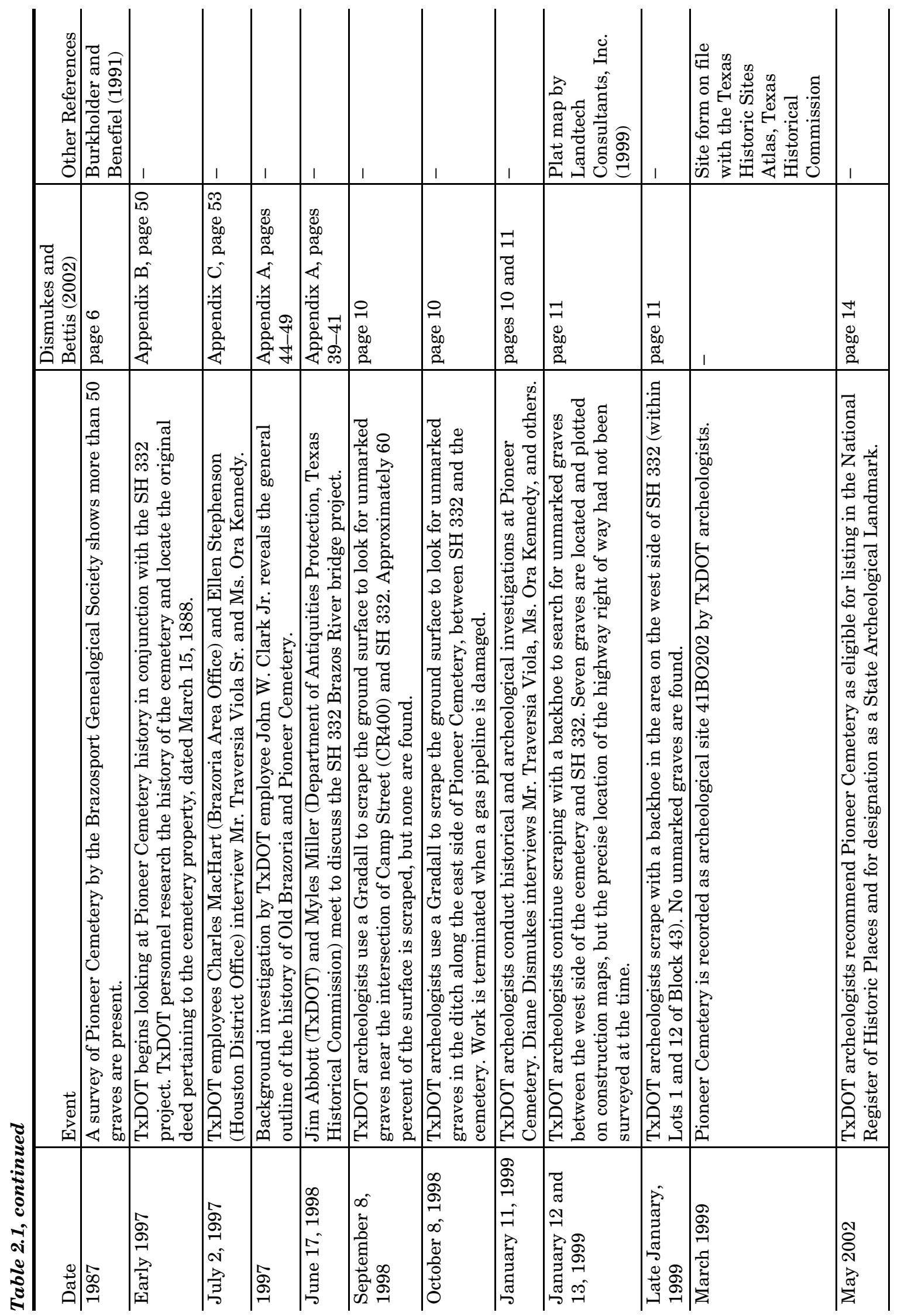


Excavation and Reburial of Unmarked Historic Graves in the Pioneer Cemetery

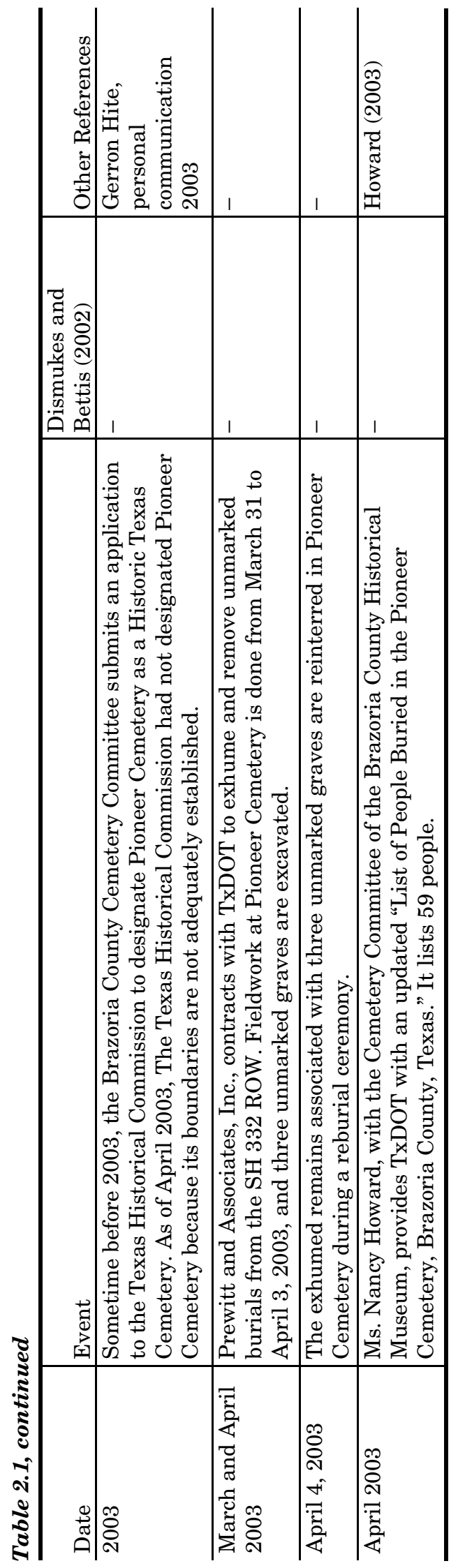




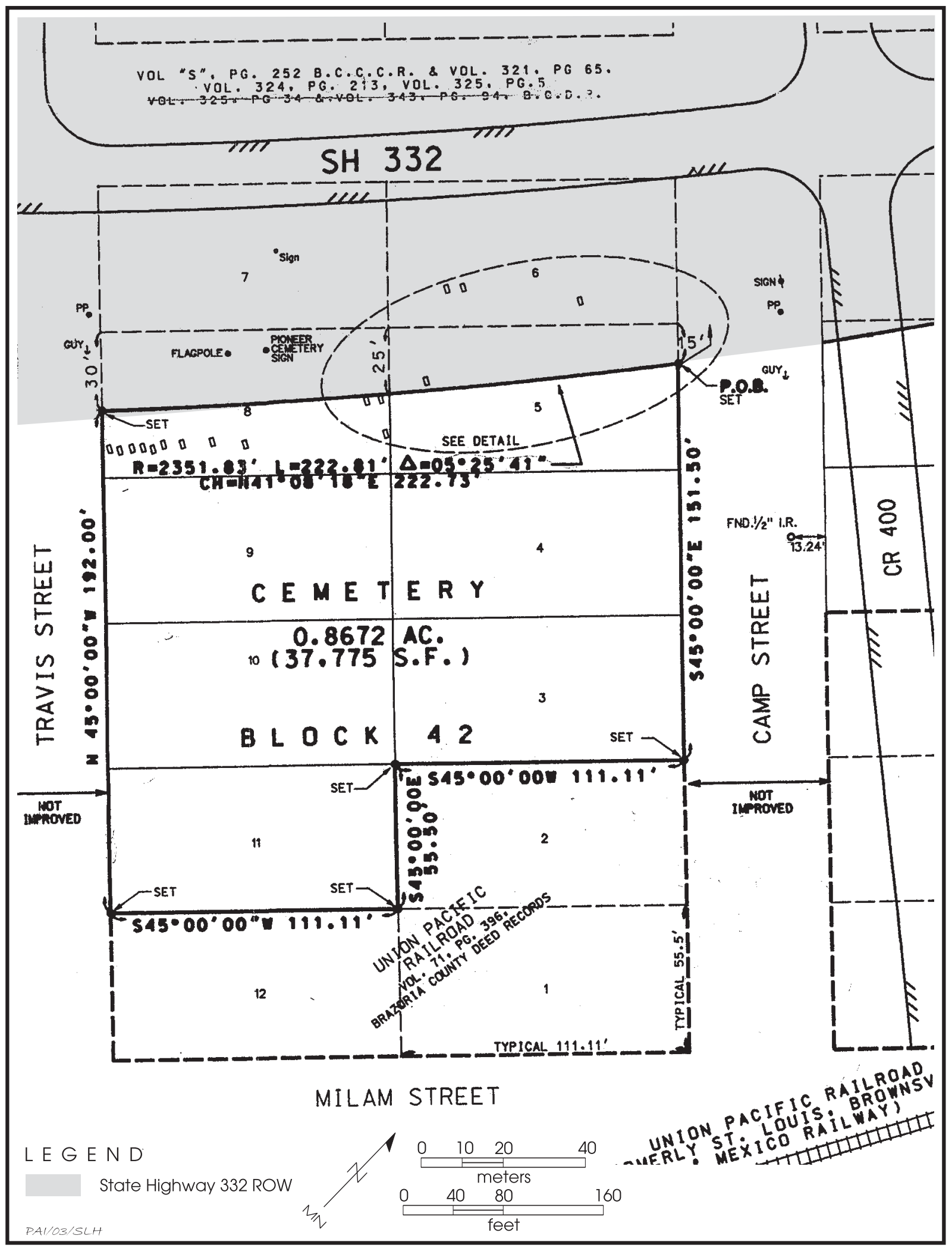

Figure 2.1. Plat map showing Pioneer Cemetery and lots within Brazoria townsite Block 42. Map also shows the locations of seven "unmarked graves" (within the dashed oval) found by TxDOT archeologists in 1999. Map is from Landtech Consultants, Inc. (1999), and was reproduced in Dismukes and Bettis (2002:Figure 26). 



\section{METHODS OF INVESTIGATION}

Prior to beginning the work at Pioneer Cemetery, PAI archeologists prepared a scope of work and submitted an application for a Texas Antiquities Permit. Prefield planning involved contacting the cemetery caretaker and local community members to schedule the work. Arrangements were made to rent a backhoe and operator from M\&E Brazos, a local excavation contractor. Because the project would involve mechanical excavations, PAI notified the OneCall Board of Texas. They responded with information about buried utilities in the SH 332 ROW. Prewitt and Associates contacted City of Brazoria Public Works Superintendent David Jordan, and he marked the locations of buried utilities that were near the planned excavation areas. In particular, a buried gas line was present near two of the unmarked grave locations, and Mr. Jordan was present at all times when the backhoe was excavating in this area.

The other major safety concern was that the excavations were within the City of Brazoria, adjacent to heavily traveled SH 332 . The excavation work was far enough from the existing roads so that no traffic barriers were needed, but the highly visible project attracted many visitors and curious people. Consequently, people had to be reminded to park vehicles safely away from the road, and the excavations had to be barricaded with orange mesh fencing to keep people at a safe distance from the trenches.

Field investigations at Pioneer Cemetery included several different tasks accomplished over a 5-day period. The first day was devoted solely to using a backhoe to re-locate the unmarked graves within the SH 332 ROW and re-expose the grave shafts. The second, third, and fourth days were devoted primarily to hand excavation of three burials, field laboratory analysis of the human skeletal remains, and documentation of all material remains. The human remains and associated funerary materials were placed into reburial containers and stored temporarily until the end of the project. On the fifth day in the field, PAI archeologists assisted the local community in conducting a ceremony during which the three excavated burials were reinterred. Each of these tasks is discussed in more detail below.

\section{RE-LOCATION OF UNMARKED GRAVES}

The first step in burial removal was to identify the locations of the six graves previously identified within or near the construction ROW during the 1999 TxDOT investigations (Figure 3.1). Burial locations were estimated by triangulating measurements from a map generated by TxDOT of the plotted graves (see Dismukes and Bettis 2002:Figure 26). After the approximate location of each grave was marked on the surface with a nail and flagging tape, a backhoe was used to excavate each area. The mechanical digging continued until the plastic sheeting and pin flags placed by the previous investigators were located. The backhoe was used to remove all overburden from the top of the plastic sheeting and clear an area large enough to permit the excavators to work safely. The six unmarked graves were designated Burials 1-6 by PAI archeologists, in ascending order from north to south. These numbers correspond to TxDOT's designations (Graves 1-6).

During the previous investigations, archeologists identified a disturbance in a trench wall several meters southwest of the first burial 


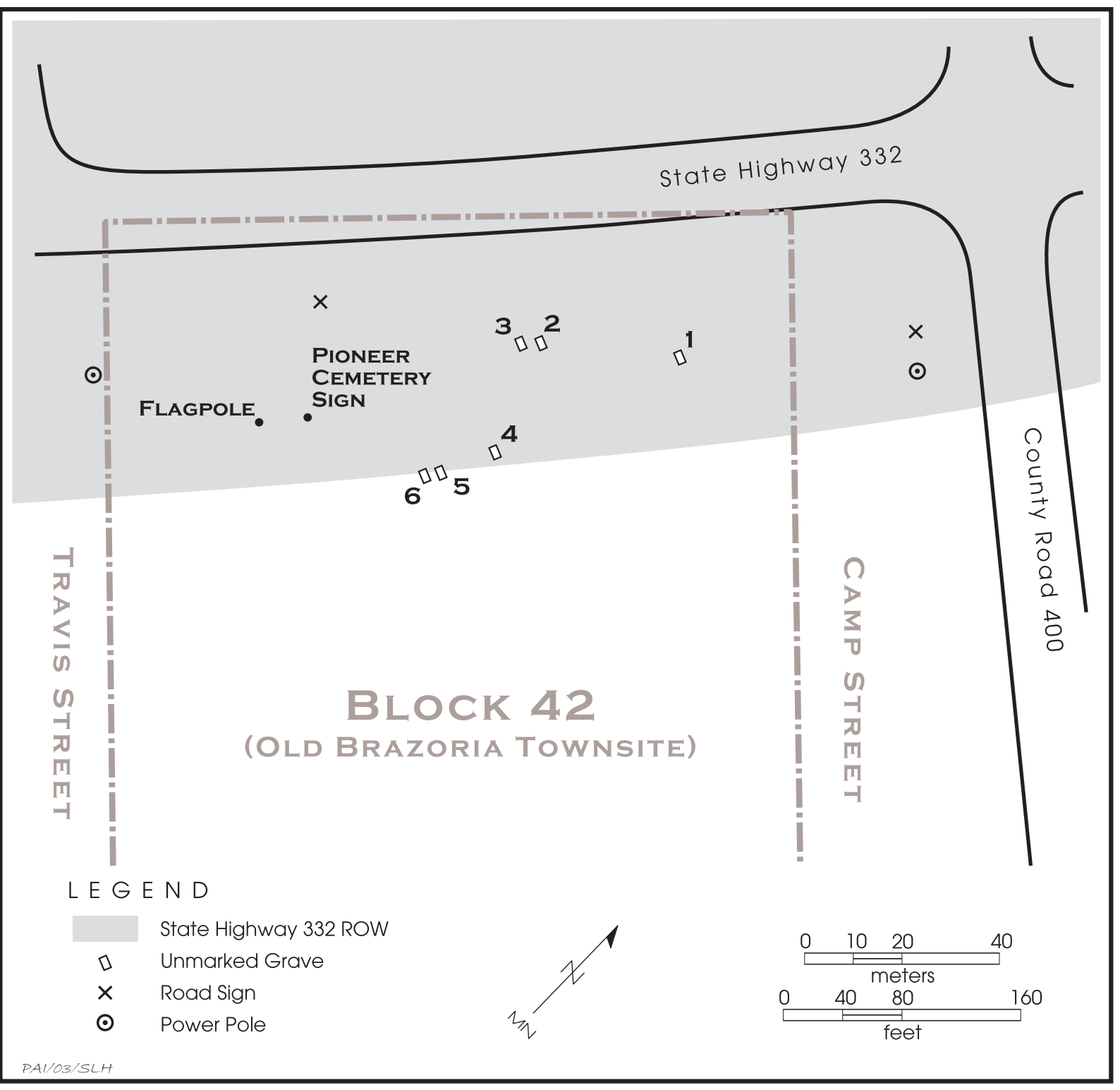

Figure 3.1. Unmarked graves within TxDOT's State Highway 332 ROW. Map is from Landtech Consultants, Inc. (1999) and was reproduced in Dismukes and Bettis (2002:Figure 26).

encountered at the northern end of the proposed ROW (Dismukes and Bettis 2002). Its proximity to a ditch and gas line parallel to the trench precluded extensive investigation, and the stain was tentatively designated Grave 2. Its status as a burial was left to be determined should removal be warranted. Extensive backhoe scraping during the current investigations in the vicinity of the reported stain indicated that no burial was present. The burials were not renumbered, however, and the feature called Burial 2 was probably a natural phenomenon such as a tree root stain.

The two southernmost burials, Burials 5 and 6 , were found to be mostly outside the construction ROW. As fewer than $40 \mathrm{~cm}$ of the west ends of the burials crossed into the ROW, it was agreed upon by TxDOT archeologists and cemetery preservationists that these two graves should remain undisturbed. The portions of the burials exposed by trenching were capped with concrete to protect them and make them identifiable during the planned road construction. The following information was etched in the concrete 
at the head of each grave: "UNKNOWN GRAVE/ TxDOT/ April 2003" with an arrow drawn in the direction of the remainder of the burial (Figure 3.2). Two upright metal posts were embedded in the concrete to mark the burial locations above ground to make sure they are protected during construction.

\section{BURIAL EXCAVATIONS}

After the burials were located, it was essential to confirm the exact location of the highway ROW. Mr. Jarrett L. Hamilton, a TxDOT engineering technician with the Brazoria Area Engineer's Office, marked the precise ROW location near several of the burials. It was then determined that only three graves (Burials 1, 3 , and 4) were completely within the ROW and required removal. Two other graves (Burials 5 and 6) were found to straddle the ROW line, and a decision was made to leave them in place.

Once located with the backhoe, each of these burial shafts was gradually scraped in thin 2 5-cm (1-2-inch) layers with a backhoe until wood from the burial container was encountered. After the overburden had been removed from all the graves, mechanical activities ceased and exposure of burials proceeded by hand. Generally, once a grave outline was defined, two field crew members excavated the grave with small hand tools, brushes, and bamboo skewers (Figure 3.3). Due to the small size of the subadult, a single excavator was assigned to the Burial 4 excavation.

A variation of the excavation method used by the Arkansas Archeological Survey at the Cedar Grove Cemetery (Rose 1985) was employed in which five separate areas of the skeleton or burial container were designated and served as a reference for artifact location. The five zones consist of the cranial, upper left, upper right, lower left, and lower right areas. Upper and lower were defined as being above, or below, the iliac crest of the pelvis. Skeletal elements or segments were bagged individually and labeled according to anatomical location. In instances where skeletal elements were embedded in the wall or floor of the burial, they were removed

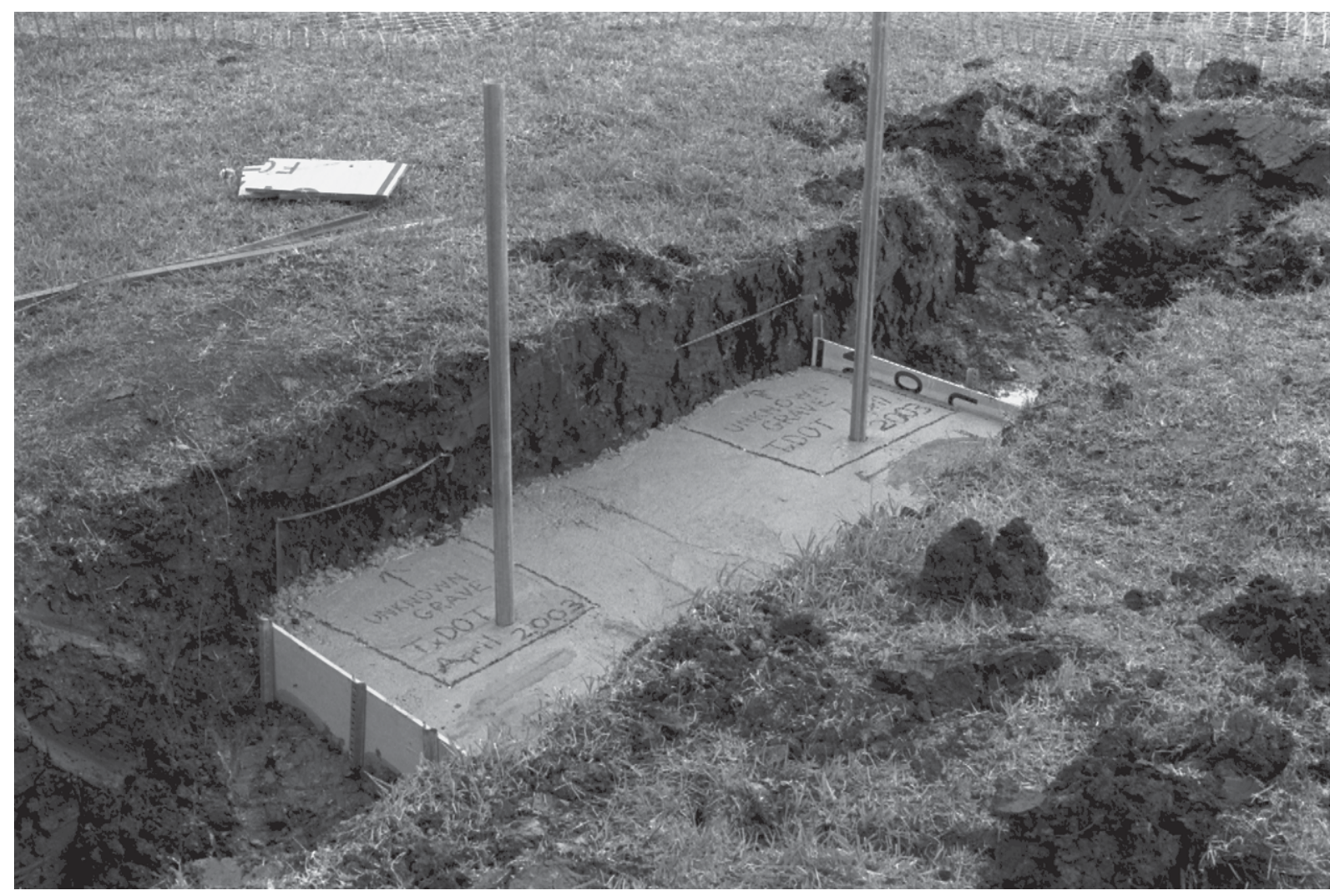

Figure 3.2. Overview of Burials 5 and 6 showing concrete cap over the west ends of the grave shafts. 


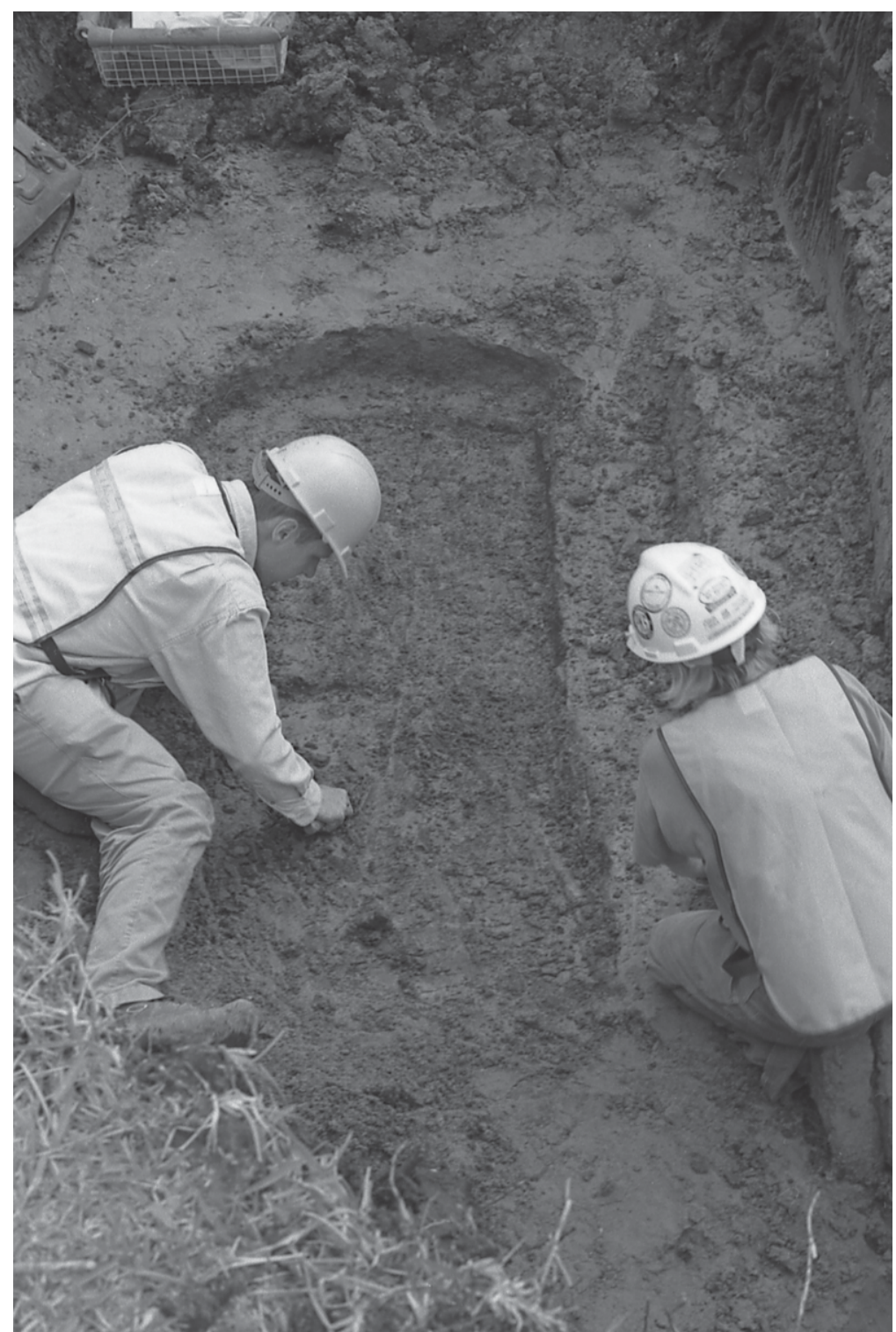

Figure 3.3. Hand excavation of Burial 1, looking west. ervation, all of the coffin fill dirt from Burial 4 was removed and hand-excavated in the field laboratory to maximize recovery.

Field documentation of the graves involved black-andwhite and color photographs of the full, exposed skeleton and burial container, as well as close-up photographs of segments of the exposed burialusually the cranial, thorax, pelvic and upper leg, and lower leg and foot areas. In addition, each excavation team filled out a burial excavation form (Appendix B). Information collected included soil color and consistency; burial orientation; below surface depth of the burial container; dimensions of the burial container; container shape and material; presence and location of associated artifacts; disposition, condition, and position of the skeletal remains; and any other noteworthy features (e.g., color of burial container). A scaled diagram of each burial was drawn to show the spatial relationships between the burial container, the skeleton, and artifacts. Excavators also made notes on any disturbances that were observed.

Because of the sensitive nature of the project and public setting, the burial excavation areas were barricaded so people

with the matrix in small blocks to be further investigated in the field laboratory. Artifacts were bagged and labeled by excavation zone.

Skeletal preservation ranged from poor to good. The adult bones in Burials 1 and 3 were generally well preserved, but the child's remains in Burial 4 were poorly preserved. Only limited amounts of bone were preserved in this burial, although "ghosts" of dust from a few long bones were identifiable. Teeth and fragments of the petrous portion of the temporal were the only human remains intact enough to be recovered from this burial. Due to the extremely poor pres- could not get close to the graves. The excavations were scheduled so that remains were left exposed for as little time as possible. When the disinterment of each burial was completed, the remains and associated materials were removed from the grave by hand and transferred to a wooden reburial container, and each box was discretely labeled with the burial number. The reburial boxes provided by TxDOT were made of pine wood, and each one measured 2 feet long, 1 foot wide, and 1 foot tall.

After removal of the three burials, the backhoe and a small bulldozer were used to backfill 
the excavations. Because it had rained heavily just before the fieldwork began, the clay soils were saturated and the heavy machinery used for backfilling left deep ruts in some places. Consequently, two truck loads of sand were purchased, dumped, and spread over the area to restore the ground surface.

\section{BIOARCHEOLOGICAL EXAMINATIONS}

The project scope required that the remains and artifacts be reburied within the cemetery immediately after excavation and analysis. Following their removal, the human bones and associated material remains were processed and analyzed in an on-site laboratory that consisted of a large tent and several large work tables. Due to the high water table in the project area, burial materials were often extremely muddy and required cleaning prior to analysis. When necessary, bones and artifacts were washed with water and then dried thoroughly. Teeth and alveolar bone were cleaned with a 50/50 mixture of water and isopropyl alcohol. Skeletal elements removed in blocks of dirt were soaked in a calcium bicarbonate (baking soda) solution to separate them from the clayey matrix. The analysis process included cleaning the bones and artifacts, osteological examination of the human remains, analysis of the funerary hardware and other grave goods, and photographic recordation of the human remains and artifacts. Artifacts were also sketched on standardized forms (see Appendix B).

\section{Skeletal Analysis}

Skeletal analyses followed the guidelines established in Standards for Data Collection from Human Skeletal Remains (Buikstra and Ubelaker 1994). Osteological observations included inventory of skeletal elements, sex assessment, age estimation, skeletal metrics, skeletal nonmetrics, and pathological observations (Appendixes $\mathrm{C}$ and D). Inventory was recorded in numerical code according to the completeness of the bone or portion of the bone. Sex was estimated osteologically only for adults because most skeletal features (particularly those that preserve well) that distinguish males from females do not manifest osteologically until puberty. Adult sex was determined on the basis of pelvic and cranial morphology and skeletal robusticity (see discussions in Angel 1969; Bass 1995; Houghton 1974, 1975; Krogman and Iscan 1986; Stewart 1979; Ubelaker 1989; and Ullrich 1975). Associated artifacts were sometimes helpful in assessing sex, although they were not considered a definitive indicator of sex.

Metrical indicators of sex were generally utilized as a supplement to the pelvic indicators. Although they offer the advantage of providing quantifiable data, measurements are generally less reliable indicators of sex than pelvic morphology because they are not directly related to reproductive functioning (i.e., women typically have wider hips to facilitate childbirth), the primary criterion for sex distinction in the field of biology and in most cultures. Also, sex differences in size and robusticity are population specific. Poor skeletal preservation limited metrical analysis to univariate discriminant functions, usually the maximum diameter of the femoral head (Stewart 1979:120) and certain measurements of the tibia (Symes and Jantz 1983). In the instance of these two referenced metrical studies, data were derived from skeletal collections composed of individuals from roughly the same time period as the recovered burials, and many were poor or indigent. The Symes and Jantz standards are based on American Blacks, whereas Stewart's results were derived from a mixed racial sample. Both are considered an acceptable reference for the Pioneer Cemetery skeletal sample.

Cranial suture closure (Meindl and Lovejoy 1985), dental attrition, and skeletal joint degeneration served as general indicators of adult age, while techniques for observing the morphological changes to the auricular surface (Buckberry and Chamberlain 2002; Lovejoy et al. 1985) and pubic symphysis were utilized (Brooks and Suchey 1990; Katz and Suchey 1986; Todd 1920, 1921) for more precise age determination when skeletal preservation permitted. Epiphyseal union (Bass 1995; Brothwell 1981; Webb and Suchey 1985) permitted age assessment for subadults and young adults. Subadult age was derived from stages of dental development and eruption (Lunt and Law 1974; Moorrees et al. 1963; Schour and Massler 1941; Ubelaker 1989).

Skeletal measurements were taken in accordance with guidelines established by MooreJansen and Jantz (1989). Nonmetric skeletal 
observations and pathological observations were recorded in numerical code. Pathological conditions were also described in narrative form and plotted on skeletal diagrams. When possible, ethnicity was assessed from morphological observations of the facial bones (see Bass 1995; Rhine 1990; Stewart 1979; Ubelaker 1989) and femora (Stewart 1979; Ubelaker 1989).

Dental data were also collected according to Buikstra and Ubelaker's (1994) guidelines. Data were collected through macroscopic observation. Dental inventory, including premortem and postmortem tooth loss; development/eruption; location and degree of calculus deposits; presence and location of all observable caries and abscesses; degree of attrition; and the presence of enamel hypoplasias were documented both numerically and visually. Enamel hypoplasias were documented according to presence, type, and location (i.e., measured distance from the defect to the cemento-enamel junction). Premortem damage or modification was both described in narrative form and plotted on a diagram. Dental measurements and morphological observations were omitted from this study due to time constraints.

All pathological and anomalous dental and skeletal conditions were recorded on film as were skeletal features diagnostic of age or sex. All images were taken on black-and-white film unless only color film could properly document the desired attribute. Color slides were also taken of all good examples of certain skeletal and dental features (e.g., pathological lesions, unusual dental wear).

\section{Artifact Analysis}

The artifacts found in association with the remains were examined and documented on an artifact identification form (see Appendix B). Data concerning artifact type, material, dimensions (measured with metric digital or dial calipers), manufacture style, and location in the grave were recorded. Each unique artifact or a representative example of a group of similar artifacts were documented through sketches, notes, and photographs. Following the fieldwork, antique collector's guides and trade catalogs were consulted to determine relative date of availability and affordability of various items.

\section{PUBLIC INVOLVEMENT AND REBURIAL}

The Pioneer Cemetery project drew lots of public attention, and there were many visitors to the site while work was in progress. For safety reasons and out of respect for the buried persons and their descendants, the excavations and the field laboratory were barricaded and kept off limits to casual visitors. Visitors were not allowed to view the human skeletal remains, either in the ground or in the field laboratory. Throughout the project, there was a great deal of interest among the members of the cemetery committee of the Brazoria County Historical Museum and people whose relatives are buried in Pioneer Cemetery. Many of the cemetery committee members helped PAI archeologists with such tasks as setting up and moving barricades.

Several reporters and photographers visited the site during the field phase, and TxDOT archeologists handled most of the public relations with the media. At least two articles appeared in newspapers while the fieldwork was in progress. Velda Hunter wrote "Workers Begin Moving Graves: Historic Burial Sites Making Way for New Bridge into Brazoria," an article that appeared in the April 1, 2003 edition of The Facts (local paper published in Brazoria). Richard Stewart wrote an article entitled, "Names Still a Mystery as Remains are Reburied," that appeared in the April 4, 2003 edition of the Houston Chronicle.

Archeologists from PAI and TxDOT assisted the local community with the reburial planning and the ceremony. Various parties were consulted to determine where the exhumed burials would be reinterred within Pioneer Cemetery. There were several discussions between the archeologists, members of the BCHS cemetery committee, Ms. Ora May Kennedy (representative of the Pioneer Cemetery Association), and Mr. Traversia Viola (the cemetery caretaker and representative of the Pioneer Cemetery Association). Finally, it was decided that an area just west of where Burial 4 was exhumed would be the best reburial location. The area was selected because it was completely inside the cemetery property $(60 \mathrm{~cm}[23.6$ inches] east of the SH 332 ROW line) and no grave shafts were found when the excavation was expanded around Burial 4. No graves were located in an area about $100 \mathrm{~cm}$ [39.4 inches] 
east of where Burial 4 was found, and the area was large enough to accommodate the reburial. The area had been backfilled, but a backhoe was used to re-excavate a trench the morning of the reinterment. The reburial trench was $3.0 \mathrm{~m}$ long (north-south) by $1.5 \mathrm{~m}$ wide (east-west) and just over $1.0 \mathrm{~m}$ deep $(9.8 \times 4.9 \mathrm{ft}$; $0.3 \mathrm{ft}$ deep). All three of the reburial boxes were placed, side by side, inside this trench. On the day of the reburial ceremony, all of the PAI archeologists who participated in the burial excavations were present, as were TxDOT archeologist Allen Bettis Jr. (ENV) and Brazoria area engineer Larry Heckthorn. The ceremony is discussed in more detail in Chapter 7.

\section{CURATION OF MATERIALS}

Following analyses and documentation, all human remains and associated artifacts were reinterred within the selected area of Pioneer Cemetery, just beyond the highway ROW. All field and laboratory records and maps were prepared for curation and placed in archival-quality containers. Field notes, burial forms, photographs, and other data gathered during these investigations will be curated, at least temporarily, at the Archeological Studies Program offices of the Environmental Division, Texas Department of Transportation, Austin, Texas. 



\section{BURIAL DESCRIPTIONS}

The following chapter presents the descriptive information for each of the three excavated burials: Burials 1, 3, and 4. The other three burials are discussed here only briefly because Burial 2 was determined to be a natural feature, and Burials 5 and 6 were identified but not excavated. Data for the excavated burials consists of details about burial depth, orientation, and body position; an inventory of artifacts; an osteological inventory; demographic and pathological information; a dental inventory; and data for dental pathology, anomalies, and modifications.

\section{TERMINOLOGY}

Burial depth refers to the depth from the ground surface measured from a level string line to the bottom of the burial container. In the following discussion, skeletal preservation is defined as follows:

- excellent: skeleton complete and fully intact

- good: skeleton more than 75 percent complete, with most bones, particularly long bone shafts, intact

- fair: skeleton 25-75 percent complete or fragmented or deteriorated

- poor: less than 25 percent of skeleton present or highly fragmented or deteriorated

Dental terminology used to describe specific teeth in the descriptions are represented by the following:

- C: canine; I: incisor; M: molar; P: premolar
- Capital letters: permanent teeth

- Lowercase letters: deciduous teeth

- Superscripted numbers: upper (maxillary) tooth number

- Subscripted numbers: lower (mandibular) tooth number

- Superscripted x: upper (maxillary) canine

- Subscripted x: lower (mandibular) canine

\section{BURIAL DESCRIPTIONS}

\section{Burial 1}

Burial Shaft Size and Depth: The grave shaft measured $197 \times 56 \mathrm{~cm}(77.6 \times 22.0$ inches), and the bottom was $163 \mathrm{~cm}$ (64.2 inches) below the surface.

Burial Orientation: E-W; head to west

Coffin/Casket Description: The coffin was a wooden, 4-sided burial container with the long sides tapered toward the feet. It measured $194 \mathrm{~cm}$ (76.4 inches) in length, and its width ranged from $55 \mathrm{~cm}$ (21.7 inches) at the head end to $35 \mathrm{~cm}$ (13.8 inches) at the foot end. The wood was identified by Phil Dering (personal communication 2003) as hard pine.

Coffin / Casket Hardware: Four white metal coffin screws, two white metal ornamental dummy tacks, six iron tacks, 89 machine-cut nails and nail fragments.

Personal Items: One white porcelain button was recovered from the left side of the individual at the level of the pelvis. 
Unassociated Artifacts: A lid from a hinged metal toolbox was located at the west end of the grave above the coffin. The rectangular lid measured $66 \times 22 \mathrm{~cm}(26.0 \times 8.7$ inches $)$ and is $1.5 \mathrm{~cm}$ (0.6 inches) thick. It was found in January 1999, when Burial 1 was initially discovered. The investigators (Dismukes and Bettis 2002:Figure 25) state that the toolbox lid "was perfectly aligned with the grave and may have served at one time as a marker for the grave..."

Burial Position / Taphonomy: The individual was probably originally in an extended position; however, much of the skeleton was disarticulated. Fluctuations in the water table caused the grave shaft to fill with water overnight during excavation, and this appears to have occurred within the grave and coffin numerous times. As a result, various bones had floated from their original positions and settled elsewhere. Most elements had shifted to the north side of the grave, except the right arm bones and right tibia and fibula, which remained in the south side. However, the arm bones were scattered, and the distal ends of the lower leg were oriented proximally. Several elements from the left side of the body were embedded in the north wall of the grave. The skull was lodged in the northwest corner with the mandible and maxilla in the north wall. Several vertebrae were piled in the lumbar region, although others were isolated in various parts of the upper body. The arm and hand bones were scattered in the chest region making determination of the original arm positions impossible.

\section{Skeletal Preservation: Good}

Sex: Female

Age: $17-23$ years

Skeletal Inventory: Nearly complete skull and mandible; both clavicles; partial scapulae; manubrium; sternal body; nearly complete vertebral column and ribs; partial left and right ilia, auricular surfaces present but eroded; left and right ischia; right pubis; diaphysis, distal epiphysis, and partial proximal epiphysis of left humerus; diaphysis and partial proximal epiphysis of right humerus; left radius, missing distal epiphysis; right radius; left ulna, missing distal epiphysis; right ulna; left femur with distal epiphysis fragments; right femur, missing distal epiphysis; both patellae; left tibia, missing distal epiphysis; right tibial diaphysis; left and right fibulae, missing proximal epiphyses; most hand and foot elements.

Infection: None observed

Degenerative Pathology: None observed

Trauma: None observed

Metabolic/Hematological Pathology: None observed

Neoplasm: None observed

Enthesopathy: None observed

Skeletal Anomalies: None observed

Dental Inventory: Complete permanent dentition except for postmortem loss of right $\mathrm{P}_{2}$.

Dental Pathology: One carious lesion each on the occlusal surfaces of right $\mathrm{M}^{1}$ and left $\mathrm{M}^{2}$; three hypoplastic lines on each $\mathrm{I}^{1}$; one hypoplastic line on each mandibular incisor.

\section{Dental Anomalies / Modifications: None observed}

\section{Burial 2}

Burial 2 was identified as a soil stain in 1999 , but was determined to be a natural feature. Dismukes and Bettis (2002:11) reported that, "An additional disturbance, recorded as Grave \#2, may or may not ultimately be shown to be a grave. Only the smallest soil disturbance was seen in the side-wall as the trench was excavated." Further excavations were not done at that time because the feature was located close to a buried gas line. Careful monitoring of backhoe excavations in this area in 2003, along with hand excavations in the immediate vicinity of the buried gas line, failed to reveal any further evidence of a grave shaft. In all likelihood, the feature observed in 1999 was probably a tree root disturbance. Similar features were observed in several areas during the backhoe trenching in 2003. 


\section{Burial 3}

Burial Shaft Size and Depth: The grave shaft measured $213 \times 80 \mathrm{~cm}(83.9 \times 31.5$ inches $)$, and the bottom was $173 \mathrm{~cm}$ (68.1 inches) below the surface.

Burial Orientation: E-W; head to west

Coffin/Casket Description: A rectangular wooden casket was present within a rectangular wooden outer box. The wood from the outer box and inner casket were melded together, and it was not possible to give accurate measurements of the casket. The outer box measured $211 \times 78 \mathrm{~cm}$ (83.1x30.7 inches). The wood was identified by Phil Dering (personal communication, 2003) as hard pine.

Coffin / Casket Hardware: 17 white metal ornamental dummy tacks; 4 iron screws; 11 machinecut nails.

Personal Items: Three bakelite or hard rubber hairpins were recovered from the head and neck region. One gold-plated metal hair barrette with an ornate floral design was beneath the occipital. Two small gold metal hoop earrings were present in the cranial area. Twelve identical medium-sized white porcelain buttons and one large white porcelain button were recovered from the torso. The matching buttons appear to have originally been arranged in two vertical rows. A gold ring was recovered from a cluster of hand elements over the abdominal region. Because these small bones were jumbled, it is not certain on which hand the ring was worn.

Unassociated Artifacts: Two pieces of oyster shell were recovered from burial shaft fill.

Burial Position/Taphonomy: The individual was supine, in an extended position with the head to the west. The arms were folded over the abdomen. Although the top of the skull is facing west, the cranial area was slightly disturbed. The mandible was to the left of the skull with the mental eminence facing west, and face position was indeterminate. Most of the bones were stained black.

Skeletal Preservation: Fair
Sex: Female

Age: $45-60$ years

Skeletal Inventory: Nearly complete calvarium and mandible; both zygomatics; partial maxillae; left clavicle; partial scapulae; iliac fragments, including partial left and right auricular surfaces; miscellaneous rib and vertebral fragments, including atlas and centra from the axis and seventh cervical vertebra; left humerus; right humerus with partial proximal epiphysis; left radius; fragments of proximal $1 / 2$ of right radius; proximal 2/3 of left ulna; fragments of distal 1/2 of right ulna; proximal 2/3 of left femur with fragments of distal epiphysis; right femur, missing most of distal epiphysis; distal 1/2 of left tibia; both patellae; partial proximal epiphysis and distal $1 / 2$ of right tibial diaphysis; proximal $2 / 3$ of left fibular diaphysis; distal $2 / 3$ of right fibular diaphysis and partial distal epiphysis; incomplete hand and foot elements.

\section{Infection: None observed}

Degenerative Pathology: Mild to moderate osteophytosis of superior and inferior margins of $\mathrm{C} 7$ centrum with compression evident; mild ridging along medial margin of distal articular surface of left femur; thick elevated bony ridge along all of visible medial margin of posterior right patella, articular surfaces of both patellae are granular and becoming porous; pronounced, thick bony ridging along entire lateral margin of distal left tibia with pinpoint porosity along less than $1 / 4$ of the medial margin; mild bony ridging on posterior superior left talus.

\section{Trauma: None observed}

Metabolic / Hematological Pathology: Bony apposition along endocranial surface of frontal squamous with striated, undulating appearance and bony nodules, consistent with hyperostosis frontalis interna (HFI).

Neoplasm: None observed

Enthesopathy: None observed

Skeletal Anomalies: None observed

Dental Inventory: Right $\mathrm{I}^{1}, \mathrm{C}^{\mathrm{x}}, \mathrm{P}^{1}$, and $\mathrm{M}^{2}$; left 
$\mathrm{I}^{1}, \mathrm{I}^{2}, \mathrm{M}^{1}$, and $\mathrm{M}^{2}$; left $\mathrm{P}_{2}-\mathrm{M}_{3}$; right $\mathrm{P}_{2}-\mathrm{M}_{2}$

Dental Pathology: Antemortem loss of left $\mathrm{P}^{1}$; carious lesion on mesial right $\mathrm{P}^{1}$ and distal right $\mathrm{C}^{\mathrm{x}}$, one carious lesion each on lingual and distal surfaces of left $\mathrm{I}^{1}$; large carious lesion has destroyed most of mesial $\mathrm{I}^{2}$ crown; cervical carious lesion on distal left $\mathrm{M}_{1}$; hypoplastic line on right $\mathrm{P}^{1}$.

Dental Anomalies/Modifications: Left $\mathrm{M}_{3}$ impacted, all other M3s and sockets not observable; rounded horizontal grooves worn into the lingual surfaces of left and right maxillary central incisors; lateral incisors not observable.

\section{Burial 4}

Burial Shaft Size and Depth: The grave shaft measured $113 \times 50 \mathrm{~cm}(44.5 \times 19.7$ inches $)$, and the bottom was $173 \mathrm{~cm}$ (68.1 inches) below the surface.

\section{Burial Orientation: SE-NW; head to NW}

Coffin / Casket Description: Burial container was a hexagonal wooden coffin. It measured $98 \mathrm{~cm}$ (38.6 inches) in length, and its maximum width was $30 \mathrm{~cm}$ (11.8 inches) at the shoulder. The head end was $10 \mathrm{~cm}$ (4.0 inches) wide, while the foot end was $20 \mathrm{~cm}$ (7.9 inches) wide. The wood was identified by Phil Dering (personal communication, 2003) as hard pine.

Coffin / Casket Hardware: Five white metal ornamental dummy tacks; six small iron tacks; 79 machine-cut nails and nail fragments.

Personal Items: Three white porcelain buttons of different sizes were present in the neck and torso areas. A small triangular fragment of gray slate was recovered from the left torso region. It is uncertain whether this item was an intentional inclusion.

\section{Unassociated Artifacts: None observed}

Burial Position/Taphonomy: The skeletal remains were extremely poorly preserved and very little bone was visible. The burial appears to have been extended with the head to the west, but any other body positioning could not be determined.
Skeletal Preservation: Poor

Sex: Indeterminate

Age: 2-4 years

Skeletal Inventory: The petrous portions of both temporals were present, as well as some miscellaneous bone fragments. Most skeletal elements were completely deteriorated. Dust outlines of a few long bones, probably the left humerus and tibiae, were observable in situ.

Infection: Not observable

Degenerative Pathology: Not observable.

Trauma: Not observable

Metabolic / Hematological Pathology: Not observable

Neoplasm: Not observable

Enthesopathy: None observed

Skeletal Anomalies: Not observable

Dental Inventory: Right $\mathrm{I}^{1}, \mathrm{M}^{1}$; left $\mathrm{I}^{1}{ }^{-} \mathrm{C}^{\mathrm{x}}, \mathrm{M}^{1}$; left $\mathrm{I}_{1}-\mathrm{C}_{\mathrm{x}}, \mathrm{M}_{1}$; right $\mathrm{M}_{1}$; right $\mathrm{i}^{2}-\mathrm{m}^{2} ;$ left $\mathrm{i}^{1}, \mathrm{c}^{\mathrm{x}}-\mathrm{m}^{2} ;$ left $\mathrm{i}_{2}{ }_{2}, \mathrm{~m}_{2} ;$ right $\mathrm{i}_{2}, \mathrm{c}_{\mathrm{x}}, \mathrm{m}_{2}$

Dental Pathology: None observed

Dental Anomalies / Modifications: None observed

\section{Burials 5 and 6}

The grave shafts for Burials 5 and 6 were discovered in 1999, but Dismukes and Bettis (2002) do not provide any detailed descriptions of these features. The west ends of both grave shafts were re-located in a north-south backhoe trench in 2003. Once the precise TxDOT right of way was determined, the backhoe trench was expanded eastward so that its eastern edge was exactly on the right of way line. The trench exposed about $40 \mathrm{~cm}$ (15.7 inches) of the head ends of both graves at a depth of approximately $80 \mathrm{~cm}$ (31.5 inches) below the surface. A decision was made to leave these graves in place, and the west ends of both were 
covered with a protective slab of concrete that measures $3.0 \mathrm{~m}$ long (north-south) by $1.6 \mathrm{~m}$ wide (east-west) and is 15 to $30 \mathrm{~cm}$ thick $(9.8 \times 5.2 \mathrm{ft}$; 5.9 to 11.8 inches thick) (see Figure 3.1). 



\section{ARCHEOLOGICAL ANALYSIS}

The following chapter provides a detailed discussion of the material culture recovered with the human interments from Pioneer Cemetery. Although one objective is to establish dates for the individual interments, the primary goal is to examine if and how the social and economic status of these individuals is reflected through the burial program at this cemetery. This includes discussion of the social and cultural relevance of the associated burial materials and comparison with contemporaneous historic cemeteries in eastern Texas.

\section{GENERAL MORTUARY TRENDS OF THE LATE NINETEENTH CENTURY}

Pioneer Cemetery was established in 1888 after the property was acquired by the trustees of two African American churches to serve as a burial ground for parishioners (Dismukes and Bettis 2002:6, 46, 50). At this time in the United States, an interrelated series of changes in technology and ideology occurred. Technological advances allowed the inexpensive mass production of items along with improvements in the marketing and distribution of goods. Ideologically, Romanticism was adopted into many aspects of American life, including death-referred to as the "beautification of death" movement (Bell 1990 ). By the 1850 s, American attitudes regarding death and burial began to change from that of gloom and formality to those that favored beauty and expressiveness. This change is reflected in the emergence of the mortuary industry and corresponding tremendous increase in varieties and elaborateness of burial receptacles and trimmings (Habenstein and Lamers 1995). Due to the paucity of recovered mortuary arti- facts, only the three trends relevant to this burial sample are discussed.

\section{Burial Containers}

During the latter half of the nineteenth century, the traditional hexagonal coffin was gradually replaced by the rectangular casket (a term originally used for a jewelry box), as the appearance of the coffin-which simulated the human outline-grew distasteful to many because of the morbid image it conveyed. An 1849 advertisement for Boston undertaker William Cooley that offered "Coffins, caskets, and robes of every description. . ." is the earliest known appearance in the United States of the casket as an alternative type of burial container. Yet, it was not until the period 1858-1862 when Crane, Breed \& Co. began to offer the straight-sided casket on a mass-produced basis (Habenstein and Lamers 1995:169). According to Lang (1984:46), the coffin became obsolete by 1927 . This change in burial receptacle shape is temporally significant only for larger, typically adult-sized, burial receptacles. Infants and small children were buried in rectangular containers much earlier (Davidson 2000). Nonetheless, by the last decades of the $1800 \mathrm{~s}$, more variety in color and casket materials (including wood, glass, and metal) became available for both child and adult burial containers (Habenstein and Lamers 1995).

During the nineteenth century, it was also a common burial practice to have some type of separation of the body and burial receptacle from the immediate grave environment (Habenstein and Lamers 1995). One method was vaulting. This practice entailed digging a hole approximately the size of the burial container 
into the bottom of a larger grave shaft, placing the coffin or casket in the smaller hole, and covering it by laying boards, slabs of sandstone, or any other available solid material across the opening (Condon et al. 1998; Craig and Larsen 1993; Davidson 2000; Fox 1984). By the latter half of the century, the burial receptacle was often placed in a wooden exterior container, which was a precursor to the metal and concrete burial liners used today. Originally, the outer box was merely the box the coffin or casket had been shipped in, and it was buried with the inner container as a means of disposal. However, finer, more visually appealing wooden outer boxes, which protected the coffin or casket from both the burial environment and would-be grave robbers, were manufactured and sold by the late $1870 \mathrm{~s}$ or early $1880 \mathrm{~s}$ (Habenstein and Lamers 1995).

\section{Lid Closures}

During the early half of the nineteenth century, coffin lids were typically secured with nails or screws, and for those who could afford them, coffin screws specifically designed for the purpose (Davidson 2000:238). These gimlet screws consisted of a slotted, knob-shaped cast white metal head attached to an iron shank (Figure 5.1). The head could be plain or decorated along the perimeter with a filigree design (HackerNorton and Trinkley 1984). Likewise, the head could be silver-plated or plain. Although it is known that they were manufactured and sold as early as 1853 , it is likely that they were produced for some time prior to this date (Davidson 2000:238). At this time, dummy screws (Figure 5.2), which consisted of the same slotted-white metal heads attached to a tack rather than a screw, were used both to create the illusion of additional coffin screws and as ornaments in their own right (Davidson 2000; Hacker-Norton and Trinkley 1984). Although offered by wholesalers and more regional companies up to the turn of the twentieth century, the coffin screw was gradually replaced by the thumbscrew (Figure 5.3). In most areas this occurred between the 1870 s and early 1880 s, and thumbscrews were being dropped from mainstream catalogs by this time. Davidson (2000) has identified three phases in the evolution of the thumbscrew in which it changes from closely resembling a coffin screw to a knob-like, urn-shaped fastener and, finally, to the broad, flat-bodied form that became the typical type. This latter form first appeared in catalogs in 1875 and

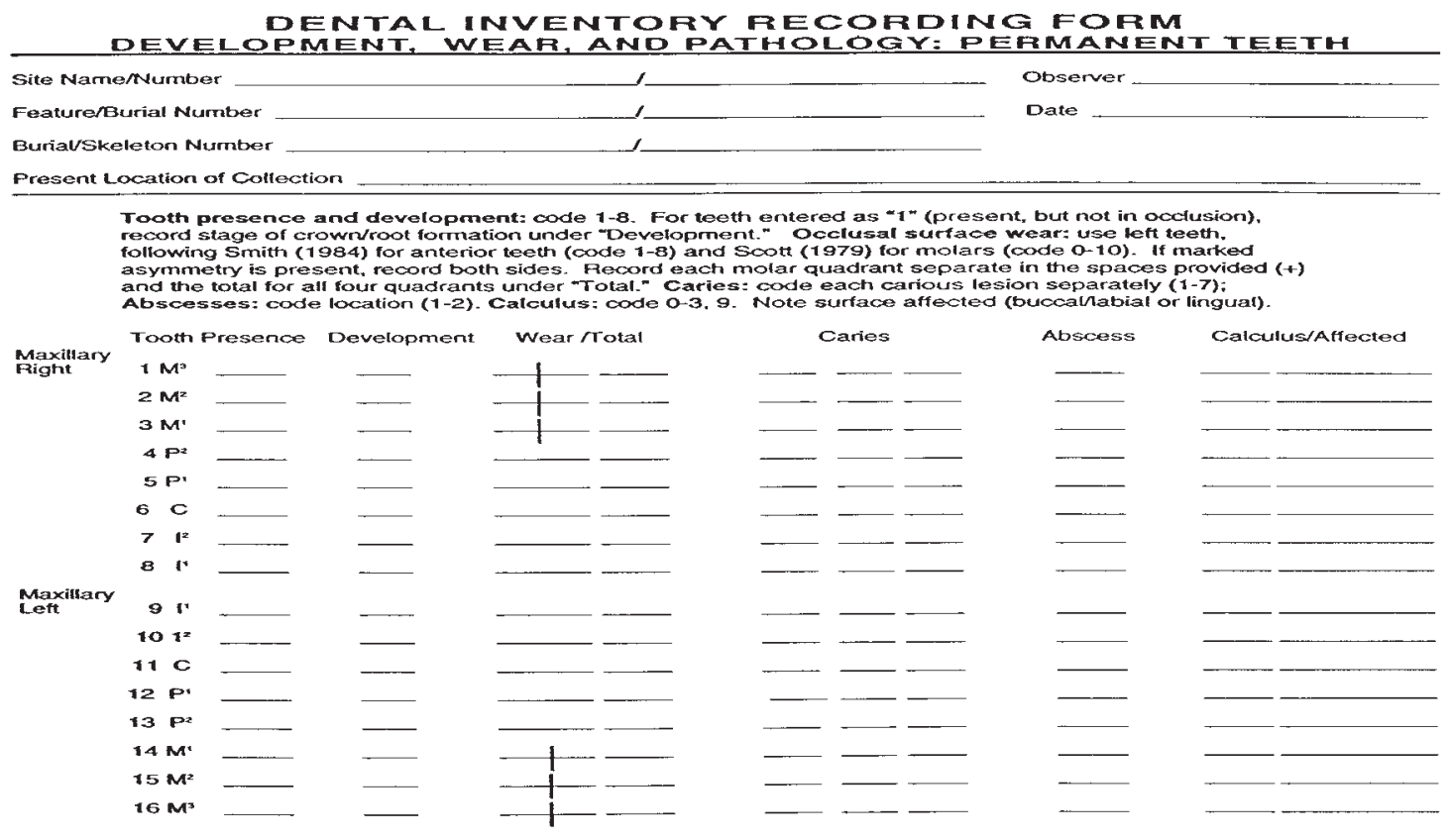

Figure 5.1. Examples of white metal coffin screws. Illustration is from an 1865 catalog of the Russell and Erwin Manufacturing Company (1980:332). 
Pine White Motal Coffin Paoka

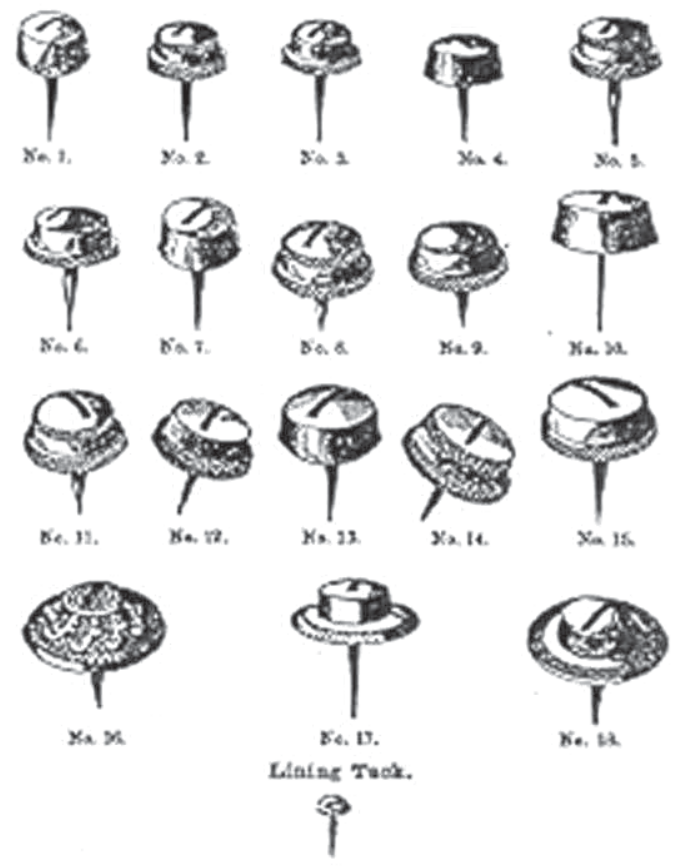

Figure 5.2. Examples of white metal coffin tacks. Illustration is from an 1865 catalog of the Russell and Erwin Manufacturing Company (1980:331).

was manufactured into the 1960s (Davidson 2000; Hacker-Norton and Trinkley 1984).

\section{Nails}

During the last few decades of the nineteenth century, the machine-cut nail was slowly replaced by the wire nail as the preferred type of construction fastener. Wire nails were first manufactured in France in the early nineteenth century and were made by hand in the United States as early as the 1850 s (Fontana and Greenleaf 1962:55; Nelson 1968). In 1879, the H. P. Nail Company of Cleveland, Ohio, began to successfully manufacture wire nails from Bessemer steel wire (Fontana and Greenleaf 1962:47). Wire nails became popular in the construction industry in the United States by the 1890s when they became relatively inexpensive (Nelson 1968) and were the predominant type by 1900 (Wells 1998). It is not known exactly when manufacturers switched from using machinecut nails to wire nails in the construction of coffins and caskets, although recent archeological investigations (e.g., Davidson 2000; Garrow and Symes 1987) suggest that wire nails were intro- duced into the mortuary industry by 1900 , but did not completely replace cut nails until after the turn of the twentieth century.

\section{ANALYSIS OF MORTUARY HARDWARE AND PERSONAL EFFECTS}

Items associated with the three burials excavated from Pioneer Cemetery were cleaned and identified as specifically as possible according to type, material, function, and style of design or manufacture. The artifacts consisted of two primary categories: mortuary artifacts-those related to the construction and ornamentation of the burial containers-and personal artifacts, which are items worn or otherwise possessed by the individual interred. A more-detailed artifact inventory is presented in Chapter 4. A third category included items that could not be confidently assigned to either category because they could be grave offerings or accidental inclusions.

Once the artifacts were identified, an attempt to establish date of interment for each burial
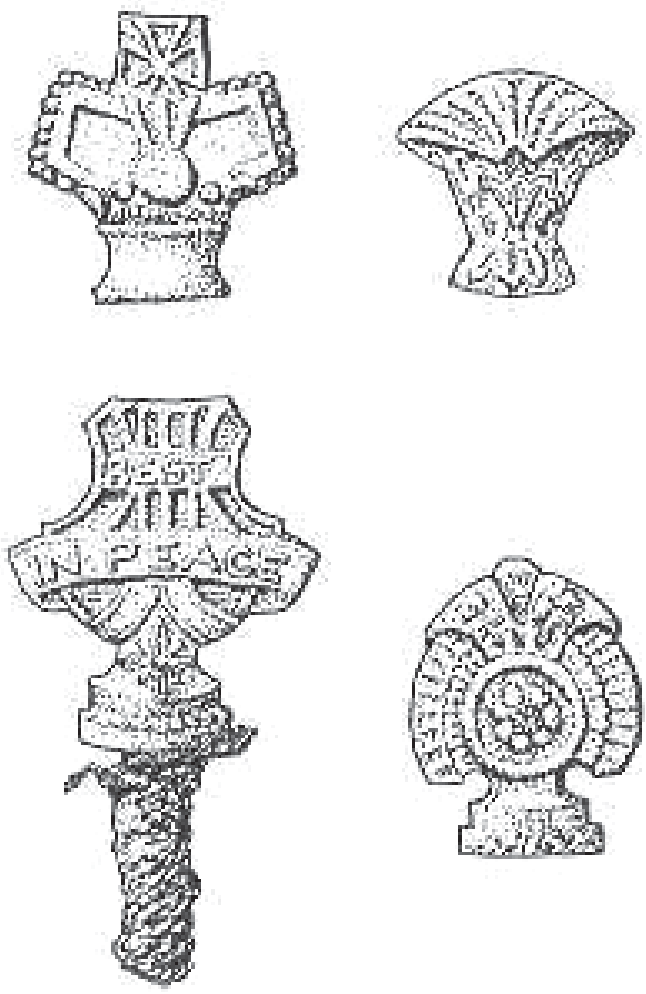

Figure 5.3. Examples of thumbscrews. Illustration is from Tiné et al. 2002:Figure 16). 
was undertaken. Manufacturing dates for the mortuary hardware were established based on knowledge of general trends in the mortuary industry and comparison with the general merchandise and hardware supply catalogs of the period. Similarly, manufacturing dates for personal items were derived from catalogs, as well as from literature related to the chronology of certain types of artifacts. Montgomery Ward and Company catalogs for 1894-95 and 1895 and Sears, Roebuck and Company catalogs for the years 1897, 1902, 1906, and 1927 were available for examination.

Estimation of interment dates is most effective when all artifacts from a single interment are considered together. Nonetheless, the dates given should be considered approximations rather than exact because other factors must be taken into account. Cost, local availability and popularity, individual taste, and the purchasing proclivities of local suppliers could have influenced the time period when particular items were available and used in a particular region. Also, for almost any item a lag period might have existed between when the item was patented and manufactured and when it was made available for sale.

\section{Interment Dates}

It was not possible to establish a narrow time frame for when the excavated burials were interred. The paucity of temporally diagnostic artifacts and their broad periods of manufacture are the primary reasons for this problem. Porcelain buttons, for example, were introduced many years before the founding of Pioneer Cemetery and were commonly used well into the twentieth century. Furthermore, although technological changes occurred, particularly in the funeral industry, these changes typically were not abrupt and the transitions could last several decades.

In the mortuary industry, coffins were gradually replaced by caskets in the late 1800 s, but both were available and used simultaneously into the early 1900s (Davidson 2000; Habenstein and Lamers 1995). Indeed, both types of burial containers were identified in the graves of the three excavated individuals. Burial 3 contained a rectangular casket, whereas the other two burial containers were variations of the coffin. Burial 4, was a traditional hexago- nal coffin, whereas Burial 1 was a 4-sided coffin with side boards that tapered toward the feet. As the headboard is noticeably wider than the foot board, this was a purposeful design (rather than distortion from the burial environment), but it is somewhat rare. Similar coffins have been observed in archeological contexts at two colonial period sites-St. Peter/Toulouse Cemetery in New Orleans, Louisiana (Owsley et al. 1985) and Martin's Hundred Settlement near Williamsburg, Virginia (Noël Hume 1983). One example of this type of coffin is from Phillips Memorial Cemetery in Galveston County, Texas, and is roughly contemporary with the Pioneer Cemetery burials (Dockall et al. 1996). Six interments from Matagorda Cemetery in Matagorda, Texas, date approximately to the middle of the nineteenth century and contained this form of coffin (Alston Thoms, personal communication 2001). Burial containers from a few graves at Cedar Grove Cemetery in southwest Arkansas date to the turn of the twentieth century and are described as either tapered toward the head or tapered toward the feet (Rose ed. 1985). It is uncertain whether the shape of these coffins reflects preservation factors that obscured the entire coffin outline or if they were, indeed, constructed in this manner. Davidson (2000:245) has suggested that this "tapered to the feet" style of burial container was probably a variation that tried to mimic the hexagonal coffin but could be made by coffin makers with limited carpentry skills.

In addition to the older style burial containers in two of the graves, the mortuary hardware recovered suggests that all three burials probably occurred early in the history of the cemetery. All three burial containers appear to have been constructed solely with machine-cut nails, which argues for a date prior to 1900. Nevertheless, cut nails were used later than this date and are manufactured still. Also, a great deal of time could have passed between when the nails were manufactured and when they were used to construct any of the burial containers. Therefore, it is possible that any of the burials could date to the early twentieth century.

The other hardware recovered at Pioneer Cemetery includes utilitarian screws, white metal coffin screws, and white metal dummy screws. White metal coffin screws and dummy screws generally were out of style by the founding of the cemetery in 1888. By this time in Dallas, at least 
one of the city's undertakers ceased to purchase coffin screws in favor of the more popular thumbscrews. Also, at Freedman's Cemetery in Dallas (1869-ca. 1907), only three of the 1,049 burials that dated later than 1884 had coffin screws and only five had dummy screws. However, the five coffin screw burials and one of the burials with dummy screws at Freedman's occurred around the turn of the twentieth century (Davidson 2000:265, 268).

In more rural areas, coffin screws and dummy screws might have been used longer. For some time after their manufacture had ceased, such items could have been available to local undertakers through regional catalogs, company salesmen, or jobbers, who were wholesale dealers who purchased items in bulk (HackerNorton and Trinkley 1984). Local undertakers or merchants might also have accumulated a large back-stock of such items and offered them for sale for years after they were no longer manufactured. Two burials recovered from a cemetery in McMullen County, Texas, during the Choke Canyon Reservoir investigations contained white metal coffin screws (Fox 1984). The individual in one of the coffin screw burials was identified as a man who died in 1894 . This occurrence demonstrates that the use of much older styles of mortuary hardware did occur in remote areas. This appears to have been one of the more elaborate burials in that his coffin not only had decorative screws but also had an outside box, suggesting commercial manufacture. In contrast, 18 of the 20 burials excavated in this rural cemetery contained no hardware other than nails.

Another example of retention of anachronistic hardware is the Hacker-Norton and Trinkley (1984) study of nineteenth century hardware. The examination is based primarily on the A. L. Calhoun collection, which consists of a stock of mortuary trimmings recovered from a general store in rural South Carolina that burned in 1926. Although the proprietor rebuilt and continued to operate the store, he no longer sold the funerary hardware salvaged from the fire on a regular basis. A few white metal coffin screws, but no dummy screws, were present in the collection. Although no longer a common or popular item, these less expensive lid closures were nevertheless still available for sale well into the 1920s in some areas. Similar types of stores were probably present in many rural areas of the country, including Brazoria County, during the late 1800s and early 1900s. Therefore, with the Calhoun Collection as an analogy, a terminal date of the 1920 s for the three Pioneer Cemetery burials is suggested, but this is considered an extremely conservative estimate. The mortuary hardware from the three Pioneer Cemetery burials suggests an earlier date for these interments, most likely prior to or slightly later than 1900 .

Burials 1 and 4 appear to be roughly contemporaneous, but it is possible that Burial 3 occurred slightly later than the other two. The individual was interred in a casket instead of a coffin, and an outer box was identified during excavation. Perhaps, manufactured burial containers were becoming more affordable to the black community in Brazoria by the time of this interment. Nevertheless, the box was constructed with cut nails and was decorated with the same ornamentation as the other two burials.

Like the mortuary hardware, the personal belongings from the three Pioneer Cemetery graves are revealing. Three hairpins (Figure 5.4) were recovered from Burial 3. The hairpins were made from a material identified as either hard rubber or bakelite. The 1894-1895 Montgomery Ward and Company Fall and Winter catalog was the earliest available for consultation. Rubber hairpins similar to the ones discovered in Burial 3 are advertised for sale in this catalog (Montgomery Ward \& Co. 1894-1895:82). The time period would be consistent with when the burial occurred (post-1888). However, if constructed of

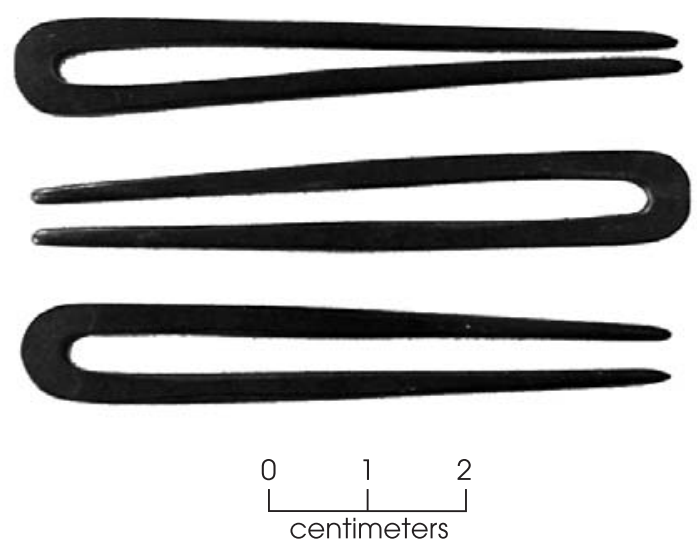

Figure 5.4. Hairpins recovered from Burial 3. 
bakelite, the burial would have to date to after the material was invented in 1907 (Panati 1989 [1987]). The pins do appear to date closer to the turn of the twentieth century, however. The latest catalog available for examination was the 1927 Sears, Roebuck and Company catalog. Although possibly available through other sellers, the catalog does not offer rubber or bakelite hairpins for sale. Instead, wire hairpins appear to have become the predominant form with a few celluloid types still available (Sears, Roebuck and Co., Inc. 1927:123). Furthermore, all hairpins advertised were crimped rather than straight, which was the type observed in Burial 3. Page 322 of the 1897 Sears, Roebuck and Company catalog offers both styles of rubber pins, although more crimped or "fancy" styles are offered than straight. This suggests waning popularity of the straight variety, probably because the crimped style held better. Prices for crimped and straight pins of similar size, however, did not differ. Unfortunately, the pages listed in the indexes for hairpins in the 1902 and 1907 catalogs were not included in the catalog reprints. It is not known if this type and style of pin continued to be offered on a large scale. The plain pins might have also been an older style but were retained by wholesalers because they were still in demand or simply because they had a large surplus of them. These items were often sold by the box at one dozen per box.

Similarly, a gold-plated hair clip or barrette with a decorative floral design (Figure 5.5), probably constructed of tin or a tin alloy, was

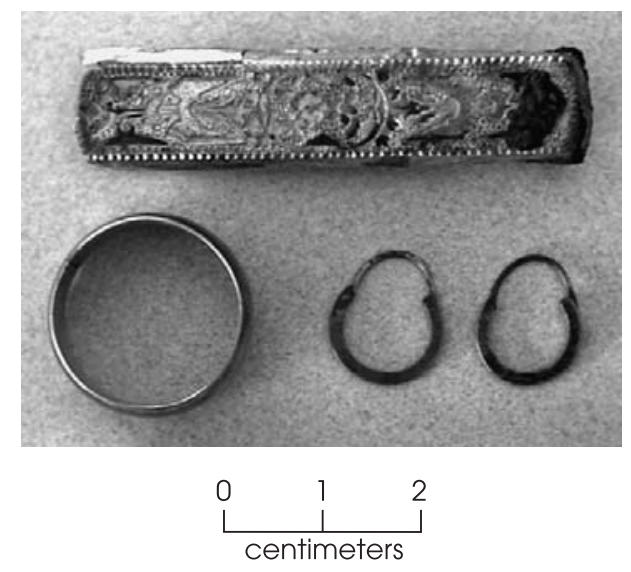

Figure 5.5. Hair clip, finger ring, and earrings recovered from Burial 3. found beneath the head of Burial 3. The pre1900 catalogs did not offer any items of this type for sale, but this does not necessarily mean that the articles did not exist or were not available from other sources. Yet, the 1902 Sears, Roebuck and Company catalog advertises five varieties of similar items called "hair lock retainers" or "hair barrettes." In particular, a heading for "New Hair Barrettes" is listed with one item described as "Something new and elegant (p 935)." Whether the novelty reference refers to hair barrettes, in general, or merely the design of that specific item is unclear.

It is possible that all three burials are roughly contemporaneous but that Burial 3 simply appears to be slightly more recent because it contained more temporally diagnostic items. The reason Burial 3 contained more diagnostic items could relate to many other factors besides temporal ones. Burial 3 was that of a woman whose age is estimated to have been $45-60$ years, whereas Burial 1 was a young woman in her late teens to early $20 \mathrm{~s}$, and Burial 4 was a child approximately 3 years of age. As a result, the differences in the material remains associated with these three burials may well reflect differences in social status or economic means.

\section{Socioeconomic Context}

Relatively few artifacts were recovered from the three burials excavated from Pioneer Cemetery. Personal artifacts from Burials 1 and 4 consisted only of buttons. One large, white porcelain button was recovered from Burial 1, whereas three white porcelain buttons of varying sizes were recovered from the torso area of Burial 4 (Figure 5.6). These also differed in design. Two were plain with four holes inside a central concavity. The third was similar, except that it had a pie-crust design along its margin. Porcelain buttons were relatively inexpensive and common during the late nineteenth and early twentieth centuries (Owens 2000). These buttons probably represent closures for burial gowns or robes for these two individuals. Such garments would have provided inexpensive and relatively easy to make burial attire, particularly if someone lacked clothing considered appropriate for a nice burial or their serviceable clothes were too valuable to bury and could be worn by another family member. The fact that each of the Burial 4 buttons is different suggests that 


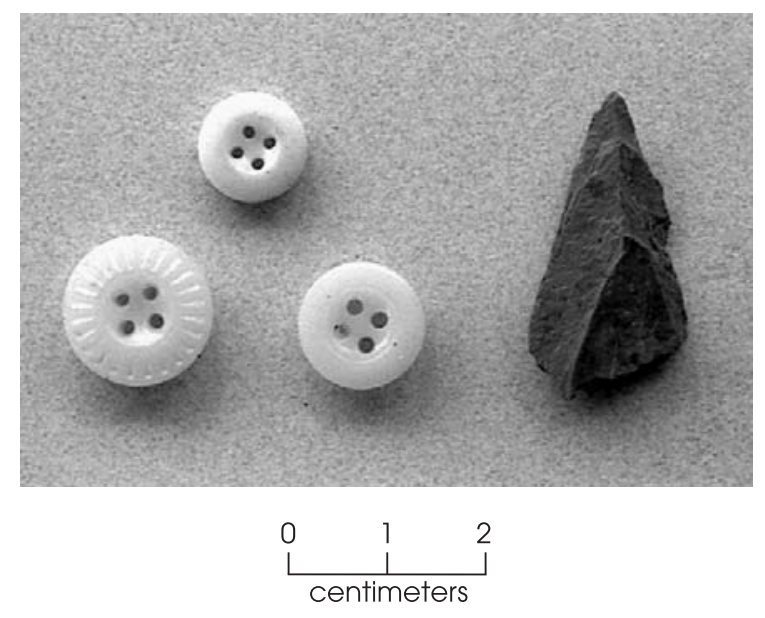

Figure 5.6. Porcelain buttons and slate fragment recovered from Burial 4.

whatever buttons happened to be handy and looked fairly similar were used to make the child's burial outfit.

Burial 3 appears to have been buried in street clothes, as indicated by the presence of 12 porcelain buttons in the torso region that were apparently arranged in two vertical rows. An additional large white porcelain button also was recovered and could indicate a closure for a skirt or undergarment (Figure 5.7). The difference in burial attire might simply represent slight temporal differences between Burial 3 and Burials 1 and 4. More likely perhaps, these differences reflect differing funerary treatment based on personal wealth or age-related status.

Burial 3 also was interred with items of personal adornment. Three hairpins made of hard rubber or bakelite were recovered. These pins might have been habitually worn by the deceased, or simply used to style her hair for viewing. Other personal artifacts include a gold-plated hair clasp, two small gold hoop-style earrings, and a gold finger ring (see Figure 5.5). The hair clasp appears to be constructed of a light-weight tin or tin alloy metal and has a stamped ornamental flower design. No identical matches could be found in any of the available merchandise catalogs, but the material suggests that the item was fairly inexpensive.

In the mid-1890s, solid gold earrings similar to those recovered from Burial 3 would have cost around a $\$ 1.00$ a pair, while gold-plated or gold-filled varieties sold for around $\$ .40$ a pair (Montgomery Ward \& Co. 1894-1895:174). Page 88 of the 1906 Sears, Roebuck and Company catalog lists a nearly identical style of solid gold earrings for $\$ .63$ a pair. Therefore, these items could have been relatively affordable to moderately expensive and probably did not represent an everyday purchase.

The gold ring was probably a wedding band. It had a plain exterior. The interior of the band was stamped with the characters " $18 \mathrm{~K}$ " and engraved in script letters with "R. P. to E. J." A vertical line down the ring suggests that it had been cut and sized to fit the individual's finger. This appears to be an item that could be obtained through retail catalogs and not require custom construction from a jeweler. An 18-karat gold band of the size recovered would have cost $\$ 3.00-\$ 5.00$ in most catalogs in the latter half of the 1890s (Montgomery Ward \& Co. 18941895:160; Sears, Roebuck and Co., Inc. 1897:417) and inscriptions were typically $2.5 \notin$ a letter (Montgomery Ward \& Co. 1895:153). Gold-filled rings could be acquired for a reduced price, but 18-karat solid gold wedding bands were recommended by most retailers and some, such as Montgomery Ward and Company, had a policy

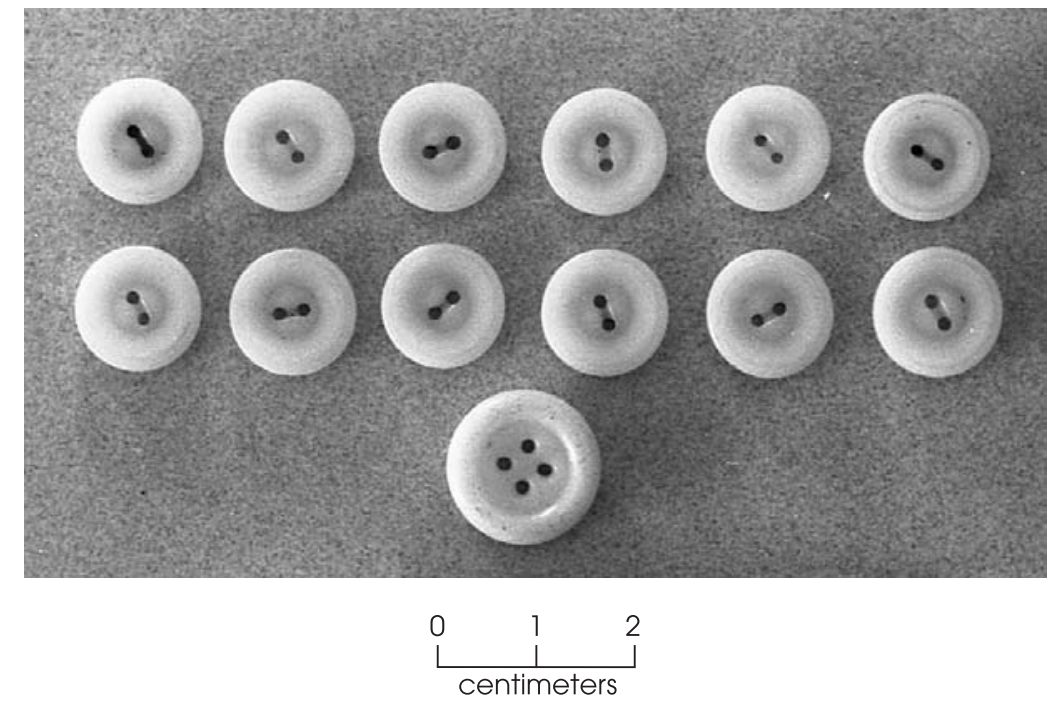

Figure 5.7. Buttons recovered from Burial 3. 
against engraving filled rings because the engraving could not be removed if the size was incorrect (Montgomery Ward \& Co. 1895:166). Because the ring with Burial 3 appears to have been solid gold, it would have been a major purchase that required lower income people to save money.

While the personal items interred with Burial 3 do not represent the most costly or elaborate pieces of jewelry available, they still represent items of some expense that would not have been purchased capriciously. As a general rule, jewelry is not commonly found in late-nineteenth and early-twentieth-century mortuary contexts. Rather, most personal artifacts from historic burials consist of clothing-related items (such as buttons). Contemporaneous African American cemeteries from Dallas (Freedman's Cemetery, Owens 2000); Houston (Third New City Cemetery, Foster and Nance eds. 2002); and southwest Arkansas (Cedar Grove Cemetery, Rose ed. 1985) indicate that few burials contained jewelry, and even these items were of limited or moderate expense. The sample from the nearby Phillips Memorial Cemetery in Galveston County contained few personal artifacts and jewelry (Dockall et al. 1996). The difference might be explained by the fact that the Phillips sample was represented primarily by items that were left behind when the burials were re-located in 1927. Even personal artifacts among a small sample of middle to upper class European Americans, from a cemetery in Dallas (Dallas Convention Center, Cooper et al. 2000) that dates to about the same time as the Pioneer Cemetery burials, were represented mostly by buttons from clothing. Although a collar stud and gold bib pin found were a little nicer than the standard utilitarian varieties, they were still relatively simple and affordable items for this group.

There are a number of reasons why the woman named E. J. (Burial 3) might have been buried with jewelry. The items may have been of strong sentimental value to the deceased or personal items that others commonly associated with that person. Her older age might also explain their presence. As mentioned previously, although the earrings and wedding ring were not extravagant objects, they probably were not accessible to everyone within the community, and such items probably took some time to accumulate. It is not unexpected that jewelry or other decorative personal items were not buried with the two younger individuals because they had not lived long enough to acquire them.

While burial containers and material belongings buried with individuals might be minimal, elaborate funerals are a common phenomenon in southern African American culture. This is in part, because during slavery, death was often seen as the only way to attain one's freedom and, therefore, a cause for celebration (Vlatch 1989). Other explanations for oftentimes lavish attention placed on the deceased include providing a certain degree of dignity to the deceased that may not have been afforded in life (Jamieson 1995), as well as folk beliefs that require that the deceased be properly memorialized and mourned to placate the spirit so it will not return and harm the family or community (Vlatch 1989). Although an elaborate casket might not have been a possibility, E. J. probably was dressed in her finery as a gesture of respect. Because of her age, she might also have been a respected elder within her family and community and, therefore, deserving of a more elaborate display at her funeral. Data from extant gravestones at Pioneer Cemetery provided by Howard (2003) indicate that most manufactured gravestones marked the graves of older individuals. This suggests that it was the elder family members who had earned the additional expense of an elaborate and permanent gravemarker.

The absence of an outer box and the atypical design of the coffin for Burial 1 suggests that the box was homemade or locally made by a carpenter with limited coffin-making skills. Use of homemade coffins was common in African American culture across the southern United States. One black informant from Brazoria reported that:

. . Sometimes they'd build a casket. Somebody would build a wooden casket. Wooden coffin. It may not have been from the family. Maybe anybody who was a carpenter or anybody who could do it. My daddy was good about making caskets. And he'd put a cover over them. He'd cover them with material on the inside. My brother and I would be playing and he would always be making a casket. (Wright 1994). 
Burial 4 also lacks an outside box and was possibly constructed locally. In contrast, Burial 3 seems to have a had a better box. An additional layer of wood at the sides, top, and bottom of the grave indicate an outer box. Also, the upper layer of wood is the same width as the box and burial pit. This suggests that the wood was from a box lid, rather than evidence of a vaulted grave. The roughness of the planks suggests a shipping crate and, hence manufacture elsewhere rather than local construction, although possibly still through a regional manufacturer. The hardware could have been purchased separately and added to the casket. For Burial 3, the manufactured casket could reflect more expense, interment at a later period in time when such a casket would be more readily available, or both.

All three burial containers at Pioneer Cemetery were constructed of the same type of wood. Wood samples from each of the burial containers in the excavated graves were sent to Phil Dering (Paloethnobotany Laboratory, Texas A\&M University) for analysis. He identified the wood from all three coffins/caskets and an outer box as hard pine, most likely loblolly or another type of southern pine (personal communication 2003). Pine, which probably would have been readily available in Brazoria, was commonly used for burial containers because it was relatively inexpensive and easy to work.

All three burials seem modest in terms of mortuary hardware, but small tacks recovered from all three burial containers suggest that the interior of each was lined with fabric. Interior lining was both common and not necessarily expensive. All three burials were ornamented with nearly identical dummy screw tacks on the lids. This similarity suggests that the hardware was obtained from the same source. However, 17 tacks were recovered from Burial 3, 5 came from Burial 4, and 2 came from Burial 1.

It is interesting that only the lid of Burial 1 was secured with white metal coffin screws $(\mathrm{n}=$ 4). The coffin lid of Burial 4 appears to have been nailed shut, while utilitarian iron screws fastened the lid of Burial 3. The use of nails for the Burial 4 lid is understandable in that less expense was typically invested in children's burials as compared to adult burials. This phenomenon was observed in other contemporaneous African American cemeteries at Cedar Grove, Freedman's Cemetery, and the Dallas
Convention Center. This pattern is perhaps explained, at least in part, by the fact that high childhood mortality rates would have limited the resources people would expend on their burials. It is notable that while the Burial 3 casket was a more expensive burial container than the other two, its lid was secured with regular flat-head iron screws. It is possible that the budget for the burial was exhausted by the purchase of the casket and tacks, and the thumbscrews might have been too costly even if they were already out of style. On the other hand, if Burial 3 is a later interment than Burial 1, the local merchant's or undertaker's stock of obsolete coffin screws might have been depleted by this time.

Overall, the burial containers at Pioneer Cemetery were modestly decorated with out-ofstyle ornaments and lacked more expensive accouterments such as handles, which suggests very limited financial resources among some of the African American population in Brazoria near the turn of the twentieth century. In contrast, most burials from Cedar Grove Cemetery (Rose ed. 1985); Freedman's Cemetery (Davidson 2000); Third New City Cemetery (TNCC) of Houston (Foster and Nance eds. 2002); and Phillips Memorial Cemetery (Dockall et al. 1996) had more contemporary trimmings with more expensive ornamentation, although this generally was reserved for burials of adults and, less often, older children. In addition, some adult burials were in plain boxes without hardware or with very minimal, old-fashioned hardware. These burials were usually much earlier, or were interments of paupers or impoverished individuals. Fraternal organizations and mutualaid societies that offered burial benefits or insurance were a common phenomenon among both whites and blacks during the nineteenth and early twentieth centuries. The existence of such groups has been noted for the communities served by Cedar Grove, Freedman's, Dallas Convention Center, and Phillips Memorial cemeteries. It is possible that the individuals from Pioneer Cemetery either did not participate in mutual-aid burial programs, or that the programs did not exist in their community at the time these people died. This may help explain the disparity in the amount and types of mortuary hardware in the Pioneer Cemetery burials as compared with the other African American samples. Nevertheless, temporal nuances between 
the various black cemetery burial samples cannot be completely discounted, but identifying precise burial chronology in archeological samples is admittedly difficult.

Though inexpensive and out of style, the mortuary hardware in the Pioneer Cemetery burials was probably the best that could be afforded by the families and friends of these individuals. It is significant that some type of ornamental hardware was present, as it indicates attention to and affection for the deceased. Indeed, cultural practices may have required that some burial ornamentation be included for the burial of all individuals and that more elaborate ornamentation be used for others. This is in stark contrast to a sample of 14 historic pauper burials excavated in Dallas, Texas (Tiné et al. 2002). This sample of contemporaneous burials (1879-ca. 1911) represents people whose funerals were funded by the county at the taxpayers' expense. Among the nine adult burials, seven were in plain wooden boxes with no ornamentation other than the occasional evidence of paint. Interestingly, all of the children's burials contained some form of ornamental hardware which suggests either an undertaker sympathetic to children or parents or other relatives who could afford the small cost of a set of thumbscrews. These pauper burials represent people who were largely forgotten and whose remains were interred in the most cost efficient manner, as opposed to people who were loved and mourned.

\section{Burial Inclusions}

All three burials contained or were in proximity to objects whose origin is not certain but could represent intentional grave inclusions or offerings. A lid from a hinged metal toolbox (Figure 5.8) was encountered in the upper shaft fill at the west end of Burial 1 during the 1999 TxDOT investigations. It was replaced when the trench was backfilled, and was rediscovered during the 2003 excavations. It is possible that this object served as a marker for the grave because a commercial headstone was not affordable or available.

Two fragments of oyster shell were present in the grave shaft fill above the outer box lid of Burial 3. Southern burials were often decorated with various kinds of objects, including shells, and shells are particularly common on African American graves (Jordan 1982:21). Many researchers believe that "the use of shells among African American graves is undoubtedly an African tradition that has survived to this day as a southern folk tradition" (Peter, Prior, Clow,
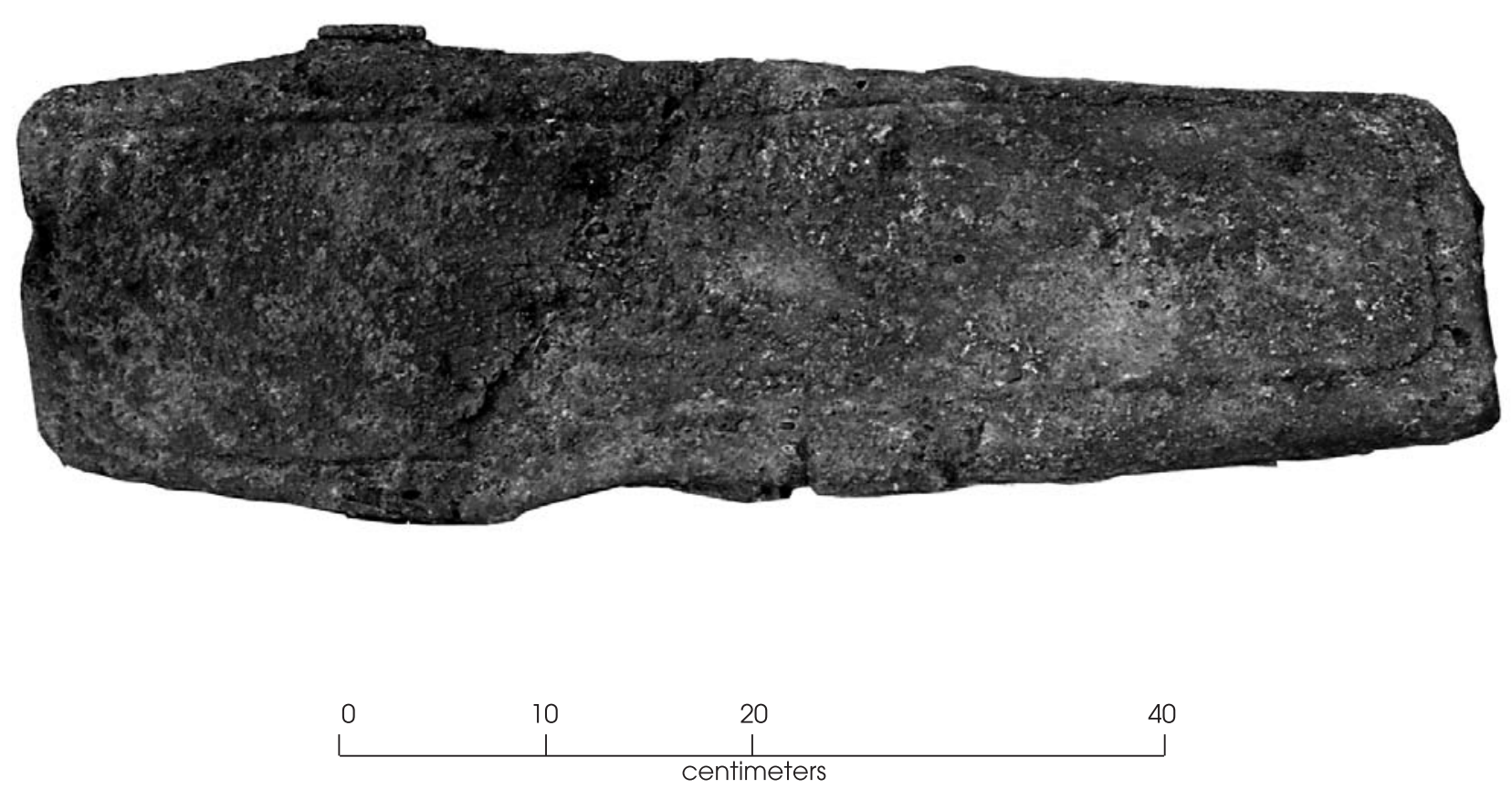

Figure 5.8. Metal toolbox lid found above Burial 1 that may have served as a gravemarker. 
and Green 2000:551-552; Vlatch 1978). There are various theories regarding what the sea shells symbolized, such as: (1) shells symbolize water and death and represent the world of the dead; (2) shells enclose the soul's immortal presence; (3) shells represent the ocean voyage from Africa; and (4) shells were symbolic of a return to Africa by sea (Afrolumens 2003; Chicora Foundation, Inc. 1996; Clow and Green 2000:457; Peter, Prior, Clow, and Green 2000:551-552). Several graves excavated at Freedman's Cemetery in Dallas were decorated with shells in addition to other objects, including those made of glass and ceramics (Clow and Green 2000). Oyster shells would have been readily available from the Gulf coast. Although possibly an accidental inclusion due to previous scraping activities, the fragments could represent a burial offering that worked its way into the burial shaft or was placed in the shaft as the grave was being filled.

A small triangular piece of slate was recovered from the coffin fill of Burial 4 (see Figure 5.6). According to TxDOT archeologist Allen Bettis (personal communication 2003), slate is not indigenous to the area and, therefore, does not represent a natural inclusion from the surrounding soil. It is not known if this is an intentional inclusion within the burial or a grave offering that worked its way from the surface into the coffin fill through bioturbation. It could represent part of a writing/drawing slate that might have been a favorite toy. The artifact is broken, which could have occurred long before its burial, or it may reflect intentional breakage. It is possible that a small piece of a writing slate board was broken off and included with the child's burial, but the rest of the slate board was kept by siblings. An alternate theory is that the slate represents an object that was ritually "killed."

African American burials were often decorated with intentionally broken objects, symbolizing the release of the spirit and breaking the chain of death (Afrolumens 2003; Jamieson 1995; Jordan 1982). Weber (2003) states that the use of "grave offerings" is a:

traditional African American practice in which various items, including pottery and personal items, are placed on top of the grave. Although the exact meaning of this custom is not clear, some have suggested that it can be traced to the African tradition of decorating the grave with items used by the deceased. The items are often "killed," or deliberately broken, to ensure that they will remain in the afterlife with their owner.

\section{SUMMARY}

Pioneer Cemetery was established in 1888, and the three exhumed burials date between 1888 and sometime after the turn of the century, perhaps as late as 1920. Attempts to define interment dates for the individual burials was hindered by the fact that few artifacts were recovered. The mortuary hardware associated with these burials was more a testament to the relative social status and financial condition of the individual's families than an aid in determining interment dates. Nevertheless, the circumstantial evidence suggests that at least two of the three burials (Burials 1 and 4) probably took place prior to 1900 . Some of the associated personal items, as well as evidence of a commercially manufactured casket, suggest that Burial 3 is probably later than the other two burials and might have occurred after 1900 .

The material remains reveal many cultural and social aspects of African American society in southern Texas at the turn of the century. In relation to other archeological samples from contemporary burial grounds, the mortuary hardware seen at Pioneer Cemetery was less elaborate and relatively inexpensive. Factors such as slight differences in interment dates, the rural location and small population, and lack of mutual aid societies to provide burial services, are all possible reasons for these differences. Like mortuary hardware, personal artifacts were generally limited in number and type, and they too reflect limited financial expenditures. Burials 1 and 4, which represent a young woman and a very young child, were recovered with only a few porcelain buttons that probably served as closures for burial gowns or robes. These garments would have been inexpensive and easy to make and would also have permitted the clothing of the deceased to be used by someone else. In contrast, greater status and wealth seem to be reflected in the more elaborate casket and personal belongings associated with the older woman in Burial 3. This burial differed in that the woman was buried in street 
clothes and was adorned with earrings, hair pins, and what appears to be a gold wedding ring. Although none of the items were extremely expensive, the wedding ring was a significant purchase. Such items were probably not readily available or affordable for many members of the community at the time, and these personal items were probably accumulated over time. Because she was between 40 and 65 years old at her death, she had greater opportunities to acquire these possessions, and they were likely of great sentimental value as well. As an older member of her family and her community, she apparently deserved and received a more elaborate burial than many of her younger contemporaries would.

In terms of personal artifacts, the Pioneer Cemetery burials do not differ greatly from other burials of the same time period. Typically, even financially advantaged people did not bury expensive items with the deceased. As was seen at Pioneer, turn-of-the-century African Americans were occasionally buried in other cemeteries along with their jewelry and other types of personal adornment. Whether for sentimental reasons or out of respect for the deceased, there seems to be a correlation between a person's age and the quality and quantity of personal material possessions buried with them. Quite simply, it was the older people who would have gained the respect of their families and community and earned the privilege of being buried with their belongings and having more elaborate funerary trappings.

The material culture directly associated with the three burials exhumed from Pioneer Cemetery, in addition to the possible grave offerings and a homemade gravemarker, indicate that these individuals and their supporting community were of modest economic means. Such conditions are expected within a society of free blacks only a few decades removed from slavery. Nevertheless, the evidence shows that these people probably were given the best burials that were financially available to them, and their burials reflect traditional Christian beliefs, perhaps blended with some residual traits derived from Africa. 


\section{BIOARCHEOLOGICAL ANALYSIS}

The following chapter discusses the osteological remains recovered during the Pioneer Cemetery burial relocation project. The skeletal and dental remains of three individuals were excavated and analyzed during this project. Skeletal preservation differed among each burial and ranged from extremely poor (little more than teeth and a few bone fragments recovered) to good (nearly all elements represented and complete, though not always intact). As a consequence of the size and quality of the available data, interpretations are limited. However, with few exceptions (i.e., Freedman's Cemetery in Dallas) most historical skeletal samples from Texas are small or poorly preserved, and most represent less politically and economically powerful groups. Each of these burial samples, particularly when viewed in relation to others, has contributed to the current understanding of the quality of life and social dynamics of the various classes of people in Texas from the mid1800 s to early $1900 \mathrm{~s}$. As such, any further additions to the current knowledge base-no matter how small the sample-are important for refining osteological interpretations and historical perceptions of our state.

\section{REFERENCE SKELETAL SAMPLES}

Because such a small number of individuals were excavated from Pioneer Cemetery, direct comparison with other burial samples is not possible. However, an understanding of the bioarcheology of contemporaneous cemeteries of similar region, ethnic composition, or economic circumstances helps put the limited data acquired from Pioneer Cemetery into better perspective. Six different burial samples are refer- enced throughout the text when applicable, and conclusions about their archeology and biology are discussed in relation to findings from the Pioneer Cemetery sample. These groups are as follows:

Cedar Grove Cemetery (1890-1927). Eighty individuals were excavated from this church cemetery in rural southwest Arkansas. Individuals interred in this cemetery are believed to have been emancipated plantation slaves-turnedsharecroppers and their descendants. Examination of these skeletal remains indicates that the population was under considerable biological stress (Rose ed. 1985). Only approximately 40 percent of this cemetery was excavated, and the time span for these particular interments has been refined to 1900-1915 (James Davidson, personal communication 1998).

Third New City Cemetery (1850s/1880-1910). The remains of 355 individuals were recovered from a portion of a predominantly black city cemetery in Houston, Texas. Although the city cemetery officially opened in 1880, patients from a hospital that formerly stood on the property may have been buried there as early as the 1850 s. Skeletal data suggest that, although health disorders were present, the burial population was generally healthy (Foster and Nance eds. 2002).

Phillips Memorial Cemetery (1880s-1927). Fifty-three interments were excavated from an African American cemetery in rural Galveston County, Texas. These burials represent the remnants of human interments that were partially exhumed and relocated in 1927. Partial to complete skeletal remains of 43 individuals were 
recovered and examined (Dockall et al. 1996). Though not an ideal sample, the similar setting, time period, location, and ethnic composition provide an interesting analog for Pioneer Cemetery.

Freedman's Cemetery (1869-ca. 1907). This African American cemetery in Dallas, Texas, was the city's only burial ground available to the black community for over 30 years, and represented African Americans of all socioeconomic classes (Peter, Prior, Green, and Claw 2000). It is a very large sample of 1,157 burials, and cannot be directly compared with the small sample from Pioneer Cemetery. The Freedman's sample, however, presents relevant information about the health and well-being of blacks in Texas during the post-Reconstruction era near the turn of the twentieth century (Condon et al. 1998; Tiné 2000).

Dallas Convention Center (1840-1921). This cemetery is also commonly known as Pioneer Cemetery, but will be referred to in this report as the Dallas Convention Center (DCC) sample, after its location in downtown Dallas, Texas. The cemetery consists of burial grounds for two fraternal organizations-the Masons and the Odd Fellows. Fifteen burials were removed from the Odd Fellows portion, and individual interment dates range from the 1880 s to roughly after 1910 (Cooper et al. 2000). Individuals interred at the DCC were middle to upper class whites and represented members of both the social elite and the mainstream of Dallas during the nineteenth and early twentieth centuries. Associated burial artifacts from the excavated graves suggest that, while well-off, these particular individuals were probably members of the middle class.

Potter's Field (1878-ca. 1911). This sample of 14 European American paupers in Dallas, Texas, offers an example of a different (i.e., non-African American) disenfranchised social class. Although no direct evidence of nutritional deficiency was present, high frequencies of childhood metabolic stress, infection, and dental pathology were observed (Tiné et al. 2002).

\section{DEMOGRAPHY}

For meaningful information to be drawn from a population, it is necessary to understand its composition. This is important both to ensure that appropriate comparisons are made and that processes that affected each population and its life quality are comprehended. For comparative purposes, populations are classified according to various demographic categories (i.e., socioeconomic classes) that reflect social structure of the society at large. Where an individual fits into the social structure affected how they were regarded and treated by others, what types of benefits were available to them, and the risks to which they were vulnerable. In addition, when the osteological data are examined by demographic categories, the patterns that emerge reflect the stresses that the physical and social environment presented for each particular population and how successfully that population adapted to them (i.e., adaptive efficiency). Because they can be identified osteologically with a certain degree of precision, ethnic affinity, sex, and age are discussed in this section.

\section{Biological Affinity and Ethnicity}

For years, the concept of race has been a controversial topic in the field of physical anthropology both because of past misapplications of morphological variation in humans and the inability to clearly define race. In addition, social and biological definitions can conflict, and genetic admixture can blur observations of biological ancestry. Certain morphological characteristics, however, are predictably common among broad groups of people who are considered ethnically distinctive, and these can be helpful in human identification (Gill and Rhine 1990). In historic cemetery studies, skeletal traits are discussed in terms of biological affinity, which simply refers to how closely related an individual is to a broader population group. Biological affinity is then used to infer the ethnicity of the individual and the population. The term "ethnic" is generally defined as "of or relating to sizable groups of people with a common, distinctive racial, national, religious, or cultural heritage" (The American Heritage College Dictionary, Third Edition, 1997). Using this broad definition, the ethnic groups that are widely recognized by people in the United States and around the world-such as African, Asian, and European-are applicable to this study. 
Chapter 6: Bioarcheological Analysis

Historically, the use of Pioneer Cemetery was reserved for individuals of African ancestry who were recognized ethnically and socially as being black or African American. The two adults in the Pioneer Cemetery burial sample had sufficient bone preservation for observations on ethnicity to be made, and the observed features are consistent with individuals of African ancestry. The skull, particularly the facial region, is the most diagnostic part of the skeleton for assessing ethnic origin. No crania were sufficiently intact to permit the precise measurements used in discriminate function equations to assess ethnic origins. Furthermore, the limited amount of time for analysis precluded any attempts to reconstruct crania. Likewise, deterioration of the fragile facial bones limited the number of morphological observations that could be made, and results were not always clearly defined. Maxillae from Burial 1, as well as fragments from Burial 3, suggested guttering of the basal nasal region. Alveolar prognathism also was indicated by the maxillae and mandible of Burial 1. These features often occur in people of African origin (Bass 1995; Rhine 1990; Stewart 1979; Ubelaker 1989). The facial bones of Burial 3 were not sufficiently preserved for these observations. In addition, both individuals from Burials 1 and 3 exhibited dense cranial bones, a feature more common among African populations (Bass 1995:92). Finally, venous grooves were present on the frontal of Burial 3. This trait is more frequent among, although not necessarily indicative of, individuals of African ancestry (Rhine 1990).

Though not as effective an indicator, features of the femur can suggest ethnic affinity. None of the three Pioneer Cemetery burials had a femur sufficiently intact enough to measure intercondylar notch height, which can help distinguish whether an individual is more likely of European rather than African descent (Baker et al. 1990). Nevertheless, the femoral shafts of Burial 1 were sufficiently complete to permit observation of the anterior-posterior curvature of the femoral shaft. Europeans and Asians typically demonstrate bowing, while the femoral shafts of individuals of African descent are generally straight (Stewart 1979:232; Ubelaker 1989:119). No noticeable anterior-posterior curvature was noted.

\section{Age and Sex}

Due to the small sample size of the burials excavated, inferences about the age and sex composition of Pioneer Cemetery from the skeletal data are extremely limited. Three individuals were exhumed during the current investigations. These consisted of two adult females-a young woman between 17 and 23 years old and an older woman between 45 and 60 years old-and a child of undetermined sex. The child is estimated to have been $2-4$ years old at the time of death. The absence of other demographic groups (e.g., males) from the sample is due to the small sample size, and these individuals do not reflect the cemetery population as a whole. On the other hand, the groups represented are informative about the larger population.

To illustrate, mortality profiles based on individuals of known ages at death or specific age ranges from two large historic cemetery samples are presented in Figure 6.1. Age assessments based on skeletal analyses were made for 1,110 individuals in the Freedman's Cemetery and 79 individuals in the Cedar Grove Cemetery (Condon et al. 1998; Rose ed. 1985). These data are not intended for direct comparison with the burials from Pioneer Cemetery. Rather, they are offered as examples of mortality patterns of sizable contemporary samples to demonstrate how the Pioneer Cemetery burials might be distributed within their cemetery population.

The two postemancipation African American samples indicate similar patterns. Both demonstrate extremely high mortality among infants and young children. Deaths decrease dramatically around age five and begin to increase again in adolescence, a time when one begins to assume the duties of adulthood and their inherent risks. This is also a period when the immune system is usually at its peak and death can actually result from exaggerated inflammatory responses to certain pathogens (Burnet and White 1972). Conversely, if multiple or severe episodes of biological stress are incurred during childhood, one's resistance might be compromised and result in early mortality when faced with biological insult. Deaths increase steadily throughout adulthood and peak in the fourth decade before declining steadily, presumably because few people are surviving into old 


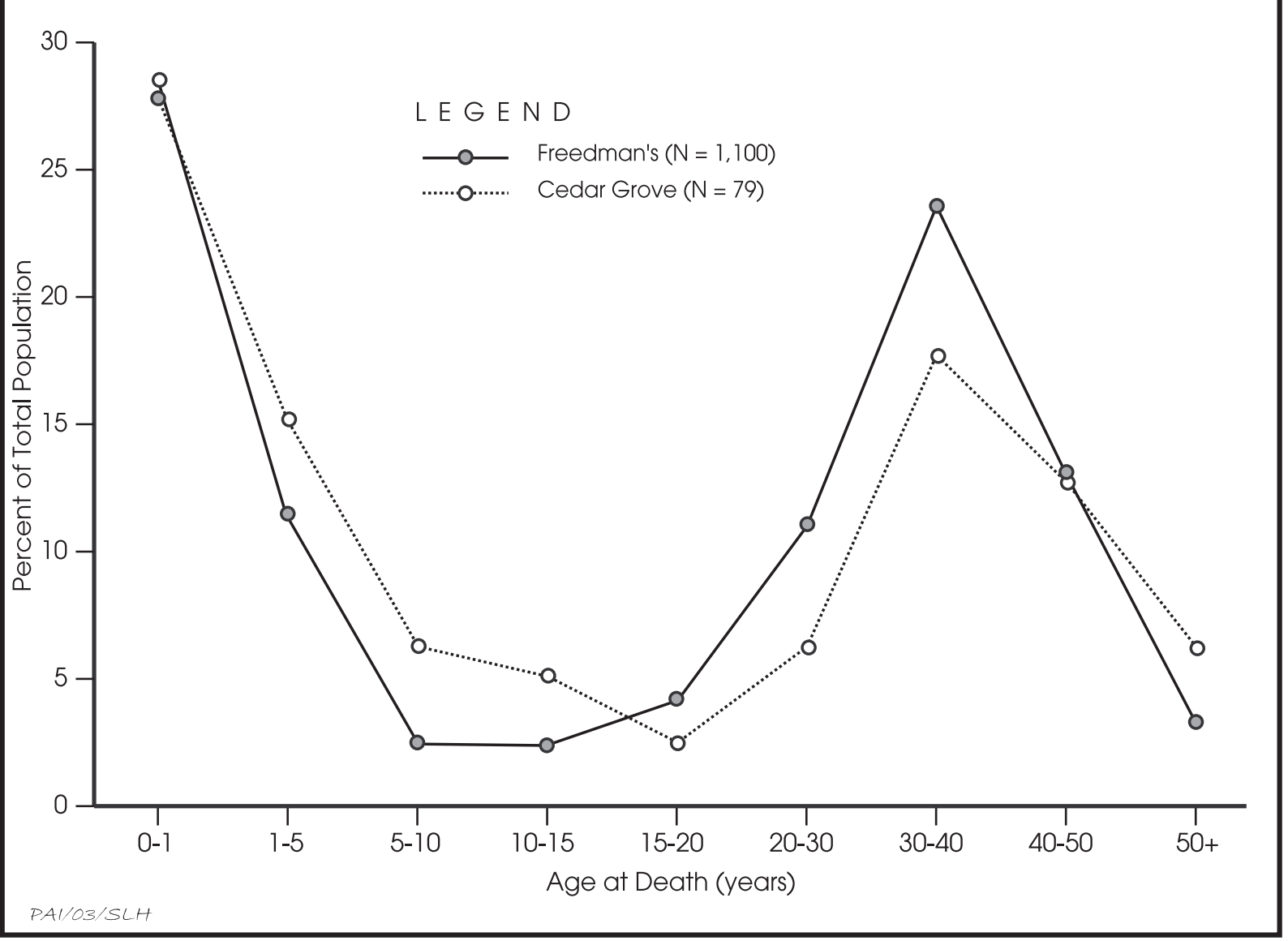

Figure 6.1. Comparison of age at death for two large historic cemetery samples. Data are from Condon et al. (1998) and Rose (1985).

age, although Tiné (2000) did postulate migration factors which could partially account for the underrepresentation of older adults at Freedman's Cemetery. In essence, younger adults were probably more likely than older individuals to have moved to Dallas in search of work following emancipation, and the cemetery would have stopped receiving burials by the time many reached their fifties. Nevertheless, compromised longevity resulting from stresses related to the adjustment of self-sufficiency in a, no doubt, hostile environment cannot be completely dismissed because many younger adults died. The Cedar Grove sample does not demonstrate as dramatic a shift in adult mortality, but it does indicate that few people survived beyond 50 years of age. Skeletal evidence of elevated biological stress among this group may be a contributing factor to reduced longevity.

The Pioneer Cemetery burials are repre- sented by three age groups-very young, young adult, and middle-aged to elderly adult. The two younger age groups conform to the general atrisk ages for elevated mortality. The older adult could be a chance discovery or the cemetery might contain a higher proportion of older individuals because those who were middle-aged or older at the time of emancipation might have been more reluctant or less able to leave Brazoria.

Inscription information collected from the existing gravestones at Pioneer Cemetery was provided by Nancy Howard (2003) of the Cemetery Committee of the Brazoria County Historical Museum. The demographic data were examined in an effort to discern any patterns within the larger cemetery population. Although the cemetery was founded in 1888 (Dismukes and Bettis 2002), the earliest death date derived from a marked grave is 1899 (Howard 2003). 
Burials still occur in the cemetery, and the most recent one dates to 2000 . Of the 59 gravestones recorded, information was examined for the earliest 46 . The elimination of the later burials (13 burials dating from 1976 to 2000) is based on the presence of a large temporal gap in dates between 1948 and 1976. Furthermore, the burials from 1948 and earlier are older than 50 years of age. The Texas Historic Commission defines a historic cemetery or burial as one that is at least 50 years old, and it is the historic component of the cemetery that is of interest for this study.

Although the gravestone data give insight into the culture of the Pioneer Cemetery population, only limited information can be gleaned about the constituents of this population because most of the graves are not marked. This is probably the result of several factors. Some permanent grave markers probably deteriorated through time, and others may have been stolen, vandalized, or destroyed by land-clearing activities in the mid-1980s (Dismukes and Bettis 2002:3). It also is likely that many graves were not marked with headstones to begin with or were marked with more ephemeral markers. This may be due in part to people's limited financial resources, and the presence of several homemade, hand-carved gravestones in the cemetery suggests that manufactured stones may have been too expensive for some families. Some of the grave markers exhibit symbols of fraternal organizations, and these groups may have offered burial insurance or other benefits to their members (Bryant 1989; Prior and Schulte 2000) that may have furnished gravestones or at least made it possible for their families to afford to purchase a stone monument.

The temporal distribution of gravestones at Pioneer Cemetery shows a strong correlation between a person's age at death and the occurrence of a headstone. Within the sample of marked graves with age-at-death information, most individuals with a grave marker are 50 years of age or older (Figure 6.2). Of the 46 grave markers with death dates between 1899 and 1946, 24 (52 percent) of the headstones are for people 50 years old or older. When all of the people 30 years old or older are combined, their headstones $(\mathrm{n}=35)$ account for 76 percent of the total. It is likely that only the older individuals were able to attain a certain status or level of veneration that would justify the expense of a manufactured monument rather than other types of markers, such as unmarked native stones or perishable wooden markers. Furthermore, only the oldest individuals would have had adult children who could help with the cost of a manufactured stone marker, whereas younger adults would probably have left dependents behind. For young adults with children, purchase of a gravestone would have been a financial burden on their family and friends.

Perhaps the most meaningful information that can be gleaned from the Pioneer Cemetery headstones is that many adults did live into old age. The oldest recorded adult was 91 years old at the time of death, and the average adult died at 54.6 years of age. Therefore, while it is uncertain how many individuals survived past 50 within the entire cemetery population, it is significant that many did. Furthermore, 9 of the 39 adults with known ages were born prior to 1865 and, hence, probably spent part of their lives as slaves. Yet, they lived to fairly advanced ages. People who were born before 1865 ranged in age from 57 to 91 years at the time of death.

Infant and child gravestones are conspicuously missing (see Figure 6.2). Only two children (ages 8 and 12) in Pioneer Cemetery have gravestones, and one of these is listed with several others on what appears to be a family grave marker. Monuments for infants and children were often smaller than their adult counterparts and, thus, more vulnerable to loss or destruction. Nevertheless, economics is a more probable explanation. In an era when young child mortality was particularly high, and when considering a group that probably had few economic resources or opportunities, both the financial and emotional investment in an elaborate grave for each child could have been overwhelming. It is likely that many children had only ephemeral markers or, in some cases, no grave marker at all.

When sex distribution was examined, 23 gravestones indicated female or probable female burials, 17 suggested male or probable male burials, and sex could not be determined for the remaining 6 . While females slightly outnumber males, the disparity might be cancelled out by the individuals of undetermined sex, but the proportions of males and females at Pioneer Cemetery is not unreasonable. In the sample of 555 burials from Freedman's Cemetery, roughly 50 percent $(\mathrm{n}=274)$ are female (Tiné 2000:Table III-97). At Freedman's Cemetery, 
males outnumber females in the pre- 1900 sample ( 55 to 45 ), but females slightly outnumber males in the post-1900 sample (229 to 226 ).

Finally, death dates for 46 marked burials at Pioneer Cemetery were examined to determine if any temporal trends were present. When divided into 5-year increments, only 1 to 3 burials occurred in each period until the latter half of the 1930s when the number of burials increased dramatically to 19 (Figure 6.3). Nine of the marked graves represent people who died in 1939 alone. Most of the recorded deaths $(n=8)$ between 1935 and 1939 were of people over 50 years of age. This might be expected, as individuals who were children and young adults at the time of the cemetery's founding were growing old by this time. However, the deaths that occurred in 1939 consist of a 12-year-old child, two individuals in their twenties, two in their thirties, and three over 50 years old. This distribution may be an accurate representation of the age groups that actually died in 1939. If so, it suggests that some type of catastrophic event or epidemic occurred in 1939, but none of the limited historical data summarized by Dismukes and Bettis (2002) and Kleiner (2002) mention any event that might explain the unusual number of deaths within that year. No significant floods or hurricanes are mentioned on the Texas Coast for 1939 by Bomar (1983).

The number of marked burials decreases by one-half between 1940 and 1944 and continues to decrease until the late 1940 s but remain higher than the pre-1935 average. This decrease probably reflects the declining use of Pioneer Cemetery as it became full and other burial grounds became available for African Americans in Brazoria.

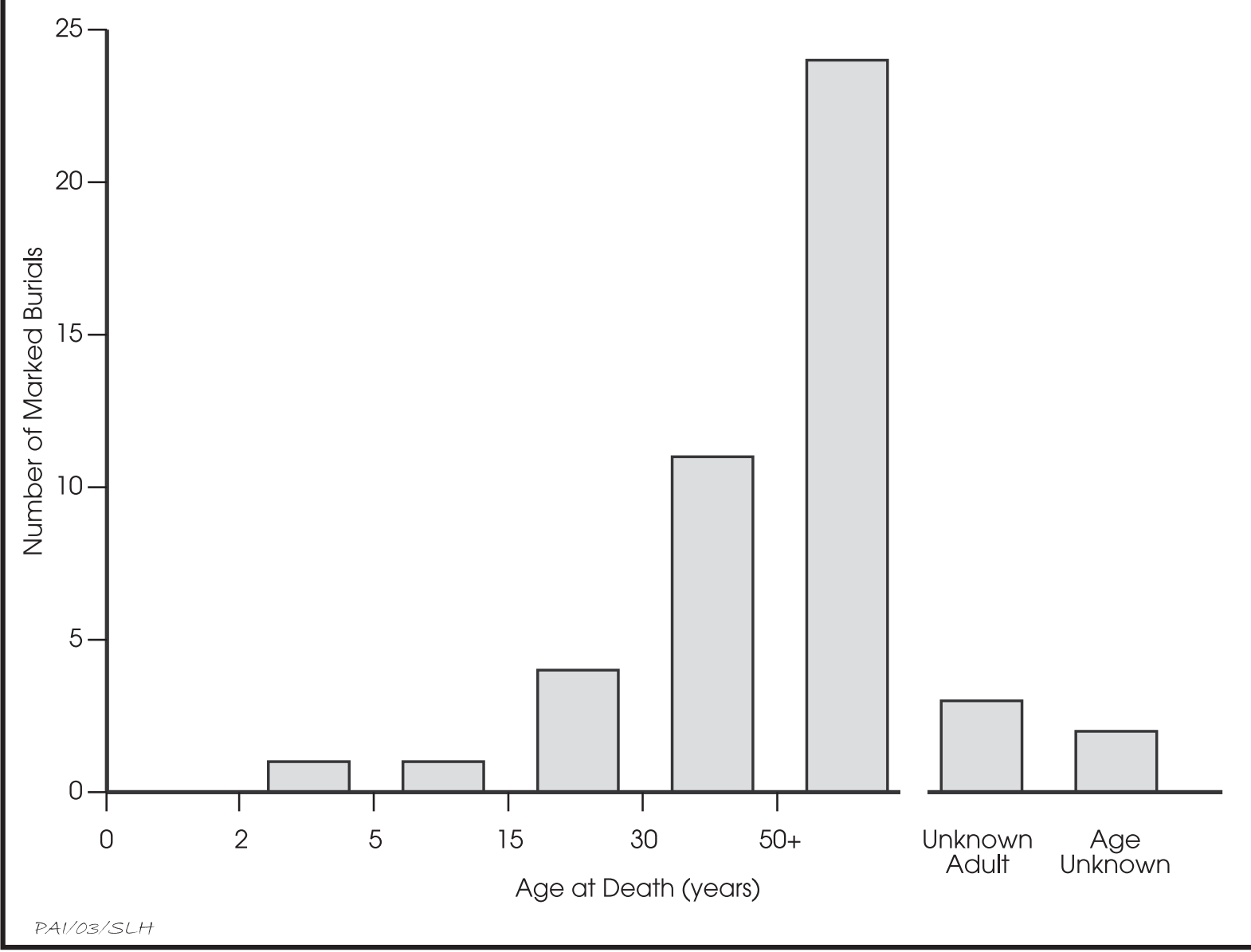

Figure 6.2. Numbers of marked burials $(n=46)$ in Pioneer Cemetery by age category. Data are calculated from the cemetery headstone list compiled by Howard (2003). 


\section{PALEOPATHOLOGY}

The type and frequency of biological or environmental stressors (agents or conditions that cause stress to an organism) to which members of a population are susceptible may reflect the conditions of the physical and social environments that encompass the group. Many stressors may manifest themselves as visible or measurable attributes on bones, and these skeletal anomalies sometimes remain observable after death. How well various bone anomalies reflect biological stressors that impact adaptation and survival is a matter of debate. Wood et al. (1992) warn against the assumption that the presence of skeletal lesions or enamel hypoplasias are indicators of poor adaptation. Rather, they assert that individuals with these defects can represent survival of a given stressor, whereas those lacking the defects may have died before the stressor had a chance to impact the hard tissues. These concerns are well noted. The presence of such defects, however, indicates that an individual has been biologically compromised and is thus in a weaker state when confronted with additional stress. When factors such as age at death and whether a lesion is in an active or healing state are considered, the presence of stress indicators can suggest how successfully a population has adapted to its environment.

\section{Enamel Defects}

Enamel hypoplasias are areas (usually in the form of pits or horizontal furrows) of reduced enamel thickness. Although sometimes of genetic origin or the result of localized trauma, they are usually the consequence of the temporary redistribution of available nutrients away from the growth process and toward the maintenance of more vital biological functions during times of illness or insufficient nutrition (Goodman and Rose 1991). Both adults from Pioneer Cemetery exhibited enamel hypoplasias. Burial 3 had a hypoplastic line on her right maxillary first premolar. The left was not recovered. Location of

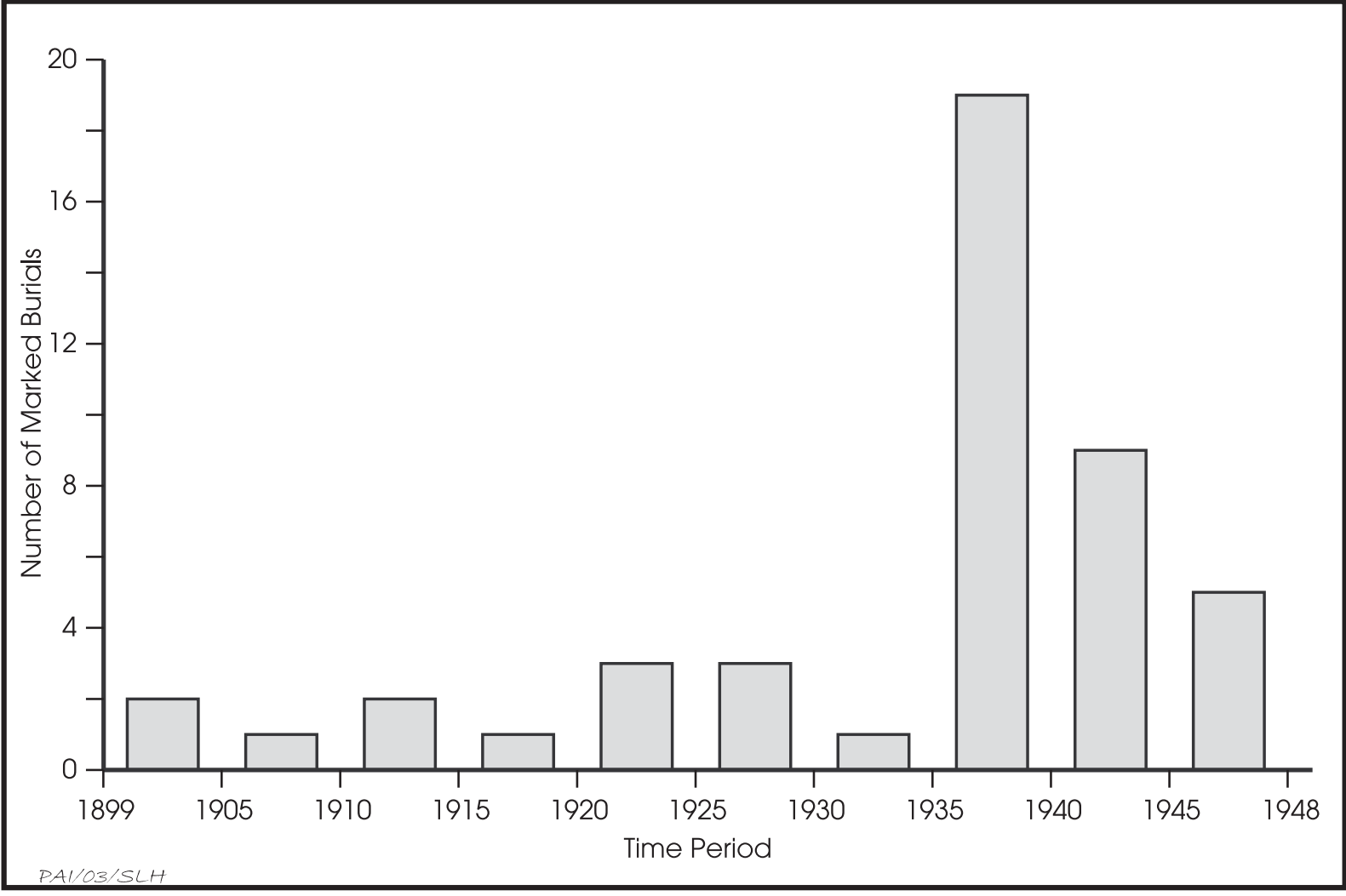

Figure 6.3. Temporal distribution of marked burials in Pioneer Cemetery. Burials are grouped into 5-year intervals. Data are calculated from the cemetery headstone list compiled by Howard (2003). 
the hypoplasia, based on measurement from the cemento-enamel junction of the tooth to the most occlusal aspect of the defect was compared with a chart devised by Goodman et al. (1980) for permanent dentition development formation to provide a general idea of when the defect was formed. The individual was approximately 4.5 years old when the stress resulting in the hypoplasia occurred. Maxillary central incisors and mandibular canines are thought to be the teeth most sensitive to childhood metabolic stress, however (Goodman et al. 1980:526). No enamel defects were observed on the maxillary central incisors of Burial 3, although they are somewhat worn. The mandibular canines were not recovered. Therefore, it is not known if she encountered any additional significant stress episodes during childhood.

Burial 1 had a nearly complete dentition. Multiple hypoplastic episodes were observedthree lines on the maxillary central incisors and one each on the mandibular incisors. Using the measurement chart devised by Goodman et al. (1980) described above, these observations translate into roughly three stress episodes. The earliest occurred approximately between the ages of 1.5 and 2.0 years of age, while the later episodes happened around age 2.5 and 3.5. Factors accounting for the hypoplasias can include weaning stress, seasonal food shortages, or illness. Were she a young child during the earlier years of emancipation when African Americans were adapting to self-sufficiency in an environment that was not supportive of their newfound freedom, these stresses might have been exacerbated. As with the other two burials, the cause of her death is unknown. However, these early stresses might have compromised her immunity and left her more vulnerable to the plethora of illnesses that killed many people before the advent of antibiotics.

No enamel defects were evident on the deciduous dentition or developing permanent teeth of Burial 4. Nevertheless, the child demonstrated the most extreme expression of childhood stress-death.

Frequencies of enamel hypoplasias from five historic burial samples roughly contemporaneous with Pioneer Cemetery are listed in Table 6.1. Although direct comparisons cannot be made due to discrepancies in sample sizes, high frequencies of enamel hypoplasias are not uncommon among most of these cemetery samples, particularly among the disadvantaged groups. In this instance, all groups listed in Table 6.1, except DCC, fall into this category. Burial goods recovered from the graves excavated from Pioneer Cemetery suggest that they represent earlier interments in the cemetery, probably no later than the mid-1920s and likely earlier. Although it is possible that Burial 3 could have even been a child during the latter years of slavery, the three individuals excavated represent people who were probably children during the Reconstruction and post-Reconstruction eras. These were times of transition and social upheaval, and blacks were targets of not only physical but economic and political aggression by whites attempting to maintain supremacy. Therefore, evidence of moderate to severe childhood stress among the Pioneer Cemetery burials is expected.

\section{Porotic Hyperostosis and Cribra Orbitalia}

Porotic hyperostosis and cribra orbitalia are frequently associated with iron-deficiency anemia (Huss-Ashmore et al. 1982). Factors that

Table 6.1. Frequencies of enamel hypoplasia among various historic cemetery samples

\begin{tabular}{lccl}
\hline Site & $\begin{array}{c}\text { No. of } \\
\text { Observable } \\
\text { Individuals* }\end{array}$ & $\begin{array}{c}\text { Percent } \\
\text { Occurrence }\end{array}$ & Source \\
\hline Cedar Grove & 36 & 83.3 & University of Arkansas raw data (n.d.) \\
Freedman's Cemetery & 200 & 68.5 & Tiné (2000) \\
Third New City Cemetery & 277 & 50.0 & Foster and Nance eds. (2002) \\
Dallas Convention Center & 10 & 40.0 & Cooper et al. (2000) \\
Potter's Field & 8 & 75.0 & Tiné et al. (2002)
\end{tabular}

* Refers to the number of individual burials for which evidence of enamel hypoplasia was observable out of the total burial population. 
contribute to iron-deficiency anemia can include blood loss, chronic diarrhea, inadequate absorption of the mineral, increased demands for iron, and insufficient amounts of bioavailable iron in the diet (Stuart-Macadam 1989). Symptoms include fatigue, weakness, headaches, and various gastrointestinal disorders (Fairbanks and Beutler 1972; Stuart-Macadam 1989). Furthermore, the individual is weakened immunologically (Baynes and Bothwell 1990; Goodman 1994) and, therefore, is vulnerable to other debilitating conditions. In addition to reduced endurance and compromised immunity, clinical studies have indicated that cognitive abilities can be adversely affected (Baynes and Bothwell 1990; Goodman 1994; Liebel et al. 1982). Baynes and Bothwell (1990:142) have noted that impaired neurological functioning resulting from iron deficiency anemia in children is not entirely reversible. As a result, the condition of anemia is conceivably detrimental on both the levels of the individual and larger social units.

No cribra orbitalia or porotic hyperostosis was observed on the two adult crania from Pioneer Cemetery, although it is possible that any lesions incurred by the older individual could have long since healed by the time of her death. With only two individuals to examine, it is not possible to assume that the remainder of the cemetery population did not suffer from anemia. In particular, some individuals in the population might be genetically predisposed to a specific type of anemia. Sickling of the red blood cells is a hemoglobin variation often found among African populations. In its homozygous form, sickle-cell anemia arises because the red blood cells are elongated and cannot easily pass through the capillaries. This condition is debilitating and can be life threatening (Aufderheide and Rodríguez-Martín 1998:348). In its heterozygous form, however, only a portion of the cells are sickle-shaped, which confers some immunity to several forms of malaria (Gibbs et al. 1980; Kiple and King 1981; Savitt 1988), although a milder form of anemia can result. As a consequence, skeletal manifestations similar to iron-deficiency anemia may arise, and the two are not always easily distinguishable from one another (Aufderheide and RodríguezMartín 1998:348). Nevertheless, the environmental setting in a rural area near the Brazos River suggests that procurement of adequate iron would not be a problem if allowed to exploit the natural environment. Game could have been hunted, and fish would have been a readily available source of iron and animal protein. In addition, this protein could augment absorption of iron from foods in which iron is less biologically available (Baynes and Bothwell 1990:138).

Despite a rural environment and plentiful natural resources, a sample of burials from Cedar Grove Cemetery in southwest Arkansas indicates extreme biological stress (Table 6.2), including high frequencies of porotic hyperostosis and cribra orbitalia. In a few instances, these expressions are probably the result of an etiology besides iron deficiency (e.g., sickle cell anemia or another type of nutritional deficiency, such as rickets). In most, it probably reflects iron deficiency due to various conditions such as inadequate diet, parasitic infection, blood loss, diarrhea, or chronic biological strain. Rose (1985:149) offers economic limitations imposed by the sharecropping system in which most of the Cedar Grove population participated, poor economic conditions in the region, and introduction of the Jim Crow era as factors that would have been detrimental to the diet and health of local blacks. Detailed historical data regarding the life of blacks in Brazoria after emancipation are currently unavailable. It is known that prior to this time, Brazoria County was a major slaveholding county, and that it had a plantation economy. It is also known that, as in much of the South, a backlash by whites against the changes brought about during Reconstruction negated any improvements that might have come about (Kleiner 2002). Therefore, it is possible that African Americans who did not leave Brazoria were eventually absorbed into a sharecropping system and incurred similar hardships. However, this scenario remains to be substantiated, and the limited skeletal data do not support it.

Overall, severe anemia does not appear to have been a major problem in Texas during this time period (see Table 6.2). Only one individual from the observable affluent DCC sample indicated a possible instance of porotic hyperostosis, and no evidence of porotic hyperostosis or cribra orbitalia was present among the white paupers from Potter's Field. Among the African American samples, porotic hyperostosis or cribra orbitalia was occasionally present but usually in low frequencies. The larger samples may explain the greater occurrence of these disorders in the African American Texas samples, 
Table 6.2. Frequencies of porotic hyperostosis and cribra orbitalia among various historic cemetery samples

\begin{tabular}{|c|c|c|c|c|c|}
\hline \multirow[b]{2}{*}{ Site } & \multicolumn{2}{|c|}{ Porotic Hyperostosis } & \multicolumn{2}{|c|}{ Cribra Orbitalia } & \multirow[b]{2}{*}{ Source } \\
\hline & $\begin{array}{c}\text { No. of } \\
\text { Observable } \\
\text { Individuals* }\end{array}$ & $\begin{array}{c}\text { Percent } \\
\text { Occurrence }\end{array}$ & $\begin{array}{c}\text { No. of } \\
\text { Observable } \\
\text { Individuals* }\end{array}$ & $\begin{array}{l}\text { Percent } \\
\text { Occurrence }\end{array}$ & \\
\hline Cedar Grove & 76 & 21.1 & 76 & 26.3 & Rose ed. (1985) \\
\hline Freedman's Cemetery & 652 & 5.7 & 435 & 7.6 & Tiné (2000) \\
\hline Third New City Cemetery & 136 & 4.0 & 136 & 3.0 & $\begin{array}{l}\text { Foster and Nance, } \\
\text { eds. (2002) }\end{array}$ \\
\hline Phillips Memorial Cemetery & $43 * *$ & 9.3 & $43 * *$ & 0.0 & Dockall et al. (1996) \\
\hline Dallas Convention Center & 6 & 16.7 & 2 & 0.0 & Cooper et al. (2000) \\
\hline Potter's Field & 8 & 0.0 & 5 & 0.0 & Tiné et al. (2002) \\
\hline
\end{tabular}

* Refers to the number of individual burials for which porotic hyperostosis or cribra orbitalia were observable out of the total burial population.

** Sample size for Phillips Memorial Cemetery is based on the total number of burials with human remains rather than the number of burials with observable elements.

although a smaller sample of usually partial skeletons recovered from burials at Phillips Memorial Cemetery in rural Galveston County, demonstrated the presence of the disorder (Dockall et al. 1996). This suggests the possibility of a genetic component as a causative factor.

\section{Infection}

Infection is intimately linked to nutrition because lowered nutrition levels compromise the immune system and leave an individual more susceptible to infection. In turn, nutrients necessary for growth or sustaining normal biological processes are diverted to enable the person to fight the infection, thereby creating a vicious cycle. Infections may also reflect poor sanitary conditions, limited access to medical care, or propensity for injury. If untreated, serious infections would have limited a person's ability to be economically productive.

Neither of the observable skeletons (both adults) from Pioneer Cemetery exhibited skeletal lesions indicative of an infection, but infections-whether caused by disease or trauma-are common in many other historic cemetery populations (Table 6.3). Acute infection is a possible cause of death for any of the three burials represented, and is particularly likely in the cases of the two younger people (Burials 1 and 4). If either of these people died of disease-related infections, there would not necessarily be any evidence on their bones. Many infections do not leave observable bone lesions, and people may

Table 6.3. Frequencies of skeletal infection among various historic cemetery samples

\begin{tabular}{lccl}
\hline Site & $\begin{array}{c}\text { No. of Observable } \\
\text { Individuals* }\end{array}$ & $\begin{array}{c}\text { Percent } \\
\text { Occurrence }\end{array}$ & Source \\
\hline Cedar Grove & 79 & 79.7 & Rose, ed. (1985) \\
Freedman's Cemetery & 693 & 63.8 & Tiné (2000) \\
Third New City Cemetery & 355 & 22.0 & Foster and Nance, eds. (2002) \\
Phillips Memorial & $43^{* *}$ & 25.6 & Dockall et al. (1996) \\
Dallas Convention Center & 4 & 75.0 & Cooper et al. (2000) \\
Potter's Field & 9 & 44.4 & Tiné et al. (2002)
\end{tabular}

* Refers to the number of individual burials for which evidence of skeletal infection was observable out of the total burial population.

** Sample size for Phillips Memorial Cemetery is based on the total number of burials with human remains rather than the number of burials with observable elements. 
die of an infection long before the skeletal system might be impacted. This is not to assume, however, that disease or disease-related infection was the cause of death for these two individuals, but this remains a distinct possibility given their young ages. For Burial 3, while some type of infectious disease could have been the cause of death, this person would have been vulnerable to many other disorders (e.g., heart disease, cancer) that are more common among middle-aged and elderly people.

Other disorders or traumas that leave no visible evidence on the skeletal remains cannot be discounted as cause of death for any of the Pioneer Cemetery individuals. However, examinations of historical data for the late 1800 s and early 1900s in Dallas (Tiné et al. 2002) and Houston (Foster and Nance eds. 2002) indicate that most deaths in these areas during this same time period resulted from infectious diseases or agents. Much of rural Brazoria County had a small, more-isolated population that was probably not as conducive to rapid person-toperson spread pathogens as urban areas. The rural people, however, were probably susceptible to pathogens spread by other means, such as insects and waterborne organisms. In contrast, people who lived in Brazoria may have been exposed to a wide variety of pathogens because of its location along a major transportation waterway.

Other skeletal samples from burial grounds of a similar time period typically demonstrate high frequencies of skeletal infection (see Table 6.3). The comparatively lower frequencies of infection seen at TNCC and Phillips Memorial Cemetery are probably due, at least in part, to poor skeletal preservation and representation. However, it might be expected that the Phillips Memorial population would have been less prone to some kinds of infections because of its rural setting. Nevertheless, both cemetery populations do contain a fair number of individuals with evidence of infection. Likewise, prevalence of infection seen among the smaller urban samples at DCC and Potter's Field might not reflect the true frequency of infection within the living population, but it does suggest that various types of infections were a serious problem. Elevated levels of skeletal infection are expected among the urban samples because of factors such as population aggregation, migration and introduction of new pathogens, and poor sani- tation. Cedar Grove Cemetery, on the other hand, has the highest frequency of skeletal infection of all the historic cemetery samples, and it seems to represent a biologically stressed and compromised population that was easily susceptible to infection.

\section{Trauma}

Skeletal trauma can reflect both accidental/occupational types of injuries as well as those that result from violence. Both forms of trauma carry economic, psychological, and social implications. Traumas may result in partial disability, with economic ramifications that involve a person's ability to work, the types of work available to that individual, and the duration of their economic viability. In the most extreme cases of trauma, total disability or death may occur. Any form of trauma evident in skeletal remains probably resulted in some type of psychological stress on the individual and their family. Evidence of interpersonal violence within a population is particularly significant because it reflects the stability of the families and communities represented.

Only the adult skeletons from Pioneer Cemetery were preserved well enough to permit observation for trauma. None was found, which is not surprising given the small sample size. Nevertheless, trauma was a common occurrence during this time, as seen in the contemporary cemetery samples (Table 6.4). Much of the variability in the trauma frequencies is due to differential bone preservation and the types of trauma that were scored by different investigators. For a rural, primarily agricultural population, the ubiquitous presence of large animals, the need to perform many tasks manually, and the frequent use of heavy machinery with few safety mechanisms were constant dangers. Although an ossified hematoma was observed on one urban DCC individual, this type of trauma was not as severe as the fractures and dislocations incurred by African Americans and poor whites who typically held more strenuous and dangerous occupations.

Evidence of weapon wounds was observed among the Phillips Memorial, Cedar Grove, TNCC, and Freedman's Cemetery samples. The timespan of these cemeteries coincides with the Reconstruction and Post-Reconstruction eras, and racism was a key, though not the only, reason 
Table 6.4. Frequencies of trauma among various historic cemetery samples

\begin{tabular}{lccl}
\hline Site & $\begin{array}{c}\text { No. of Observable } \\
\text { Individuals* }\end{array}$ & $\begin{array}{c}\text { Percent } \\
\text { Occurrence }\end{array}$ & Source \\
\hline Cedar Grove & 77 & 21.1 & Rose, ed. (1985) \\
Freedman's Cemetery & 422 & 30.8 & Tiné (2000) \\
Third New City Cemetery & 355 & $5.0 * *$ & Foster and Nance, eds. (2002) \\
Phillips Memorial & $43^{* * *}$ & 14.0 & Dockall et al. (1996) \\
Dallas Convention Center & 3 & 33.3 & Cooper et al. (2000) \\
Potter's Field & 7 & 14.3 & Tiné et al. (2002)
\end{tabular}

* Refers to the number of individual burials for which evidence of trauma was observable out of the total burial population.

** Statistic is for fractures only.

*** Sample size for Phillips Memorial Cemetery is based on the total number of burials with human remains rather than the number of burials with observable elements.

for lethal violence suffered by African Americans during this period (Prior and Schulte 2000). In addition, poverty and social disenfranchisement can cause despair, desperation, and escapist behaviors (e.g., the use of alcohol and drugs) that result in increased intragroup violence. Of the six historic cemetery samples listed in Table 6.4, evidence of interpersonal violence was absent only in the DCC and Potter's Field samples, and this is probably due at least somewhat to the small sample sizes.

\section{Degenerative Conditions and Biomechanical Stress}

Degenerative disorders are related to both age and biomechanical stress (related to movement of bones and joints). In some instances, trauma or other pathological conditions can accelerate degenerative processes, particularly when alignment of joint surfaces is altered, such as with a dislocation, or when one side of the body is favored because of pain or impaired mobility of the opposite side. Degenerative disorders can indicate activity patterns and workloads, and can reflect the biological and economic costs of such activities.

Among the two adults from Pioneer Cemetery, Burial 1, the young woman, showed no evidence of skeletal degeneration. Burial 3, the older woman, demonstrated mild to moderate expressions of osteoarthritis and vertebral osteophytosis. The vertebrae and spongy articular surfaces of this individual were generally poorly preserved, but the left side of the skeleton tended to preserve better than the right.
Therefore, although it was usually possible to determine if a particular bone was arthritic, it was not always possible to determine how much of the articular surface was affected or whether the condition was expressed bilaterally. With the exception of the distal ulnae and right radius, the articular surfaces of the arm bones were generally observable but gave no indication of arthritic lipping or pitting. The slightest bit of ridging was present on the articular margins of some of the hand phalanges and the joints of the lower body did exhibit osteoarthritis. In particular, articular surfaces of the left knee and ankle (the right were not observable) exhibited mild to moderate pitting and lipping. Very little of the vertebral column was preserved, although the centrum for the seventh cervical vertebra was present and exhibited compression and mild to moderate osteophytosis along the inferior and superior margins with the inferior aspect affected the most severely.

Based on the age estimate of the Burial 3 skeleton, the degree of degeneration is not excessive. It does indicate considerable use of the legs, probably because she had to walk everywhere, and either bending of the neck or carrying heavy loads on her head. She also exhibited noticeable development of muscle attachment sites in the upper body (inferior medial clavicle, deltoid tuberosity of the humerus, distal lateral humerus, supinator crest of the ulna, and brachialis insertion of the ulna) that are a response to repeated and prolonged activity including lifting, pushing, and pulling objects. The proximal hand phalanges demonstrated moderate development of the medial and lateral 
Table 6.5. Frequencies of degenerative disorders among adults from various historic cemetery samples

\begin{tabular}{lccl}
\hline Site & $\begin{array}{c}\text { No. of Observable } \\
\text { Individuals* }\end{array}$ & $\begin{array}{c}\text { Percent } \\
\text { Occurrence }\end{array}$ & Source \\
\hline Cedar Grove & 34 & 64.7 & Rose, ed. (1985) \\
Freedman's Cemetery & 319 & 91.5 & Tiné (2000) \\
Phillips Memorial & $43^{* *}$ & 51.2 & Dockall et al. (1996) \\
Dallas Convention Center & 4 & 100.0 & Cooper et al. (2000) \\
Potter's Field & 8 & 100.0 & Tiné et al. (2002) \\
\hline
\end{tabular}

*Refers to the number of individual burials for which evidence of degenerative disorders was observable out of the total burial population.

**Sample size for Phillips Memorial Cemetery is based on the total number of burials with human remains rather than the number of burials with observable elements.

sides of the palmar aspect of the hand phalanges where the sheaths for the tendons of the flexor muscles attach. This is consistent for activities that involve prolonged gripping of an object or manual manipulation. The temporal lines of the frontal and parietals were strongly developed, which suggests frequent clenching of the jaw. The lingual surfaces of the maxillary central incisors have worn horizontal U-shaped grooves that are rounded at the base of the groove and appear scooped out. The only other incisor present was the left maxillary lateral incisor, and its crown is half destroyed by a carious lesion. Therefore, no other incisors could be examined to better define the wear pattern and determine its cause. Considering the osteophytosis of the cervical vertebra and the hyperdeveloped temporal lines, it is possible that she routinely engaged in an activity that involved clamping an object between the front teeth and pulling it.

Degeneration of the movable joints and vertebral column is a common occurrence in the skeletons of historic burials (Table 6.5). Nearly all groups examined demonstrate degeneration most frequently in the joints of the lower body. This is logical because these joints bear the weight of the body. Also, walking great distances was probably a necessity for many people, especially the less financially advantaged.

Elevated rates of osteoarthritis and vertebral degeneration are expected for free blacks and poor whites because, as members of marginal social groups, they typically worked in lowpaying, labor-intensive occupations. The more advantaged DCC individuals also exhibited high frequencies of biomechanical stress, although all of the ageable adults were older than 30 years of age. Nevertheless, most of these individuals were quite robust, and muscle attachment hypertrophy was present and pronounced. While many of the DCC individuals may have held labor-intensive jobs in their less prosperous years that accelerated bone degeneration and muscle attachment development, these conditions likely occurred to some degree in almost all people who lived in the late nineteenth or early twentieth centuries because life was typically strenuous before the advent of many modern conveniences and labor-saving devices.

\section{Miscellaneous Skeletal Disorders}

Burial 3 demonstrated irregular, undulating, and, at times nodular, osseous deposits on at least one-half of the surface of the inner table of the frontal squamous. The deposits were bilateral, occurring on both sides of the frontal crest. This manifestation is consistent for hyperostosis frontalis interna (HFI), a condition that appears to be present more often in women than men and with stronger expression among females. It also appears to occur most often in individuals over the age of 40 (Hershkovitz et al. 1999). Despite much discussion in the anthropological and medical literature (e.g., Armelagos and Chrisman 1988; Hawkins and Martin 1965; Hershkovitz et al. 1999; Jaffe 1972; Salmi et al. 1962), the specific etiology and effects of the disorder remain to be determined. HFI has been associated with syndromes that include virilism and obesity in women, as well as mental disorders (Hawkins and Martin 1965). However, 
Hershkovitz et al. (1999) determined that HFI is an independent phenomenon, and other researchers have found that HFI can be asymptomatic (Jaffe 1972; Salmi et al. 1962). Although alterations in cranial vascularization and nerve function cannot be dismissed as possible contributing factors (Hershkovitz et al. 1999), the general consensus is that HFI is related to an imbalance or disturbance in the endocrine system. Hershkovitz et al. (1999) postulate that the condition arises from prolonged estrogen stimulus, thus explaining its greater presence in females and greater severity in older females. He also notes an increase in HFI among women born in the nineteenth and twentieth centuries who tended to live longer and have different reproductive patterns than their pre-industrial predecessors.

Burial 3, a 45-60-year-old female, conforms to the model of HFI as a disorder primarily present among post-menopausal women. Because the effects of the condition are largely not understood, it is difficult to determine if this individual suffered any physical or behavioral consequences. The condition, however, is not unknown among late nineteenth and early twentieth century burial samples. Individuals from the Cedar Grove Cemetery in Lafayette County, Arkansas (Rose ed. 1985); First African Baptist Church in Philadelphia, Pennsylvania (Rankin-Hill 1997); Mother UAME Cemetery in Wilmington, Delaware (Thomas et al. 2000); Third New City Cemetery in Houston, Texas (Foster and Nance eds. 2002); and Freedman's Cemetery (Condon et al. 1998) and Potter's Field in Dallas, Texas (Tiné et al. 2002), have been diagnosed with the condition. Most affected individuals were older females.

All of these historic skeletal samples mentioned above, except for Potter's Field, are composed of African Americans. The fact that historic African American burial samples outnumber and are larger in size (i.e., numbers of burials) than historic European American burial samples might account for apparent low frequency of HFI among historic white burials. Studies by Hershkovitz et al. (1999) indicate no statistically significant differences between African Americans and European Americans in the frequency of this condition, although African American women did tend to demonstrate a stronger correlation with age and severity of expression. The female from Potter's Field exhib- ited a milder expression of HFI compared to the black individuals observed in some of the other samples, which is somewhat consistent with this conclusion.

In sum, the osseous condition expressed on the frontal bone of Burial 3 has been observed at other historic cemeteries in Texas and elsewhere. It appears to be strongly associated with, and possibly a consequence of, the individual's age and sex. Whether she suffered any symptoms or the condition affected her quality of life is unknown.

\section{Dental Pathology}

Three types of dental pathology are examined in this section: carious lesions, abscesses, and antemortem tooth loss. Though they do not represent a strict cause-and-effect phenomenon, these disorders tend to be related in a progressive fashion and together provide a comprehension of diet, oral hygiene, and dental trauma for a given population. Dental caries is a process in which acid is produced by bacterial fermentation of carbohydrates from the diet. This acid destroys the hard tissues of the tooth and forms a cavity in the crown or root of the tooth (Hillson 1996; Larsen et al. 1991). Abscesses result in the localized destruction of alveolar bone. Periodontal abscesses are the consequence of infection outside the pulp cavity of the tooth (Ortner and Putchar 1981; Ruben et al. 1970), whereas periapical abscesses are the result of infection and the subsequent formation of pus in the root canal (Hillson 1996). The latter is associated with destruction of the tooth and exposure of the pulp cavity through carious activity, trauma, or rapid attrition. Tooth loss results from several causes: traumatic exfoliation; intentional extraction; or destruction of the alveolar bone or surrounding soft tissues (periodontal disease). This tissue destruction may be due to irritation or to certain metabolic deficiencies such as scurvy (Ortner and Putchar 1981). Age is another factor that affects periodontal bone loss, although it is not necessarily the primary cause (Hillson 1996).

Dental pathology is indicative of poor oral hygiene, a diet rich in carbohydrates, the absence of professional dental care, or any combination of these. The presence of abscesses or unfilled caries in an individual indicates that the condition was not treated, usually because of the 
lack of financial resources, the availability of a professional dentist to the region, or the typical human avoidance of the dentist.

Dental pathology was not excessive among the individuals from Pioneer Cemetery. No carious lesions were observed on the erupted deciduous teeth of Burial 4. Burial 1 demonstrated two small carious lesions, each on the occlusal surface of a maxillary molar. No abscessing or antemortem tooth loss occurred. Dental disease is age progressive, and Burial 3 exhibited the most extensive pathology. A large carious lesion was present on the distal crown of the right maxillary canine, which apparently spread to the mesial surface of the neighboring first premolar. Likewise, much of the mesial half of the left maxillary lateral incisor was destroyed by a cavity and a small carious lesion was present on the adjoining distal surface of the left maxillary central incisor. A final carious lesion was present on the distal cemento-enamel junction of the left mandibular first molar. Half of her teeth were missing postmortem which precluded observation for additional caries.

In Burial 3, alveolar bone was present for most of the teeth and only one remodeled socket, which indicates antemortem loss, was observed. No abscessing was evident. Three of the third molars were missing, but no alveolar bone was present. Though not related to diet or oral hygiene, the only remaining third molar-the left mandibular-was impacted, and the other third molars might have been as well. It is not known whether this condition caused any discomfort for the individual and affected her quality of life. Neighboring teeth appear to have been unaffected by the condition.

Dental pathology was common among most late-nineteenth and early-twentieth-century populations and is well represented in historic cemetery samples. Direct comparisons are problematic because of differences in the quantification methods different researchers use to document alveolar bone preservation, tooth recovery, caries, and other dental attributes. Time did not permit quantification of antemortem tooth loss of the Cedar Grove sample, but of 32 adults with adequate dental representation, all exhibited at least one carious lesion, and 22 had more than four carious teeth. Among 27 individuals with observable alveolar bone, eight exhibited abscesses, and three had more than one abscess (Rose ed. 1985). Low dental caries frequencies are reported for TNCC, where only 6.6 percent of all adult teeth had a carious lesion (Foster and Nance eds. 2002). Dockall et al. (1996:188) report that 25.3 percent of the observable teeth from Phillips Memorial Cemetery had at least one carious lesion. However, a single, anomalous individual is responsible for the elevated frequency, and the overall caries rate is considered low. The reduced caries frequencies among these latter two samples might be result of limited access to cariogenic foods such as refined sugars and flours. With a dental sample from only two adults, it is impossible to accurately assess the frequency of dental disease at Pioneer Cemetery.

Though available, specific data for dental disease were not within the scope of the Freedman's Cemetery study (Tiné 2000); however, cursory observation indicated that dental pathology was frequent and often extensive. In relation to the two small European American samples, the Pioneer Cemetery dentitions appear quite healthy. Two of three observable dentitions from the DCC sample indicated at least one carious lesion, and more than one tooth was affected per dentition (Cooper et al. 2000). Four individuals had sufficient alveolar bone to assess abscessing and antemortem tooth loss. One individual exhibited an abscess, and all four showed antemortem loss of at least one tooth. Three people lost more than one tooth. All four individuals were estimated to have been more than 30 years old at the time of death which possibly explains the higher frequencies.

The white paupers from Potter's Field also demonstrated high frequencies of dental pathology even among younger adults (Tiné et al. 2002). All eight observable adult dentitions indicate multiple carious lesions. One of five individuals exhibited alveolar abscesses, and six of seven exhibited antemortem tooth loss. Four had lost more than one tooth prior to death.

The causative mechanisms of dental pathology may have differed between these two groups. For instance, the paupers might have been more reliant on carbohydrate-rich diets that consisted of rice, beans, corn, and corn products, but the wealthier individuals from the DCC sample had greater access to cariogenic food products such as refined flour and sugar. Differences in oral hygiene practices cannot be completely ignored, either. Overall, reported dental pathology appears to have been higher 
in the Dallas area, for both poor and middleincome people, than it was in the parts of Texas closer to the Gulf Coast. This evidence may indicate differences in diet that were probably related, at least in part, to regionally-available food resources and not necessarily income. Marine and aquatic foods available from the river and coast might have provided coastal populations with a regular source of calcium, along with sufficient calories and nutrients to reduce the use of inexpensive cariogenic foods such as cornbased products.

No evidence of dental restorations or prosthetic devices was present at Pioneer Cemetery, but the small sample size is certainly a consideration. Even among the larger, historic samples (e.g., Freedman's Cemetery, Cedar Grove, and TNCC) evidence of this type of dental care is sporadic. Both the expense of restorative procedures and availability of professional dental care to African Americans near the turn of the twentieth century would explain the limited archeological evidence. It would be expected that rural areas such as Brazoria would offer less opportunity for such a service.

\section{SUMMARY}

A limited, nevertheless, valuable amount of information was gleaned from three individuals excavated from Pioneer Cemetery. Time period, location, and associated mortuary artifacts suggest that these African Americans were of low to modest economic standing. However, analysis of the human remains and associated material culture and comparison with other burial samples indicates that the Pioneer Cemetery group is not significantly different from other contemporary African American groups in Texas.

Despite the small sample size for Pioneer Cemetery, the presence of a young child and a young adult is consistent with mortality patterns from larger postemancipation African American burial samples. The presence of an older adult in the Pioneer Cemetery sample may be somewhat unusual. Both osteological and gravestone data indicate that several individuals buried at Pioneer Cemetery between 1899 and 1946 had survived past 50 years of age, and sometimes well into old-age. In contrast, skeletal samples of African Americans from Dallas and rural Arkansas suggest low frequencies of individuals who had lived beyond 40 years of age.

Indications of childhood stress were observed in the Pioneer sample, which conforms to both poor white and black skeletal samples of the late 1800 s and early 1900 s. No evidence of iron deficiency was detected at Pioneer. It is not known whether this is fortuitous, or perhaps these people had an adequate diet because they were able to exploit the local natural environment. In general, evidence of anemia among skeletal samples in Texas is low, although different mechanisms might have affected diet in urban and rural populations, and a genetic predisposition to sickle-cell trait might have resulted in a handful of anemia cases within the African American groups. Lower frequencies of dental pathology among the Pioneer burials and those from neighboring coastal counties might also be partially explained by regional differences in food sources. The coastal groups might have had fewer caries, for example, because they ate high-carbohydrate, cariogenic foods less frequently than noncoastal people.

Although skeletal infection is commonly observed in historic burial samples, no evidence was present among the Pioneer Cemetery burials. The extremely small sample size is certainly a factor, but it is possible that the rural population of Brazoria County might have been buffered against the high levels of infection reported in Texas cities and evident in urban burial samples. Nevertheless, acute infection is a strong possibility for cause of death for any of the three individuals, particularly the younger two. The presence of multiple enamel hypoplasias on the young woman's teeth suggests that she might have already been biologically compromised and was unable survive additional biological insult. Likewise, the young child and older woman represent age groups with typically lowered immunity.

No evidence of skeletal trauma was observed among the exhumed individuals at Pioneer Cemetery. Again, the extremely small sample may account for this absence, and trauma is represented in all other contemporary burial samples examined in this study (see Table 6.4). A fairly high frequency of trauma is expected among historic African Americans who typically worked at physically strenuous and dangerous occupations and were possibly at greater risk for violent and lethal trauma because of racial tensions of the time. 
Burial 3, a woman who died at 40 to 65 years of age, exhibited mild to moderate degrees of degeneration of the vertebrae and movable joints, along with moderate development of muscle attachment sites. This pattern of habitual biomechanical stress conforms to those observed among contemporary African American burial samples, reflecting a lifestyle that involved constant and physically strenuous manual labor for most people. As is true of many African Americans who died in the late nineteenth or early twentieth centuries, this woman worked hard all her life and may have spent a portion of her youth working as a slave. 



\section{SUMMARY AND SYNTHESIS}

\section{BIOARCHEOLOGICAL INVESTIGATIONS}

Pioneer Cemetery was established in 1888 when the property was purchased by the trustees of two African American churches in Brazoria, Texas, to serve as a burial ground for parishioners and other community members. Additional land was deeded in 1891, and a third church gained joint ownership (Dismukes and Bettis 2002:6, 13, 39-40, 46, 50). The earliest people buried in the cemetery were freedmen and their descendants. Although the earliest known date from a marked burial is 1899 , burials probably began to occur soon after the establishment of the cemetery, but most probably could not afford permanent markers for their loved ones at the time. Dates from extant gravestones indicate that the cemetery appears to have been regularly utilized into the 1940s. By this time, other burial grounds were probably available to the African American community, and the cemetery was probably perceived as being full. Nevertheless, occasional burials still occur, with the most recent marked burial dating to 2000 . The addition of more recent graves was made possible because a 1985 lawsuit allowed the cemetery to gain control over two lots that were thought to belong to the them (Dismukes and Bettis 2002:39-40).

Decline in the use of the burial ground appears to have occurred around 1939 when SH 332, which borders the west side of the cemetery, was constructed (Dismukes and Bettis 200:6, 39-40, 46). Improvements to widen this road (the existing hurricane evacuation route) have been the impetus for the current archeological investigations and a need to reconcile the past with the future. Of the six unmarked graves originally identified as being within the proposed construction right of way or very near it, only three required removal. One possible grave was examined but found to be a natural feature, while two other unmarked graves that barely intrude into the highway right of way were capped in concrete and marked by TxDOT for avoidance.

The three graves in the right of way were archeologically excavated and examined. These studies permitted a greater insight into the past. The three individuals were a 40-65-year-old woman, a young woman 17-23 years of age, and a 2-4-year-old child. Recovered artifacts suggest that the burials probably occurred early in the cemetery's existence as a burial ground, probably before or near the turn of the twentieth century, but perhaps as late as the 1920s. Their burials were modest and exhibited minimal hardware that was already out of style before the founding of the cemetery. Only one of these burials probably used a manufactured casket, while the other two had plain, most likely homemade, coffins. Financial limitations and limited availability of current mortuary hardware in the region are possible explanations. However, even among rural cemeteries of this time period, all but the most remote appear to have had access to a variety of ornamental burial hardware. Perhaps the black Brazorians at this time did not have any fraternal organizations or mutual-aid societies to assist with burial services, and individual families had to finance burials on their own when a loved one died. Such factors may account for the sparse and outdated funerary hardware and simple burial containers seen in these three burials.

Personal items associated with the three burials were relatively simple and consisted 
primarily of buttons. The two younger individuals appear to have been interred in burial gowns, while the older woman was buried in street clothes. The latter burial also differed from the other two in that she had a better (i.e., more modern and presumably more expensive) burial container with slightly more ornamentation. She also was buried with more personal items, including several pieces of jewelry that probably were sentimental to her but were readily available from retail catalogs of the period. Such jewelry would have been affordable to the mainstream public, yet some of the items-her gold wedding ring in particular-were probably a major financial investment for African Americans in turn-of-the-century Brazoria. While it is possible that the interment represents a slightly later burial (post 1900), when such items were more affordable, it does not explain the sparse and old-fashioned casket hardware.

Most historic burials from this time period indicate conservatism with respect to the type and value of personal items buried with a person. Such is the case for the two younger people at Pioneer Cemetery, whose burials were both simple and inexpensive. In contrast, the burial of the 40-65-year-old woman does not fit this pattern. Her burial represents a degree of respect and sentimentality perhaps paid only to older people who were prominent within their family and community. Because only a small percentage of graves at Pioneer Cemetery were marked at all, the fact that the manufactured headstones are predominantly for individuals over 50 years of age supports this hypothesis. Custom among many African Americans dictates a proper, if not elaborate, burial (Vlatch 1989), and this woman was probably buried in her finest attire in the best burial family and friends could afford. She was perhaps permitted an amount of respect and dignity that she may have been denied in life as a black woman in a white dominated society. Jamieson (1995:54-56) suggests that African American burials become Anglicized in the late nineteenth century in an attempt to mask the socioeconomic differences between blacks and whites.

Indications of possible grave offerings and homemade grave markers among the three burials excavated at Pioneer Cemetery suggest that although poor, the deceased were loved and mourned. Likewise, the presence of very mod- est burial container ornamentation indicates personal attention and sentiment despite the general poverty of the community. While it is far from certain, the presence of shell and a possible "killed" grave offering may reflect vestiges of ancient African traditions (Clow and Green 2000:454). Jamieson (1995:55) states that, ". . .African-American burials by the midnineteenth century, and in some cases well before that date, had become indistinguishable from the burials of any other ethnic group in America." While African American burials were undoubtedly changing throughout the nineteenth century, this statement is not entirely true. Evidence from Freedman Cemetery in Dallas indicates that a small portion of the 1,157 burials contain evidence that some African traditions may have survived into the twentieth century (Clow and Green 2000:454-457; Peter, Prior, Clow, and Green 2000:550-552).

Biologically, the remains of these three Pioneer Cemetery individuals reflect trends observed among other historic burial samples. In particular, childhood stress and mortality are apparent. Although not uncommon among Anglo American skeletal samples, lowered social and economic status as well as possible adjustments to independent living could have exacerbated these difficulties for African Americans. Despite the early deaths of the child and young adult excavated, the third individual survived to an advanced age. Data from extant headstones at Pioneer Cemetery indicate that at least a portion of the adult population enjoyed longevity, although the actual proportion of adults is not known.

Absence of dietary deficiencies among this sample suggests that diet was, for at least some, adequate, perhaps due to exploitation of the natural environment. Similarly, dental health appears better in this small coastal sample than in the more inland skeletal samples. This could indicate less reliance on inexpensive cariogenic foods, such as corn-based products, or diet supplementation with calcium-rich aquatic and possibly plant sources. However, reduced access to refined foods such as sugar and flour could also be a factor.

Despite generally high frequencies of skeletal infection within most historic burial samples, none was observed on the skeletons of the two adequately preserved individuals. Life in a rural environment might decrease exposure 
to infectious organisms. Nevertheless, a burial sample by its very nature represents deceased individuals who did not survive some particular stress. Although cause of death cannot be determined for any of the three excavated individuals, evidence of previous biological stress was noted, and the small sample contains immunologically vulnerable age groups (i.e., young and old) and suggests the possibility of death from acute infection.

With only two skeletons complete enough to be observed, lack of skeletal trauma within this sample is inconclusive with regard to the life quality of the larger cemetery population. However, the older woman exhibited evidence of joint degeneration and muscle attachment development indicative of a life of strenuous physical labor. Though not uncommon among skeletal samples from the late 1800s and early 1900 s, the social status of the Pioneer Cemetery population suggests that many were probably relegated to physically demanding occupations. It should also be noted that the older woman may have actually been a slave for part of her life. If she were 60 years old and died around 1890 , for example, she would have been born in 1830 and been a slave up to about age 35 .

\section{REBURIAL CEREMONY}

It is always unfortunate when people must be removed from what was hoped would be their final resting places. However, on occasion the needs of the living take precedence over those of the dead. The three graves within the TxDOT right of way for $\mathrm{SH} 332$ had to be moved. The current burial relocation activities were handled as sensitively as possible, and the number of burials removed was minimized. The remains of the three exhumed burials represent unidentified people who lived more than a century ago. The deaths of these people were acknowledged and mourned by the African American community long ago, but their grave locations and identities were forgotten over the past century. By taking the time to respectfully remove and examine the remains, many aspects of historic African American life in Brazoria were revealed, but the identities of these people remain a mystery.

Following the exhumation and analysis of the burials, all of the human remains and associated materials were placed in individual wooden reburial boxes. At the conclusion of the project, they were reinterred in an area within the cemetery and safely beyond the construction right of way. A memorial service was conducted, and it was attended by community members, descendants of people buried in the cemetery, members of the Brazoria County Historical Museum's cemetery committee, PAI and TxDOT archeologists, and regional TxDOT representatives (Figures 7.1 and 7.2). The service began with introductory remarks by Brazoria mayor Ken Corley. Reverends Ed Baker and Moran Collier, both African American ministers from local churches, presided over the service. Following the singing of Amazing Grace, bible passages were read, and the lives of the three unknown individuals were commemorated. The three caskets were then placed into the new grave, and the ceremony ended with the Lord's Prayer. It is hoped that by paying proper respect and documenting a small part of their stories, however incomplete, these unknown persons are given a voice in history. 


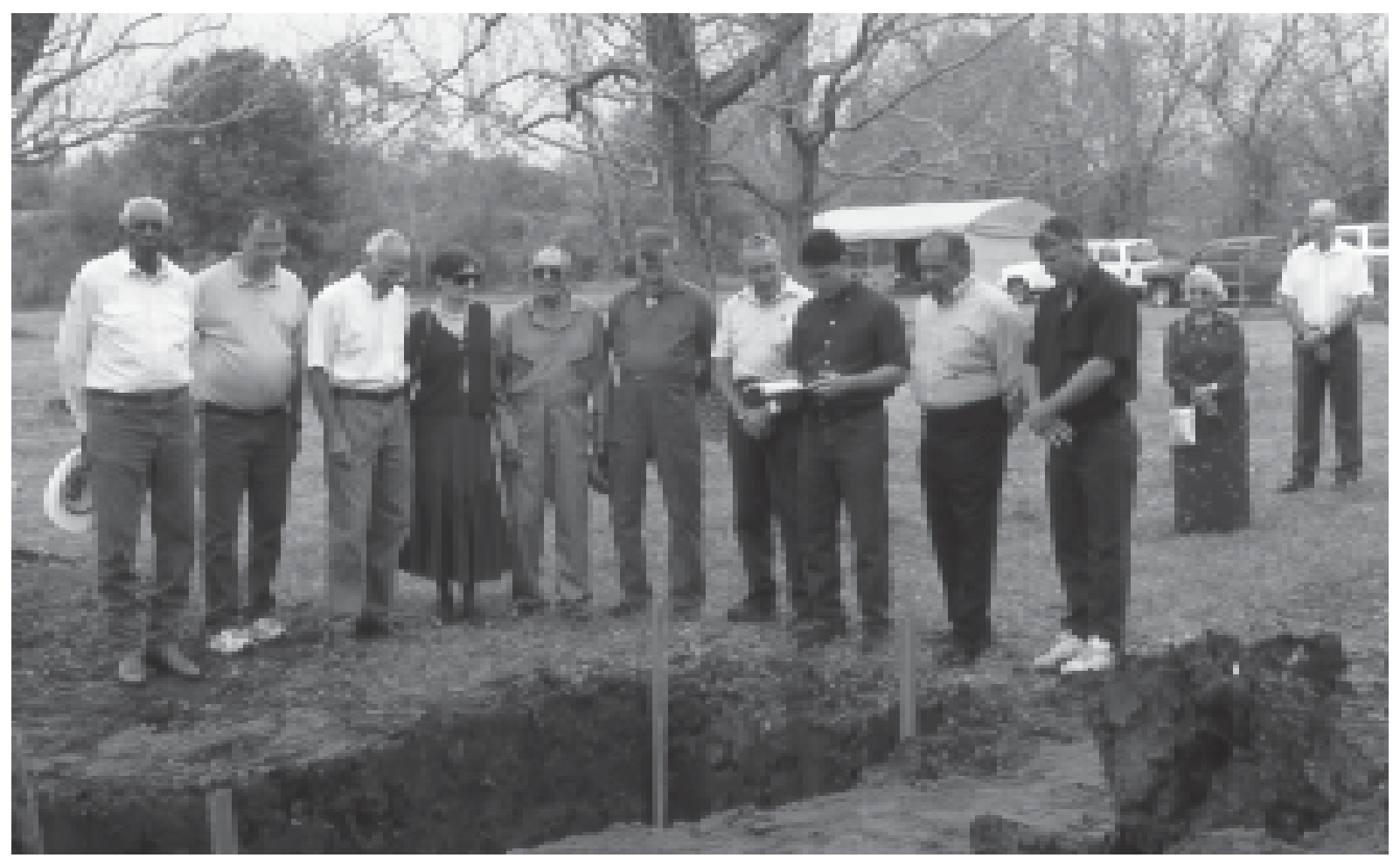

Figure 7.1. Some of the participants during the final prayer that concluded the reburial ceremony on April 4, 2003. From left to right are: Ed Wilkes, Billy Koenning, Max Royalty, Nancy Howard, Traversia Viola, Lou Harris, Roy Karl, Reverend Del Franklin, mayor Ken Corley, unidentified, Mrs. Traversia Viola, and unidentified. 


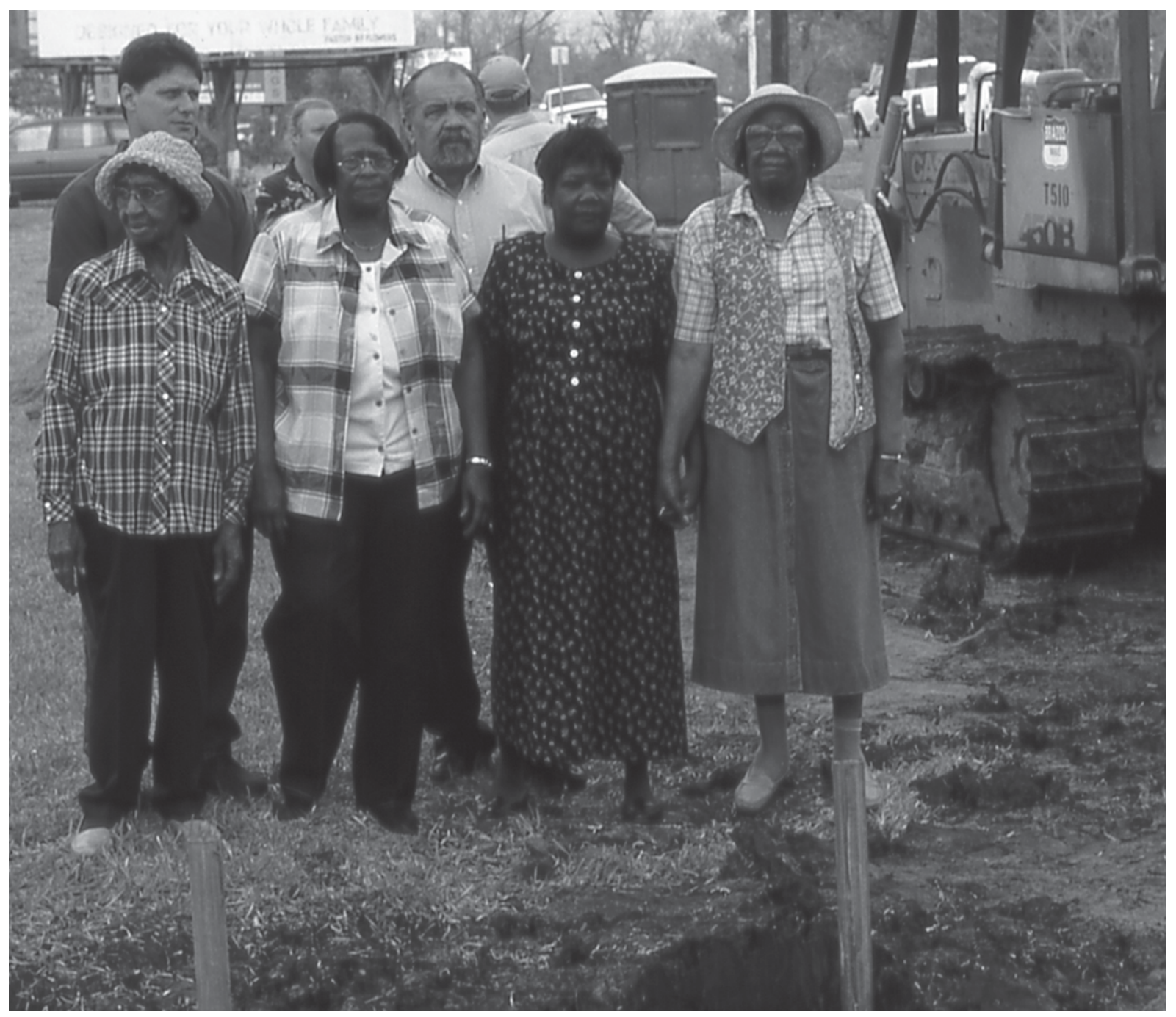

Figure 7.2. Four women who came to the reburial ceremony and have relatives buried in Pioneer Cemetery. From left to right in foreground are: Ethyl Flannel, Willie M. Curry, Ann E. Jammer, and Carrie Thomas. In the back are Reverend Del Franklin (right) and Brazoria mayor Ken Corley. 



\section{REFERENCES CITED}

Afrolumens

2003 Midland Cemetery: Aspects of African American Burial Traditions at Midland. Web gallery at Afrolumens: Central Pennsylvania African American History. Available from "http://www.afrolumens.org/ rising_free/midland2.html" [Accessed July 3, 2003].

Angel, J. Lawrence

1969 The bases of paleodemography. American Journal of Physical Anthropology 30:425438.

Armelagos, George J., and O. Donald Chrisman 1988 Hyperostosis frontalis interna: a Nubian case. American Journal of Physical Anthropology 76:25-28.

Aronow, Saul

1981 Surface Geology. In Soil Survey of Brazoria County, Texas, pp. 79-82. The U.S. Department of Agriculture, Soil Conservation Service, in cooperation with the Texas Agricultural Experiment Station.

Aufderheide, Arthur C., and Conrado RodríguezMartín

1998 The Cambridge Encyclopedia of Human Paleopathology. Cambridge University Press, Cambridge.

Baker, Scott J., George W. Gill, and David A. Kieffer 1990 Race and Sex Determination from the Intercondylar Notch of the Distal Femur. In Skeletal Attribution of Race: Methods for Forensic Anthropology, edited by George W. Gill and J. Stanley Rhine, pp. 91-97. Anthropological Paper No. 4. Maxwell Museum of Anthropology, Albuquerque, New Mexico.

Barnes, Virgil E.

1982 Geologic Atlas of Texas, Houston Sheet (Revised). Bureau of Economic Geology, University of Texas at Austin.

Bass, William M.

1995 Human Osteology: A Laboratory and Field Manual. Fourth edition. Missouri Archaeological Society, Columbia.
Baynes, R. D., and T. H. Bothwell

1990 Iron deficiency. Annual Review of Nutrition 10:133-144.

Bell, Edward L.

1990 The historical archaeology of mortuary behavior: coffin hardware from Uxbridge, Massachusetts. Historical Archaeology 24(3):54-78.

Bomar, George W.

1983 Texas Weather (New Edition, 1990). University of Texas Press, Austin.

Brooks, Sheila, and Judy M. Suchey

1990 Skeletal age determination based on the os pubis: a comparison of the AcsadiNemeskeri and Suchey-Brooks methods. Human Evolution 5(3):227-238.

Brothwell, Don R.

1981 Digging Up Bones. 3rd ed. Cornell University Press, Ithaca.

Bryant, Allison D.

1989 Odd Fellowship and craft masonry. The Philaletes, Vol. XLII, Number 1.

Buckberry, J. L., and A. T. Chamberlain

2002 Age estimation from the auricular surface of the ilium: a revised method. American Journal of Physical Anthropology 119:231-239.

Buikstra, Jane E., and Douglas H. Ubelaker (editors) 1994 Standards for Data Collection from Human Skeletal Remains. Research Series No. 44.Arkansas Archeological Survey, Fayetteville.

Burkholder, Nanetta K., and Louis Benefiel

1991 Tombstone Inscriptions from some Cemeter ies of Brazoria County, Texas. Brazosport Genealogical Society, Lake Jackson, Texas.

Burnet, Macfarlane, and David O. White

1972 Natural History of Infectious Disease. Cambridge University Press, London.

Chicora Foundation, Inc.

1996 What is the History of African American Cemeteries? In Grave Matters: The Preservation 
of African American Cemeteries, booklet by the Chicora Foundation, Inc., Columbia South Carolina. Web exhibit on the South Carolina Information Highway, SCIway, LLC.Available from "http://www.sciway.net/ hist/chicora/gravematters-1.html" [Accessed July 8, 2003].

Clow, Charles M., and Melissa M. Green

2000 Grave Goods and Mortuary Practices. In Freedman's Cemetery: A Legacy of a Pioneer Black Community in Dallas, Texas, vol. 2, edited by Duane E. Peter, Marsha Prior, Melissa M. Green, and Victoria G. Clow, pp. 449-460. Special Publications No. 6. GeoMarine, Inc., Plano, Texas. Environmental Affairs Division, Texas Department of Transportation, Austin. Archeology Studies Program Report No. 21.

Condon, Cynthia G., Joy L. Becker, Heather J. R. Edgar, James M. Davidson, Jeurena R. Hoffman, Patrcia Kalima, Daniel Kysar, Susan Moorhead, Victoria M. Owens, and Keith Condon

1998 Freedman's Cemetery: Site 41DL316, Dallas, Texas, Assessments of Sex, Age at Death, Stature, and Date of Interment for Excavated Burials. Report No. 9. Archeology Studies Program, Environmental Affairs Division, Texas Department of Transportation, Austin.

Cooper, Judy H., Angela L. Tiné, Marsha Prior, Charles M. Clow, David Shanabrook, and Edward Salo

2000 Cultural Resources Investigations at Dallas Convention Center and Pioneer Cemetery, Dallas, Texas. Miscellaneous Reports of Investigations No. 205. Geo-Marine, Inc., Plano, Texas.

Craig, Joseph, and Clark S. Larsen

1993 Life and Death on the Illinois Prairie: Archaeological and Osteological Investigations at the Cross Cemetery, Springfield, Illinois. Hanson Engineers, Inc. Submitted to Roosevelt National, Springfield, Illinois.

Davidson, James M.

2000 The Development of Freedman's Cemetery. In Freedman's Cemetery: A Legacy of a Pioneer Black Community in Dallas, Texas, vol. 2, edited by Duane E. Peter, Marsha Prior, Melissa M. Green, and Victoria G. Clow, pp. 233-395. Special Publications No. 6. GeoMarine, Inc., Plano, Texas. Submitted to Environmental Affairs Division, Texas Department of Transportation, Austin.
Archeology Studies Program Report No. 21.

Dismukes, Diane C., and Allen C. Bettis Jr.

2002 Historical and Archeological Investigation of the SH 332 Crossing of the Brazos River, Brazoria County, Texas. Texas Department of Transportation, Austin.

Dockall, Helen D., Joseph F. Powell, and D. Gentry Steele

1996 Home Hereafter: An Archaeological and Bioarchaeological Analysis of an Historic African-American Cemetery (41GV125). Reports of Investigations No. 5. Center for Environmental Archaeology, Texas A\&M University, College Station.

Fairbanks, V. F., and E. Beutler

1972 Erythrocyte Disorders. In Haematology, edited by W. Williams, pp. 3050-3170. McGraw-Hill, New York.

Fontana, B. L., and J. C. Greenleaf

1962 Johnny Ward's Ranch: a study in historic archaeology. The Kiva 28(1-2):1-115.

Forstall, Richard L. (compiler and editor)

1995 Population of Counties by Decennial Census: 1900 to 1990. Compiled and edited by Richard L. Forstall, Population Division, U.S. Bureau of the Census, Washington, D.C.Available from "http://www.census.gov/ population/cencounts/tx190090.txt” [Accessed July 2, 2003].

Foster, Eugene, and Linda A. Nance (editors)

2002 Archaeological Investigation Report: Allen Parkway Village, 41HR886, Houston, Harris County, Texas. Document No. 020018. PBS\&J, Austin.

Fox, Anne A.

1984 A Study of Five Historic Cemeteries at Choke Canyon Reservoir, Live Oak and McMullen Counties, Texas. Choke Canyon Series, vol. 9. Center for Archaeological Research, University of Texas at San Antonio.

Garrow, Patrick H., and Steven A. Symes

1987 The Big Lazer Creek Unmarked Cemetery: A Multidisciplinary Investigation. Garrow and Associates, Atlanta. Submitted to Georgia Department of Natural Resources.

Gibbs, Tyson, Kathleen Cargill, Leslie S. Lieberman, and Elizabeth Reitz

1980 Nutrition in a slave population: an anthropological examination. Medical Anthropology (2):173-262. 
Gill, George W., and Stanley Rhine

1990 Skeletal Attribution of Race: Methods for

Forensic Anthropology. Papers No. 4. Maxwell Museum of Anthropology, University of New Mexico, Albuquerque.

Goodman, Alan H.

1994 Cartesian Reductionism and Vulgar Adaptationism: Issues in the Interpretation of Nutritional Status in Prehistory. In Paleonutrition: The Diet and Health of Prehistoric Americans, edited by K. D. Sobolik, pp. 163-177. Occasional Paper No. 22. Center for Archaeological Investigations, Southern Illinois University, Carbondale.

Goodman, Alan H., and Jerome C. Rose

1991 Dental Enamel Hypoplasias as Indicators of Nutritional Status. In Advances in Dental Anthropology, edited by M. A. Kelley and C. S. Larsen, pp. 279-293. Wiley-Liss, New York.

Goodman, Alan H., George J. Armelagos, and Jerome C. Rose

1980 Enamel hypoplasias as indicators of stress in three prehistoric populations from Illinois. Human Biology 52:515-528.

Habenstein, Robert W., and William M. Lamers

1995 The History of American Funeral Directing. 3rd ed. Revised and edited by H. C. Raether, National Funeral Directors Association, Milwaukee.

Hacker-Norton, Debi, and Michael Trinkley

1984 Remember Man Thou Art Dust: Coffin

Hardware of the Early Twentieth Century. Research Series 2. Chicora Foundation, Columbia, South Carolina.

Hallstein, Anna

2002 Brazoria, Texas. In The Handbook of Texas Online. Available from "http://www. tsha.utexas. edu/handbook/online/articles/ view/BB/hgb10.html" [Accessed July 1, 2003].

Hawkins, T. D., and L. Martin

1965 Incidence of hyperostosis frontalis interna in patients at a general hospital and at a mental hospital. Journal of Neurology, Neurosurgery, and Psychiatry 28:171-174.

Hershkovitz, Israel, Charles Greenwald, Bruce M. Rothschild, Bruce Latimer, Oliver Dutour, Lyman M. Jellema, and Susanne WishBaratz
1999 Hyperostosis frontalis interna: an anthropological perspective. American Journal of Physical Anthropology 109:303-325.

Hillson, Simon

1996 Dental Anthropology. Cambridge University Press, Cambridge.

Houghton, Philip

1974 The relationship of the pre-Auricular groove of the ilium to pregnancy. American Journal of Physical Anthropology 41:381-390.

1975 The bony imprint of pregnancy. New York Academic Medical Bulletin 51:655-661.

Howard, Nancy

2003 List of Persons Buried in the Pioneer Cemetery, Brazoria County, Texas. Compiled by the Cemetery Committee for the Brazoria County Historical Museum.

Huss-Ashmore, Rebecca, Alan H. Goodman, and G. J. Armelagos

1982 Nutritional Inference from Paleopathology. In Advances in Archaeological Method and Theory, vol. 5, edited by M. B. Schiffer, pp. 395-474. Academic Press, New York.

Jaffe, H. L.

1972 Metabolic, Degenerative, and Inflammatory Diseases of Bones and Joints. Lea and Febiger, Philadelphia.

Jamieson, Ross W.

1995 Material culture and social death: AfricanAmerican burial practices. Historical Archaeology 29(4):39-58.

Jordan, Terry G.

1982 Texas Graveyards: A Cultural Legacy. University of Texas Press, Austin.

Katz, Darryl, and Judy M. Suchey

1986 Age determination of the male os pubis. American Journal of Physical Anthropology 69:427-435.

Kiple, Kenneth F., and Virginia H. King

1981 Another Dimension to the Black Diaspora: Diet, Disease, and Racism. Cambridge University Press, Cambridge.

Kleiner, Diana J.

2002 "Brazoria County." The Handbook of Texas Online. Available from "http://www. tsha.utexas.edu/handbook/online/articles/ view/BB/hcb12.html" [Accessed May 15, 2003]. 
Krogman, Wilton M., and Mehmet Y. Iscan 1986 The Human Skeleton in Forensic Medicine. 2nd Edition. Charles C. Thomas, Springfield, Illinois.

Lang, K. A.

1984 Coffins and Caskets: Their Contribution to the Archeological Record. Unpublished Master's thesis, Department of Sociology, Anthropology, and Criminal Justice Studies. University of Idaho, Boise.

Landtech Consultants, Inc.

1999 Plat map entitled: "Boundary Survey of Pioneer Cemetery being Lots 3, 4, 9, 10, 11, and Part of Lots 5, and 8, Block 42, Old Townsite of Brazoria, Texas in the Stephen F. Austin League. Abstract No. 20, Brazoria County, Texas." Prepared for the Texas Department of Transportation by Landtech Consultants, Inc., Houston, Texas. Map Control No. 0847, Section No. 03, Job No. 029, Sheet No. 1.

Larsen, Clark S., Rebecca Shavitt, and Mark C. Griffin 1991 Dental Caries Evidence for Dietary Change: An Archaeological Context. In Advances in Dental Anthropology, edited by M. A. Kelley and C. S. Larsen, pp. 179-202. Wiley-Liss, Inc., New York.

Lebo, Susan A.

1988 An Archaeological and Bioarchaeological Perspective: The Tucker (41DT104) and Sinclair (41DT105) Cemeteries of Delta County, Texas. Institute of Applied Sciences, University of North Texas, Denton. Submitted to the U.S. Army Corps of Engineers, Fort Worth District.

Liebel, R. L., E. Pollitt, I. Kim, and F. Viter

1982 Studies regarding the impact of micronutrient status on behavior in man: iron deficiency as a model. American Journal of Clinical Nutrition 35:1211-1221.

Lovejoy, C. Owen, Richard S. Meindl, Thomas R. Pryzbeck, and Robert P. Mensforth

1985 Chronological metamorphosis of the auricular surface of the ilium: a new method for the determination of adult skeletal age at death. American Journal of Physical Anthropology 68:15-28.

Lunt, Roger C., and David B. Law

1974 A review of the chronology of calcification of deciduous teeth. Journal of the American Dental Association 89:599606.
Luscomb, Sally C.

1992 The Collector's Encyclopedia of Buttons. Schiffer Publishing, West Chester, Pennsylvania.

Meindl, Richard S., and C. Owen Lovejoy

1985 Ectocranial suture closure: a revised method for the determination of skeletal age at death based on the lateral anterior sutures. American Journal of Physical Anthropology 68:57-66.

Montgomery Ward \& Co.

1894-1895 Catalogue \& Buyers' Guide No. 56, Fall \& Winter. Montgomery Ward \& Co., New York.

1895 Catalogue and Buyers' Guide No. 57, Spring and Summer. Dover Publications, Inc., New York.

Moore-Jansen, Peer H., and Richard L. Jantz

1989 Data Collection Procedures for Forensic Skeletal Material. Report of Investigations No. 48. Forensic Anthropology Center, Department of Anthropology, University of Tennessee, Knoxville.

Moorees, C. F. A., E. A. Fanning, and E. E. Hunt Jr. 1963 Formation and resorption of three deciduous teeth in children. American Journal of Physical Anthropology 21:205-213.

Nelson, Lee H.

1968 Nail Chronology as an Aid to Dating Old Buildings. Technical Leaflet 48. History News Vol. 24, No. 11. American Association for State and Local History, Nashville.

Noël Hume, Ivor

1983 Martin's Hundred: The Discovery of a Lost Colonial Virginia Settlement. Dell Publishing Co., Inc., New York.

Ortner, Donald J., and Walter G. J. Putschar

1981 Identification of Pathological Conditions in Human Skeletal Remains. Smithsonian Contributions to Anthropology Number 28. Smithsonian Institution Press, Washington, D.C.

Owens, Victoria M.

2000 Personal, Clothing, and Miscellaneous Items Associated With Excavated Burials. In Freedman's Cemetery: A Legacy of a Pioneer Black Community in Dallas, Texas, vol. 2, edited by Duane E. Peter, Marsha Prior, Melissa M. Green, and Victoria G. Clow, pp. 409-447. Special Publications 
No. 6. Geo-Marine, Inc., Plano, Texas. Environmental Affairs Division, Texas Department of Transportation, Austin. Archeology Studies Program Report No. 21.

Owsley, Douglas W., Charles E. Orser, Robert Montgomery, and Claudia C. Holland

1985 An Archaeological and Physical Anthropological Study of the First Cemetery in New Orleans, Louisiana. Department of Geography and Anthropology, Louisiana State University, Baton Rouge.

Panati, Charles

1989 [1987] Panati's Extraordinary Origins of Everyday Things. Harper and Row, New York.

Peter, Duane E., Marsha Prior, Victoria G. Clow, and Melissa M. Green

2000 Freedman's Cemetery: A Symbol of Perseverance in the Face of Adversity. Section IV in Freedman's Cemetery: A Legacy of a Pioneer Black Community in Dallas, Texas, edited by Duane E. Peter, Marsha Prior, Melissa M. Green, and Victoria G. Clow. 2 vols. Special Publications No. 6. Geo-Marine, Inc., Plano, Texas. Environmental Affairs Division, Texas Department of Transportation, Austin. Archeology Studies Program Report No. 21.

Peter, Duane E., Marsha Prior, Melissa M. Green, and Victoria G. Clow (editors), with contributing authors Charles M. Clow, Victoria G. Clow, James M. Davidson, Melissa M. Green, Victoria Owens, Marsha Prior, Terry A. Schulte, and Angela Tiné

2000 Freedman's Cemetery: A Legacy of a Pioneer Black Community in Dallas, Texas. 2 vols. Special Publications No. 6. Geo-Marine, Inc., Plano, Texas. Environmental Affairs Division, Texas Department of Transportation, Austin. Archeology Studies Program Report No. 21.

Pickett, Joseph P., David R. Pritchard, and David M. Weeks

1997 American Heritage College Dictionary, Third Edition. Houghton Mifflin Company, Boston.

Powell, Leah C., and Helen D. Dockall

1995 Folk narratives and archaeology: an African-American cemetery in Texas. Journal of Field Archaeology 22(3):349-353.

Prior, Marsha, and Terry A. Schulte

2000 Freedman's Town/North Dallas: The Convergence and Development of an African
American Community. In Freedman's Cemetery: A Legacy of a Pioneer Black Community in Dallas, Texas, vol. 1, edited by Duane E. Peter, Marsha Prior, Melissa M. Green, and Victoria G. Clow, pp. 69-116. Special Publications No. 6. Geo-Marine, Inc., Plano, Texas. Environmental Affairs Division, Texas Department of Transportation, Austin. Archeology Studies Program Report No. 21.

Rankin-Hill, Leslie M.

1997 A Biohistory of 19th-Century Afro-Americans: The Burial Remains of a Philadelphia Cemetery. Bergin and Garvey, Westport, Connecticut.

Rhine, Stanley

1990 Non-Metric Skull Racing. In Skeletal Attribution of Race: Methods for Forensic Anthropology, edited by George W. Gill and Stanley Rhine, pp. 9-20. Maxwell Museum of Anthropology Papers No. 4. University of New Mexico, Albuquerque.

Rose, Jerome C. (editor)

1985 Gone to a Better Land: A Biohistory of a Rural Black Cemetery in the Post-Reconstruction South. Research Series No. 25. Arkansas Archaeological Survey, Fayetteville.

Ruben, M. P., H. M. Goldman, and S. M. Schulman 1970 Diseases of the Periodontium. In Thoma's Oral Pathology, edited by R. J. Gorlin and H. M. Goldman, pp. 394-444. C. V. Mosby Company, St. Louis.

Russell and Erwin Manufacturing Company 1980 [1865] Illustrated Catalogue of American Hardware of the Russell and Erwin Manufacturing Company. An Unabridged Reprint of the 1865 Edition. Association for Preservation Technology.

Salmi,A.,A. Voutilainen, L. R. Hosti, and C. E. Unnerus 1962 Hyperostosis cranii in a normal population. American Journal of Roentgenology 87:1032-1040.

Savitt, Todd L.

1988 Slave Health and Southern Distinctiveness. In Disease and Distinctiveness in the American South, edited by T. L. Savitt and J. H. Young, pp. 120-153. University of Tennessee Press, Knoxville.

Schour, I., and M. Massler

1941 The development of the human dentition. 
Journal of the American Dental Association 28:1153-1160.

Sears, Roebuck and Co., Inc.

1897 Catalogue No. 104, edited by Fred I. Israel. Reprinted in 1993 by Chelsea House Publishers, New York.

1902 Catalogue No. 111. Reprinted in 1993 by Grammercy Books, New York.

1906 Catalogue No. 116. Sears, Roebuck and Company, Chicago.

19271927 Edition of The Sears, Roebuck Catalogue. Reprinted in 1970. Sears, Roebuck and Company, Chicago.

Stewart, T. D.

1979 Essentials of Forensic Anthropology. Charles C. Thomas, Springfield, Illinois.

Stuart-Macadam, P. L.

1989 Nutritional Deficiency Diseases: A Survey of Scurvy, Rickets, and Iron-Deficiency Anemia. In Reconstruction of Life from the Skeleton, edited by M. Y. Iscan and K. A. R. Kennedy, pp. 201-222. Wiley-Liss, Inc., New York.

Symes, Steven A., and Richard L. Jantz

1983 Discriminant Function Sexing of the Tibia. Paper presented at the 35th Annual Meeting of the American Academy of Forensic Sciences, Cincinnati, Ohio.

Thomas, Ronald A., Betty C. Zebooker, Christopher M. Hazel, and David L. Weinberg (with contributions by Arthur Washburn, Thomas A. J. Crist, and Megan Springate)

2000 Archeological Investigations at the Mother UAME Church Cemetery (7NC-E-132) Wilmington, Delaware. CRS \# N-13, 523. MAAR Associates, Inc., Newark, Delaware.

Tiné, Angela L.

2000 Understanding Life and Death Through Freedman's Cemetery: A Comparative Bioarcheological Study of African American Health. In Freedman's Cemetery: A Legacy of a Pioneer Black Community in Dallas, Texas, vol. 2, edited by Duane E. Peter, Marsha Prior, Melissa M. Green, and Victoria G. Clow, pp. 461-517. Special Publications No. 6. Geo-Marine, Inc., Plano, Texas. Environmental Affairs Division, Texas Department of Transportation, Austin. Archeology Studies Program Report No. 21.
Tiné, Angela L., Judy H. Cooper, and Michelle Wurtz 2002 Archeological and Bioarcheological Investigations at Potter's Field / Greenwood Cemetery Along Clyde Lane, Dallas, Texas. GeoMarine, Inc., Miscellaneous Reports of Investigations Number 241.

Todd, T. W.

1920 Age changes in the pubic bone, I: the white male pubis. American Journal of Physical Anthropology 3:285-334.

1921 Age changes in the pubic bone, II: the pubis of the male negro-white hybrid; III: the pubis of the white female; IV: the pubis of the female negro-white hybrid. American Journal of Physical Anthropology 4:1-70.

Ubelaker, Douglas H.

1989 Human Skeletal Remains: Excavation, Analysis, Interpretation. 2nd ed. Taraxacum, Washington.

Ullrich, Herbert

1975 Estimation of fertility by means of pregnancy and childbirth alterations at the pubis, the ilium, and the sacrum. Ossa 2:23-39.

University of Virginia

1998 University of Virginia Geospatial and Statistical Data Center. United States Historical Census Data Browser. University of Virginia. Available from "http://www.fisher.lib.virginia.edu/census/" [Accessed July 2, 2003].

United States Department of Agriculture

1981 Soil Survey of Brazoria County, Texas. The U.S. Department of Agriculture, Soil Conservation Service, in cooperation with the Texas Agricultural Experiment Station.

Vargas, L.L.C.

1996 Brazoria, SW, Digital Orthophoto Quarter Quadrangle, No. 2995604, January 23, 1995. Texas Natural Resource Information System, Vargis, L.L.C. Herndond, Virginia. Available from "http://www.tnris.state.tx.us/ index" [Accessed March 7, 2003].

Vlatch, John M.

1978 The Afro-American Tradition in Decorative Arts. Cleveland Museum of Art, Cleveland.

1989 Funerary Customs, Black. In Encyclopedia of Southern Culture, edited by C. R. Wilson, W. Ferris, A. J. Abadie, and M. L. Hart, pp. 161-162. University of North Carolina Press, Chapel Hill. 
Webb, Patricia A. O., and Judy M. Suchey

1985 Epiphyseal union of the anterior illiac crest and medial clavicle in a modern multiracial sample of American males and females. American Journal of Physical Anthropology 68:457-466.

Weber, Stacy

2003 African-American Cemeteries: Significance. Online exhibit on the Tennessee Civil War National Heritage Area website, Center for Historic Preservation, Middle Tennessee State University. Available from "http:// www.histpres.mtsu.edu/tncivwar/aacem/ significance.html" [Accessed July 3, 2003].

Wells, Tom

1998 Nail chronology: the use of technologically derived features. Historical Arche- ology 32(2):78-99.

Wood, James W., George R. Milner, Henry C. Harpending, and Kenneth M. Weiss

1992 The osteological paradox: problems of inferring prehistoric health from skeletal samples. Current Anthropology 33(4):343-370.

Wright, Cheryl

1994 "Oral History Information: Birth, Death, and Everything in Between." In I Heard it Through the Grapevine: Oral Tradition in a Rural African American Community in Brazoria County, Texas. Online version of MA Thesis, Department of Anthropology, University of Houston. Available from "http://www.webarchaeology.com/html/ cheroral.htm\#BURIALS" [Accessed July 2, 2003]. 
APPENDIX A: Glossary of Technical Terms 
NOTE: This appendix defines the most common technical terms associated with the archeological recovery, analysis, and interpretation of human remains from historic graves. No attempt is made to define all of the medical and osteological terms used in this report.

Age Determination: Estimation of age at death, usually in years, of an individual through growth and development-related markers in the human skeleton, such as the formation and eruption of teeth or fusion of the ends of long bones.

Bioarcheology: A discipline that emphasizes "the human biological component of the archeological record" (Clark Spencer Larsen, 1992, Bioarcheology: Interpreting Behavior from the Human Skeleton, p. 3). In studies of historic cemeteries, this entails the analysis of any human remains exhumed from the cemetery and the incorporation of this information into the larger set of information gathered from the cemetery, such as personal effects, coffin type, and mortuary hardware.

Biological Affinity and Ethnicity: In osteology, biological affinity refers to the geographic ancestry of an individual as assessed by distinctive and inherited traits in the skeleton. Sometimes referred to as "race." Ethnicity is a broader term that encompasses biological affinity as well as cultural and social characters that typify an individual and the group to which they belong.

Biomechanical Stress: In osteology, refers to the demands placed on bone by various activities engaged in by the individual during their lifetime. An example of biomechanical stress might be the strain on the bones of the legs of an individual who runs on a regular basis.

Burial: see Interment

Casket: see Coffin

Coffin vs. Casket: Two types of burial containers used to bury people. A coffin is six-sided, or hexagonal, in shape and widest at the shoulders. A casket is four-sided, or rectangular in shape.

Cranial Measurements: Measurements taken between various landmarks on the human skull, usually used to determine such things as sex, biological affinity, etc.

Cribra orbitalia: A pathological lesion, usually associated with iron-deficiency anemia, found on the upper part of the eye orbits on the skull in humans.

Degenerative Disorder: In osteology, this typically refers to conditions in bone due to the aging process and biomechanical stress that result in a change in the normal structure and mass of bone. Generally loss of bone is the primary indicator, although some new bone growth may also occur as compensation for the loss. An example of a degenerative disorder in the skeleton is osteoarthritis.

Demography: The study of human populations, particularly in relation to size, density, distribution, and age structure.

Dental Inventory: In osteological analyses, this typically refers to an inventory of the teeth present in the skeleton of one individual.

Enamel Hypoplasia: A line or pit visible on the enamel of a tooth, associated with metabolic disturbance, often caused by sickness or nutritional deficiency, during childhood, the time the tooth was forming.

Ethnicity: see Biological Affinity

Exhume: To remove a burial from the ground. 
Infection: Pathological condition in the body caused by the presence of agents such as bacteria. In bone, infection may be evident either through the presence of abnormal, new bone formation or destruction of the bone.

Interment: The burial of an individual, including the physical remains and the burial container.

Metric Attributes: Aspects of the human skeleton that can be measured, such as the length of a longbone or the width of the skull.

Mortuary Hardware: Items used in the construction of a coffin or casket, such nails, tacks, thumbscrews, and handles, and the items used to decorate the coffin or casket, such as nameplates.

Nonmetric Attributes: Morphological characters of the human skeleton that are not measured, but are described or recorded in terms of their presence or absence. Examples include the type of cusp patterns on molars and the presence or absence of extra bones in the cranium. Some nonmetric attributes are thought to be at least partly inherited.

Osteology: The study of bone and the skeleton.

Paleopathology: The study of diseases and their patterning in past populations.

Personal Effects: Items belonging to an individual that are buried with that individual. Items commonly found in historic graves include buttons from the clothing the individual was wearing when they were buried, hairpins, and jewelry.

Porotic Hyperostosis: A pathological lesion, usually associated with iron-deficiency anemia, found on the outer part of the vault of the cranium.

Postcranial Measurements: Measurements of the skeleton (see metric attributes) excluding the skull, usually used to estimate a person's stature, determine sex, etc.

Reburial: (also called reinterment) Burial of an individual after exhumation.

Relocate vs. Re-locate: Re-locate means to find again, while Relocate means to move to a new location.

Sex Determination: In the analysis of the human skeleton, determination of the sex of an individual using physical characters differing between men and women, such as the shape of the pelvis, and metric attributes.

Skeletal Inventory: An inventory of all the bones present in a single burial.

Skeletal Sample: A skeletal sample refers to a group of excavated and analyzed burials from a single location (such as a cemetery) and/or time period (such as the late 1800s/early 1900s) that may be representative of the entire group of burials in that location or time period, or the living population from which the sample was derived.

Socioeconomic: In anthropological studies, refers to the social status of an individual, based on economic factors such as occupation and income, and also factors such as family and social groups affiliation and biological affinity.

Stress vs. Stressors: In this report, stress refers to the change or response in the human body to agents or conditions, which are stressors. 
Thumb Screws: A large screw with a flattened, vertical head (often decorated) and used to attach the lid of the coffin or casket.

Trauma: An injury or wound. A fracture of one of the bones of the arm would be an example of trauma to the skeleton. 


\section{APPENDIX B: Burial Excavation and Artifact Identification Forms}




\section{BURIAL FORM I}

Prewitt and Associates, Inc.

Project Project \#

Recorder Date

Site No.

Burial No.

Grave Shaft

Soil Type

Color

\section{Casket Lid}

Wood

Wood/Glass

Metal

Indeterminate

Other

Casket Form (Plan)

Rectangular

Tapered to head

Tapered to feet

Diamond

Indeterminate

Other

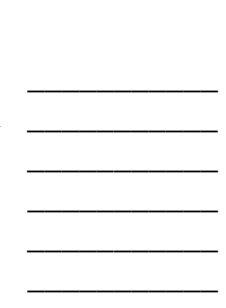

Orientation of Long Axis Orientation of Short Axis

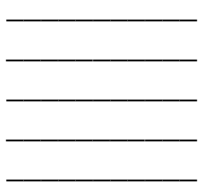

Casket Form (Cross-section)

Rectangular

Round

Square

Octagonal

Indeterminate

Other

Length of Long Axis (cm) Length of Short Axis (cm)

Description of Casket and Artifacts: 


\section{BURIAL FORM II}

Prewitt and Associates, Inc.

Project Project \#

Recorder Date

Site No.

Burial No.

Disposal

Primary

Secondary

Cremation

Burial Position

Extended

Semi-Flexed

Indeterminate

Other

Arm Location

Extended

Folded

Crossed

Left Right

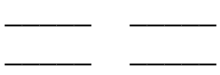

$+$

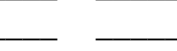

Orientation of Spine

$\circ$

$(\mathrm{E}$ or $\mathrm{W})$
Disturbance

Articulated

Disturbed

Indeterminate

Body Deposition

Supine (back)

Prone (front)

Right

Left

Indeterminate

Other

Hands

Over right Os Coxa

Over left Os Coxa

Over right shoulder

Over left shoulder

At right side

At left side

Over/near right face

Over/near left face

Indeterminate

Facing (N, S, E, W)

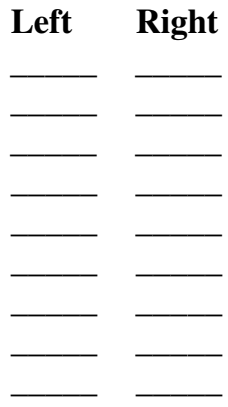

Description of Burial Position 


\section{GRAVE GOODS DATA FORM}

Prewitt and Associates, Inc.

Project

Recorder

Site No.

Burial No.

\begin{tabular}{|c|c|c|c|c|c|}
\hline \multirow[b]{2}{*}{ GRAVE GOOD } & \multicolumn{5}{|c|}{ ZONE } \\
\hline & $\mathbf{A}$ & B & $\mathbf{C}$ & D & $\mathbf{E}$ \\
\hline \multicolumn{6}{|l|}{ Personal Item } \\
\hline \multicolumn{6}{|l|}{ Glass Button } \\
\hline \multicolumn{6}{|l|}{ Bone Button } \\
\hline \multicolumn{6}{|l|}{ Shell Button } \\
\hline \multicolumn{6}{|l|}{ Porcelain Button } \\
\hline \multicolumn{6}{|l|}{ Metal Button } \\
\hline \multicolumn{6}{|l|}{ Synthetic Button } \\
\hline \multicolumn{6}{|l|}{ Stud } \\
\hline \multicolumn{6}{|l|}{ Straight Pin } \\
\hline \multicolumn{6}{|l|}{ Safety Pin } \\
\hline \multicolumn{6}{|l|}{ Snap Fastener } \\
\hline \multicolumn{6}{|l|}{ Metal Cuff Link } \\
\hline \multicolumn{6}{|l|}{ Metal Pin Jewelry } \\
\hline \multicolumn{6}{|l|}{ Metal Finger Ring } \\
\hline \multicolumn{6}{|l|}{ Metal Earring } \\
\hline \multicolumn{6}{|l|}{ Glass Bead } \\
\hline \multicolumn{6}{|l|}{ Suspender Buckle } \\
\hline \multicolumn{6}{|c|}{ Shoe Leather Fragment } \\
\hline \multicolumn{6}{|l|}{ Eyelet } \\
\hline \multicolumn{6}{|l|}{ Fabric } \\
\hline \multicolumn{6}{|l|}{ Dental Appliance } \\
\hline \multicolumn{6}{|l|}{ Comb } \\
\hline \multicolumn{6}{|l|}{ Coin } \\
\hline Other & & & & & \\
\hline
\end{tabular}




\section{MORTUARY HARDWARE DATA FORM}

Prewitt and Associates, Inc.

Project

Project \#

Recorder

Date

Site No.

Unit Coordinates (SW)

Burial No.

No. of Individuals

\begin{tabular}{|l|l|l|l|l|l|}
\hline \multicolumn{2}{|c|}{ ZONE } & \multicolumn{1}{c|}{ ( } & \multicolumn{1}{c|}{ D } & E \\
\hline MORTUARY HARDWARE & \multicolumn{1}{|c|}{ A } & & & & \\
\hline Casket Handle & & & & & \\
\hline Casket Lid Fastener & & & & & \\
\hline Receptacle Lid Fastener & & & & & \\
\hline Iron Band & & & & & \\
\hline Casket Ornament & & & & & \\
\hline Unidentified Metal & & & & & \\
\hline Coffin Wood Fragment & & & & & \\
\hline Plaque & & & & & \\
\hline Diamond Tack & & & & & \\
\hline Nail & & & & & \\
\hline Lining Tack & & & & & \\
\hline Screw & & & & & \\
\hline Corrugated Fastener & & & & & \\
\hline Viewing Window Glass & & & & & \\
\hline Decorator Tack & & & & & \\
\hline Coffin Fabric & & & & & \\
\hline Other Metal & & & & & \\
\hline Other & & & & & \\
\hline
\end{tabular}




\section{ASSOCIATED ARTIFACTS DATA FORM}

Prewitt and Associates, Inc.

Project Project \#

Recorder Date

Site No. Unit Coordinates (SW)

Burial No. No. of Individuals

\begin{tabular}{|c|c|c|c|c|c|}
\hline \multirow{2}{*}{$\begin{array}{l} \\
\text { OTHER MISCELLANEOUS } \\
\text { ARTIFACTS }\end{array}$} & \multicolumn{5}{|c|}{ ZONE } \\
\hline & $\mathbf{A}$ & B & $\mathbf{C}$ & D & $\mathbf{E}$ \\
\hline \multicolumn{6}{|l|}{ Window Glass } \\
\hline \multicolumn{6}{|l|}{ Bottle Glass } \\
\hline \multicolumn{6}{|l|}{ Ceramics } \\
\hline \multicolumn{6}{|l|}{ Pop-top Tabs } \\
\hline \multicolumn{6}{|l|}{ Metal Can } \\
\hline \multicolumn{6}{|l|}{ Metal (non-casket) } \\
\hline \multicolumn{6}{|l|}{ Other Wood Fragment } \\
\hline \multicolumn{6}{|l|}{ Porcelain } \\
\hline \multicolumn{6}{|l|}{ Brick Fragment } \\
\hline \multicolumn{6}{|l|}{ Cement/Mortar Fragment } \\
\hline Headstone Fragment & & & & & \\
\hline
\end{tabular}

\begin{tabular}{|l|l|l|l|l|l|}
\hline & \multicolumn{3}{|c|}{ ZONE } & D & D \\
\hline ORGANIC & A & B & C & \\
\hline Human Hair & & & & & \\
\hline Human Tissue & & & & & \\
\hline Animal Bone & & & & & \\
\hline Seeds & & & & & \\
\hline Nuts & & & & & \\
\hline Other & & & & \\
\hline
\end{tabular}

Pollen Sample, Grave Fill

Pollen Sample, Sacrum/Pelvis
Field Sack Number

Field Sack Number 
Appendix B: Burial Excavation and Artifact Identification Forms

\section{PLAN VIEW}

Prewitt and Associates, Inc.

Project

Project \#

Recorder

Date

Site No.

Unit Coordinates (SW)

Burial No.

No. of Individuals

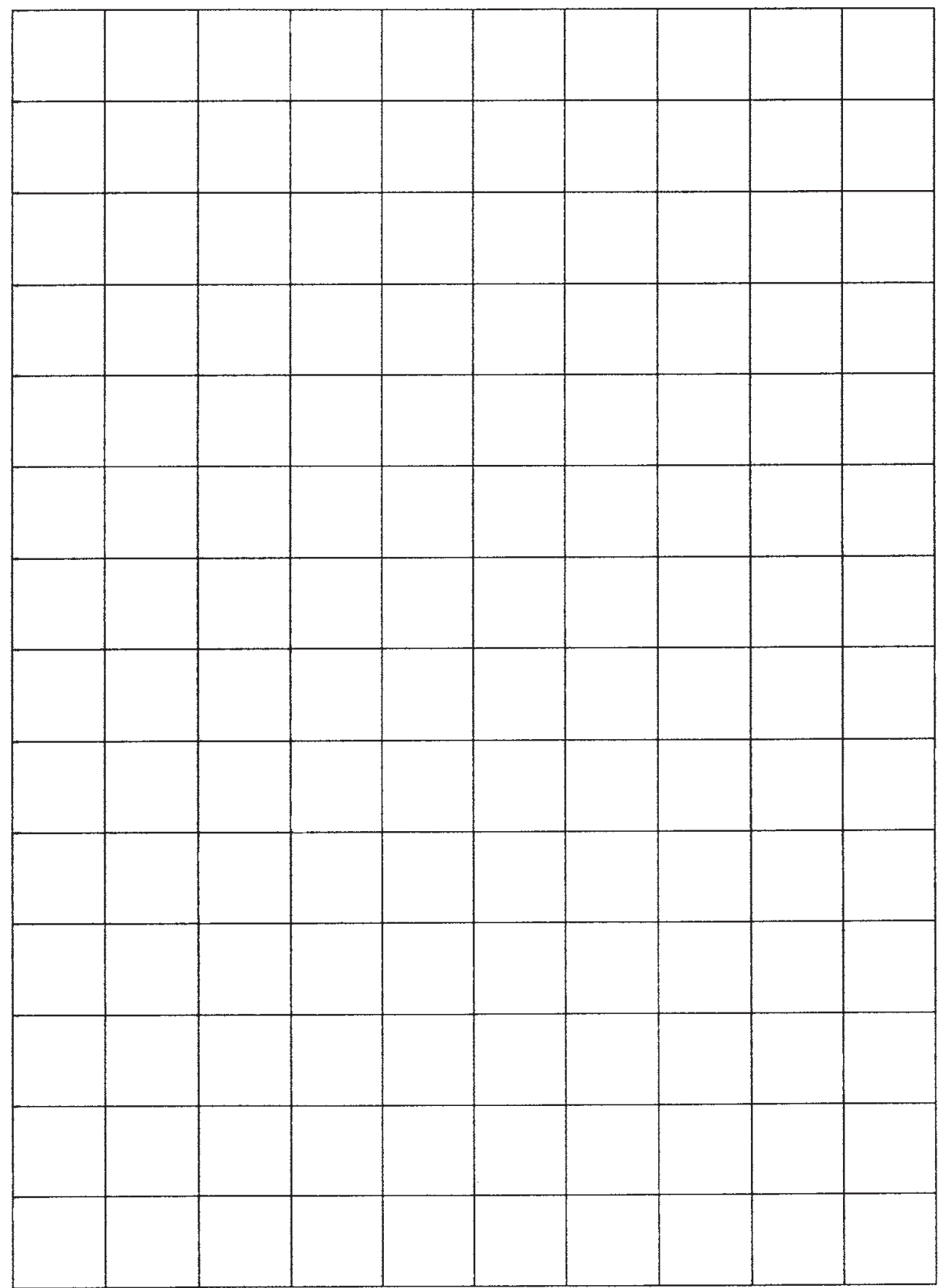

Magnetic North

\section{Centimeters}




\section{ARTIFACT IDENTIFICATION FORM}

Prewitt and Associates, Inc.

Project Project \#

Recorder Date

Site No. Unit Coordinates (SW)

Burial No. No. of Individuals

\section{Artifact Group}

Personal Item

Casket Hardware

Miscellaneous Artifact

Other/Unassociated

\section{Material Type}

Iron

Brass/Bronze/Copper

Tin

Lead

Other Metal

Glass

Ceramic

Bone

Shell

Other

\section{Artifact Type}

No. of Artifacts of this Type

Size

Maximum Length (mm)

Maximum Width (mm)

Maximum Thickness (mm)

\section{Artifact Description}

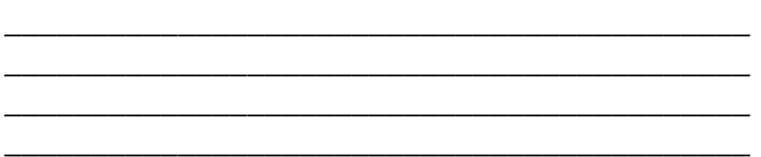

Grave Zone (circle one)

\begin{tabular}{|c|c|c|c|c|c|c|c|}
\hline Shaft Fill & $\begin{array}{c}\text { A } \\
\text { Head Area }\end{array}$ & $\begin{array}{c}\text { B } \\
\begin{array}{c}\text { Right Upper } \\
\text { Torso }\end{array}\end{array}$ & $\begin{array}{c}\text { C } \\
\text { Left Upper } \\
\text { Torso }\end{array}$ & $\begin{array}{c}\text { D } \\
\text { Right Lower } \\
\text { Torso }\end{array}$ & $\begin{array}{c}\mathbf{E} \\
\text { Left Lower } \\
\text { Torso }\end{array}$ & All Zones & Unknown \\
\hline
\end{tabular}

Location of Artifacts Within Grave

\section{Photographs \\ B\&W Roll \#} Frame \#'s
Color Roll \# Frame \#'s

Artifact Sketch (if none, indicate why) 
APPENDIX C: Osteological Analysis Forms 


\section{INVENTORY RECORDING FORM FOR COMPLETE SKELETONS}

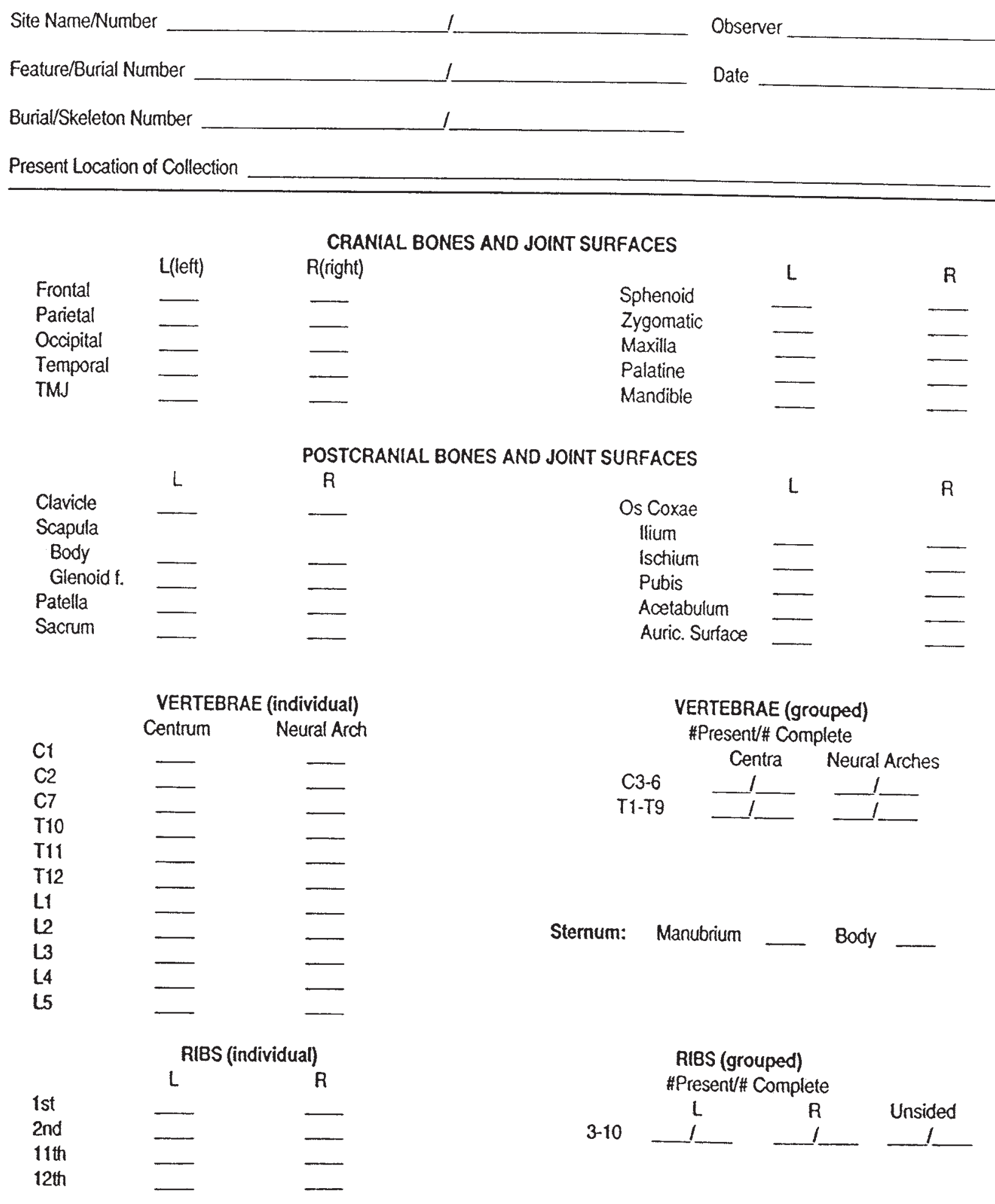




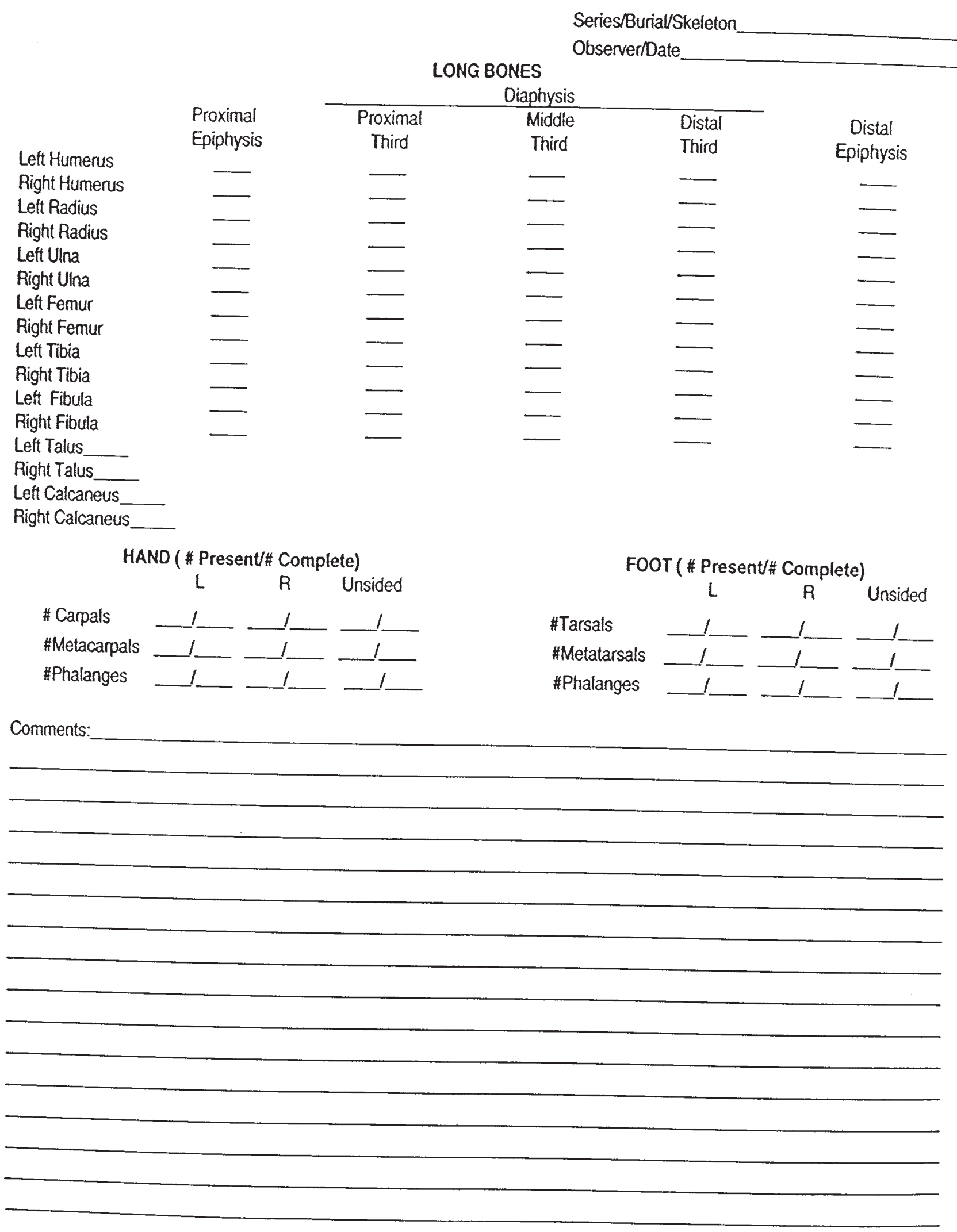




\section{ADULT SEX/AGE RECORDING FORM}

Site Name/Number
Feature/Burial Number
Burial/Skeleton Number
$\begin{aligned} & \text { Present Location of Collection } \\ & \text { Ventral Arc (1-3) } \\ & \text { Subpubic Concavity (1-3) } \\ & \text { Ischiopubic Ramus Ridge (1-3) } \\ & \text { Greater Sciatic Notch (1-5) } \\ & \text { Preauricular Sulcus (0-4) }\end{aligned}$
$\begin{aligned} & \text { Estimated Sex, Pelvis (0-5) } \\ & \text { Comments: }\end{aligned}$


Excavation and Reburial of Unmarked Historic Graves in the Pioneer Cemetery

Series/Burial/Skeleton

Observer/Date

AGE

$\begin{array}{llllll}\begin{array}{l}\text { Pubic Symphysis } \\ \text { Todd (1-10) } \\ \text { Suchey-Brooks (1-6) }\end{array} & L & R & \text { Auricular Surface (1-8) } & - & \end{array}$

Suture Closure (blank $=$ unobservable; $0=$ open; $1=$ minimal $; 2=$ significant; $3=$ complete)

External 1. Midlambdoid

Cranial 2. Lambda

Vault 3. Obelion

4. Anterior Sagittal

5. Bregma

6. Midcoronal

7. Pterion

8. Sphenofrontal

9. Inferior Sphenotemporal

10. Superior Sphenotemporal
Palate 11. Incisive

12. Anterior Median Palatine

13. Posterior Median Palatine

14. Transverse Palatine

Internal 15. Sagittal

Cranial 16. Left Lambdoid

Vault 17. Left Coronal

Estimated Age: Young Adult (20-35 years)

Middle Adult (35-50 years)

Old Adult ( $50+$ years)

Comments: 


\section{IMMATURE REMAINS RECORDING FORM: BONE UNION AND EPIPHYSEAL CLOSURE}

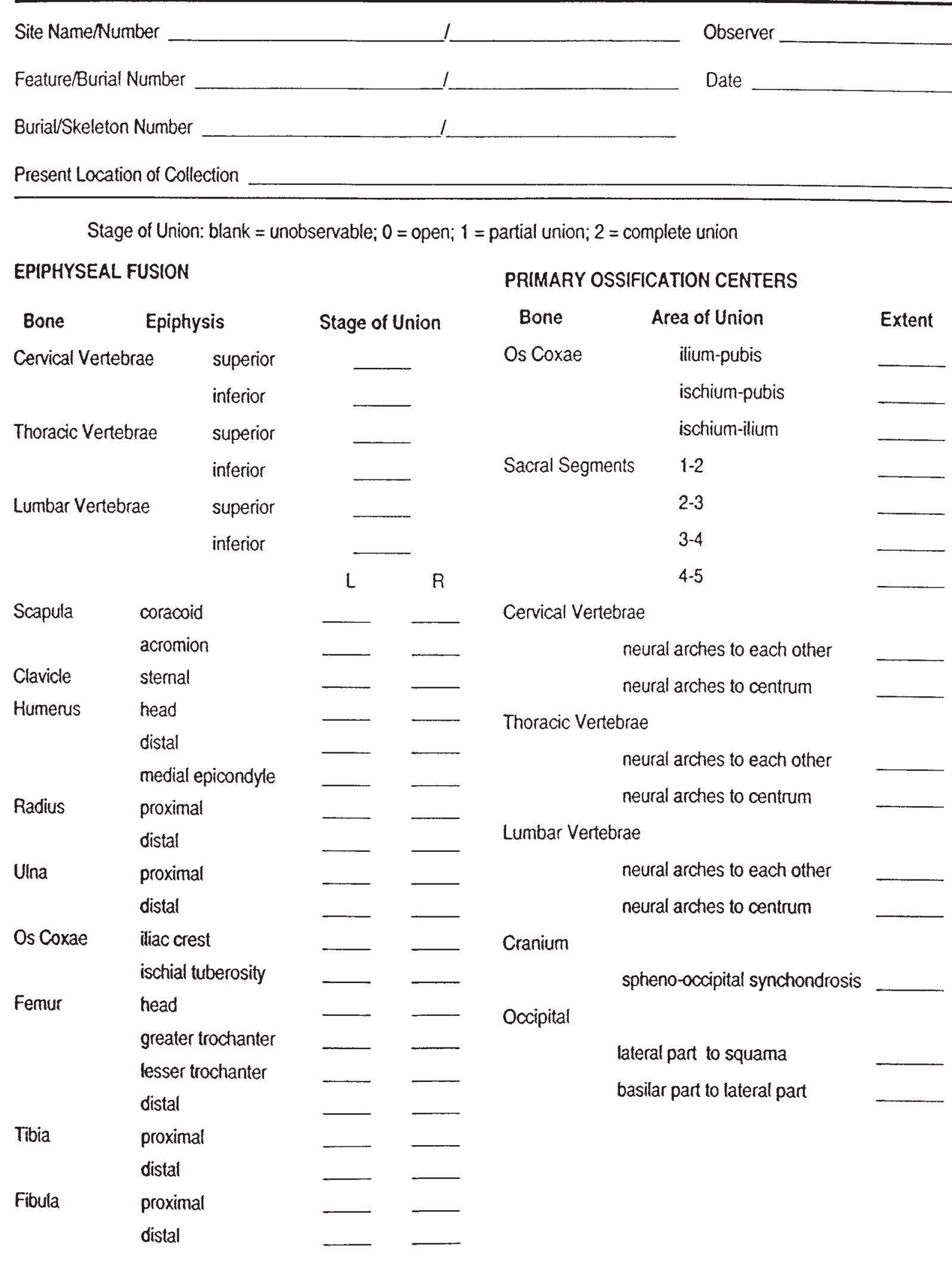


Excavation and Reburial of Unmarked Historic Graves in the Pioneer Cemetery

Series/Burial/Skeleton

Observer/Date

Estimate of chronological age based on postcranial maturation

$$
\begin{aligned}
& \text { Fetal } \\
& b-5 \\
& 5-10 \\
& 10-15 \\
& 15-20 \\
& 20+
\end{aligned}
$$

Comments: 


\section{DENTAL INVENTORY VISUAL RECORDING FORM: PERMANENT DENTITION}

Site Name/Number

Feature/Burial Number 1
Date

Observer

\section{BurialSkeleton Number}

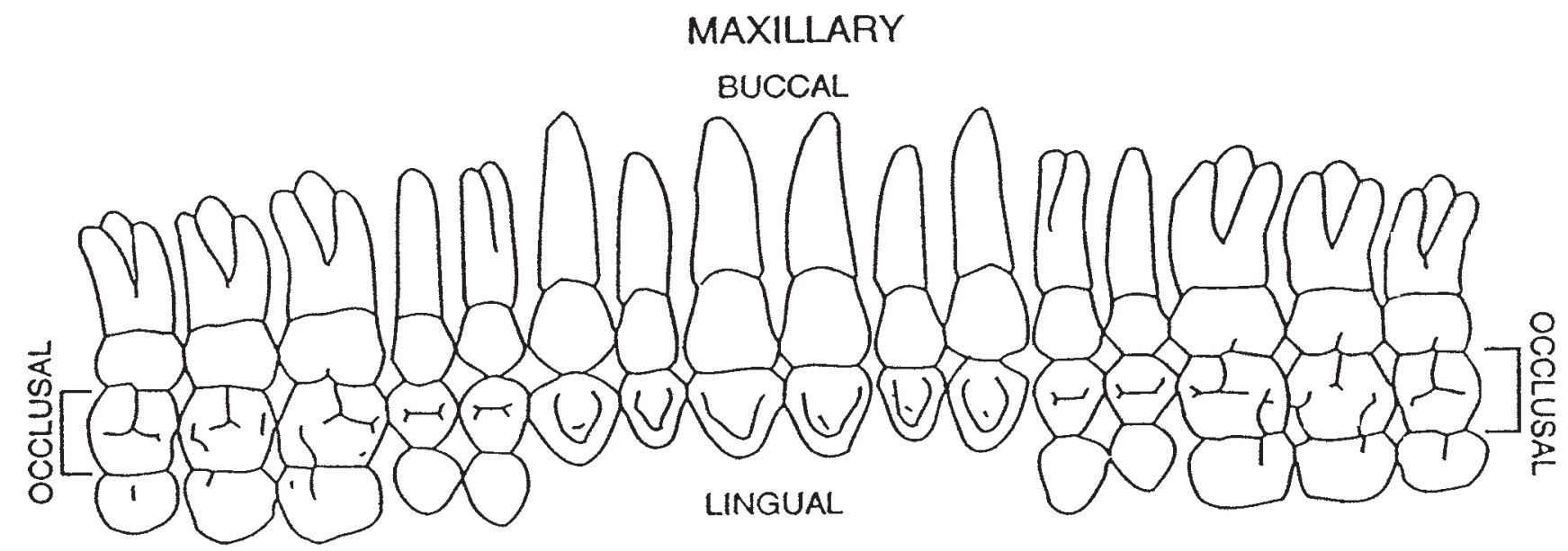

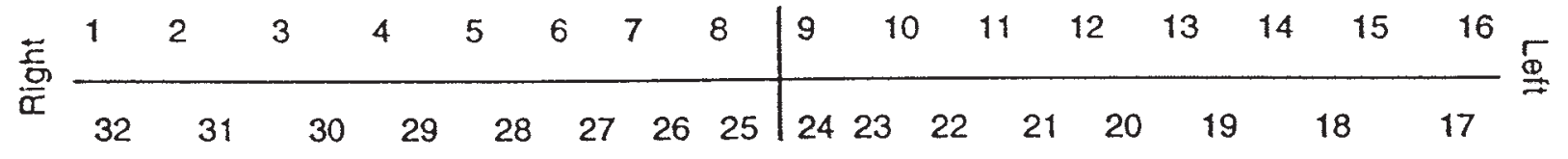

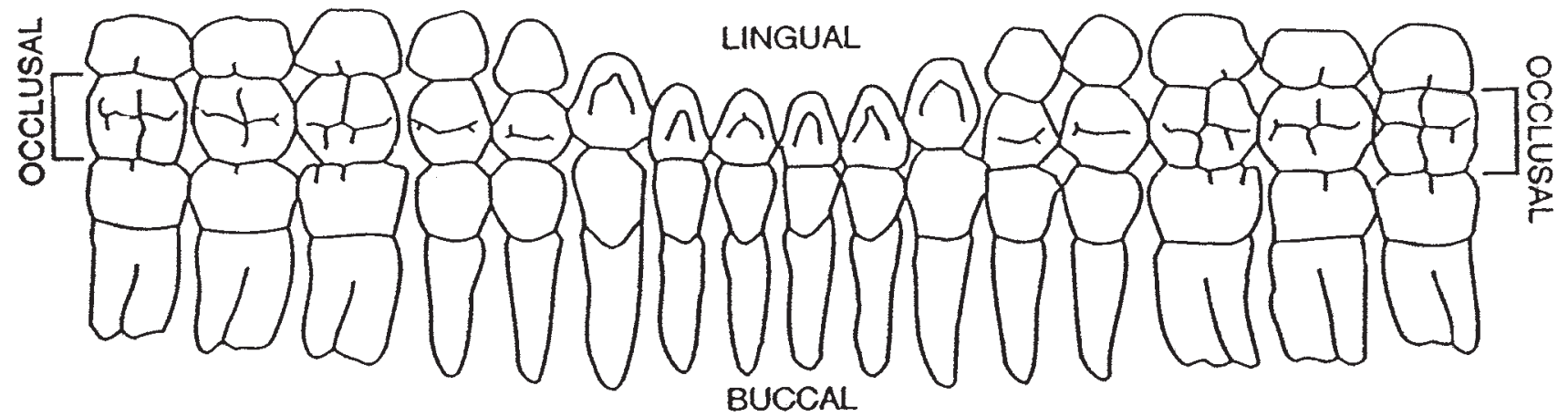

MANDIBULAR 


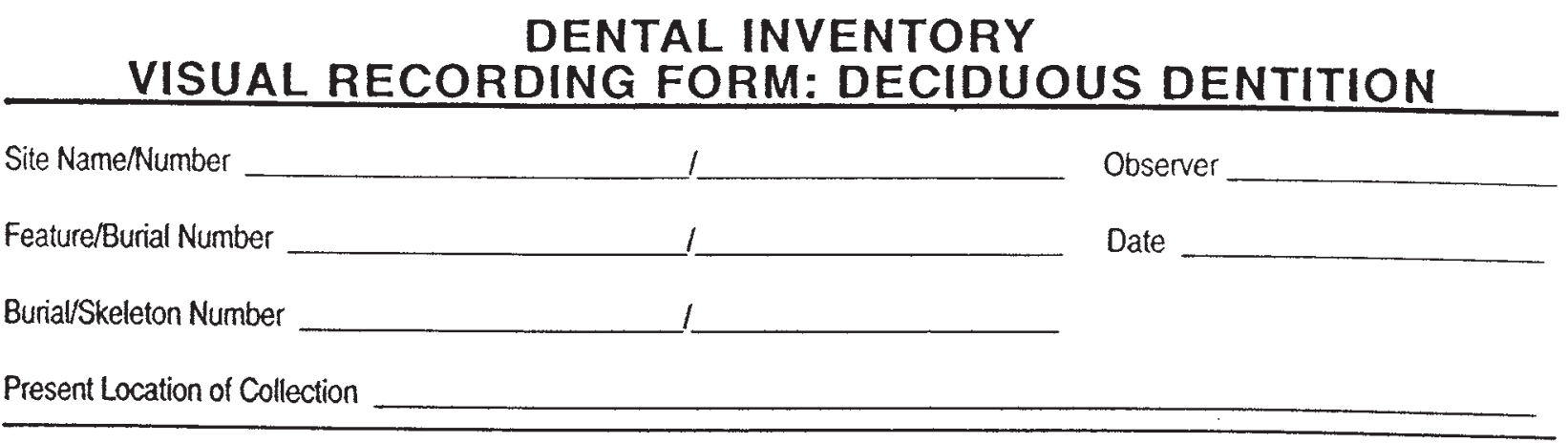

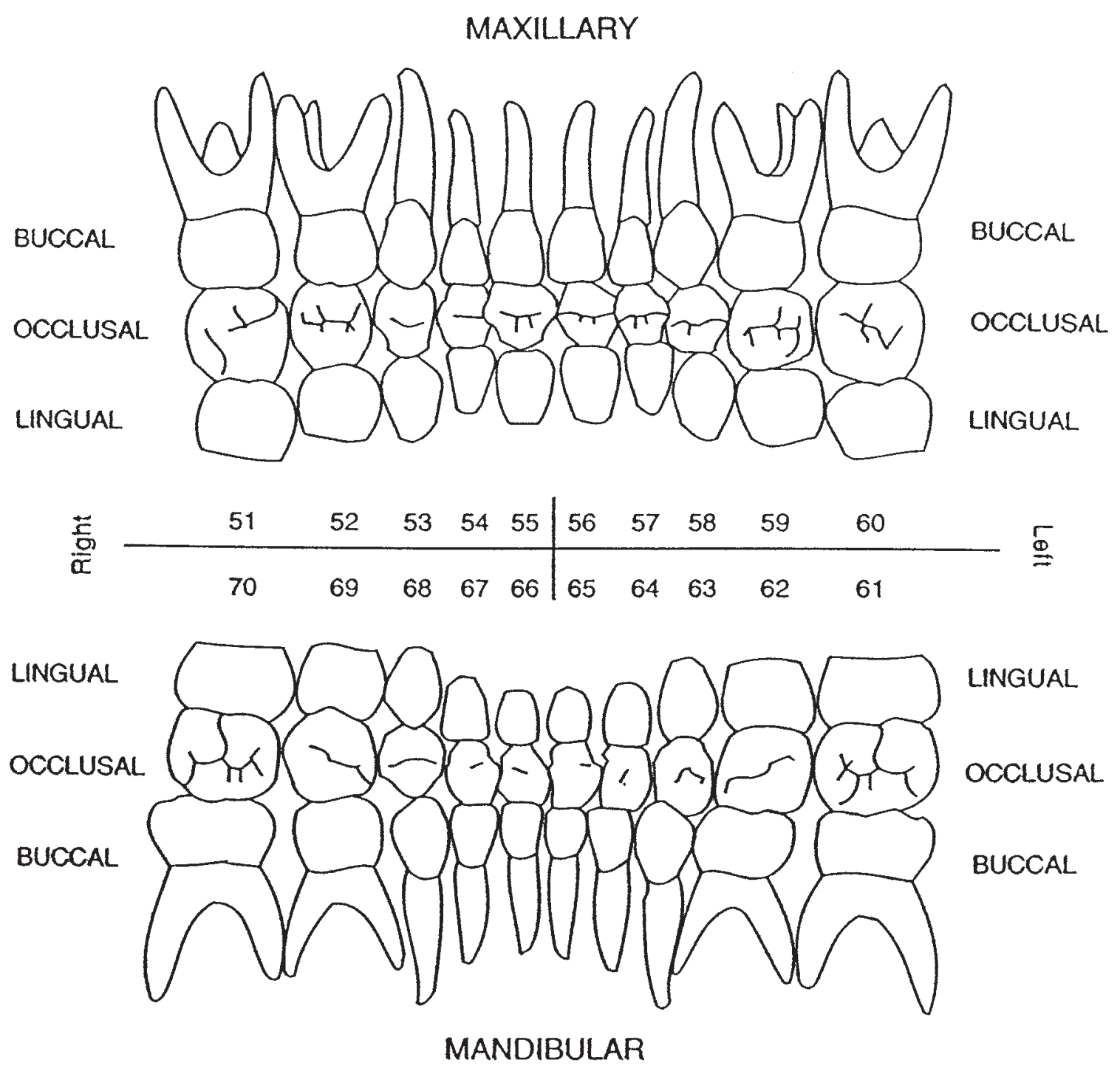




\section{DENTAL INVENTORY RECORDING FORM DEVELOPMENT, WEAR, AND PATHOLOGY: PERMANENT TEETH}

Site Name/Number

Feature/Burial Number 1

Burial/Skeleton Number

Present Location of Collection
Observer

Date

Tooth presence and development: code 1-8. For teeth entered as " 1 " (present, but not in occlusion), record stage of crown/root formation under "Development." Occlusal surface wear: use left teeth, following Smith (1984) for anterior teeth (code 1-8) and Scott (1979) for molars (code 0-10). If marked asymmetry is present, record both sides. Record each molar quadrant separate in the spaces provided ( + ) and the total for all four quadrants under "Total." Caries: code each carious lesion separately (1-7); Abscesses: code location (1-2). Calculus: code 0-3,9. Note surface affected (buccallabial or lingual).

Maxillary

$$
\text { Tooth Presence Development Wear Total }
$$

Caries

Abscess

Calculus/Affected

Right
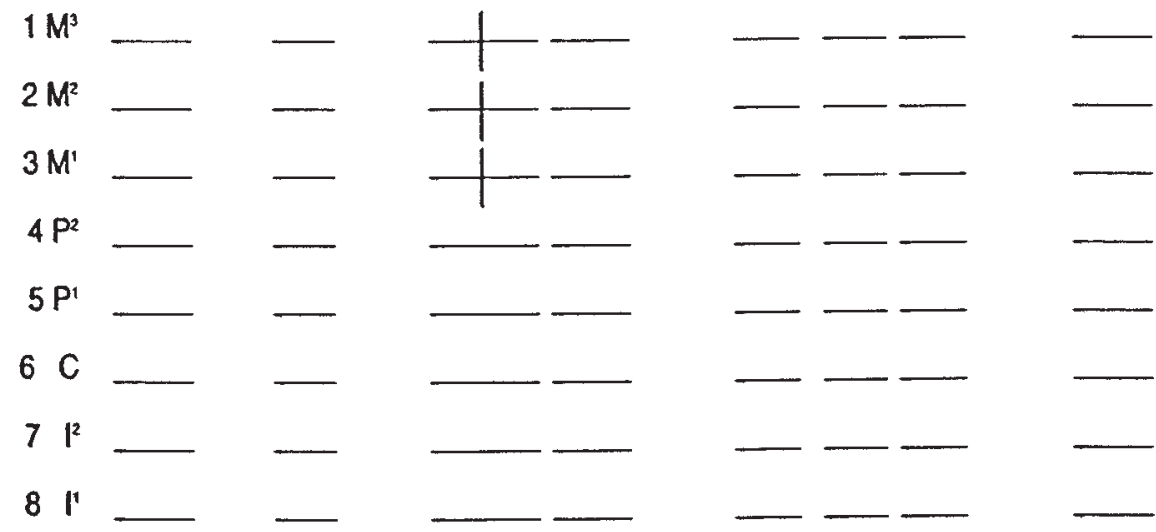

Maxillary

Left

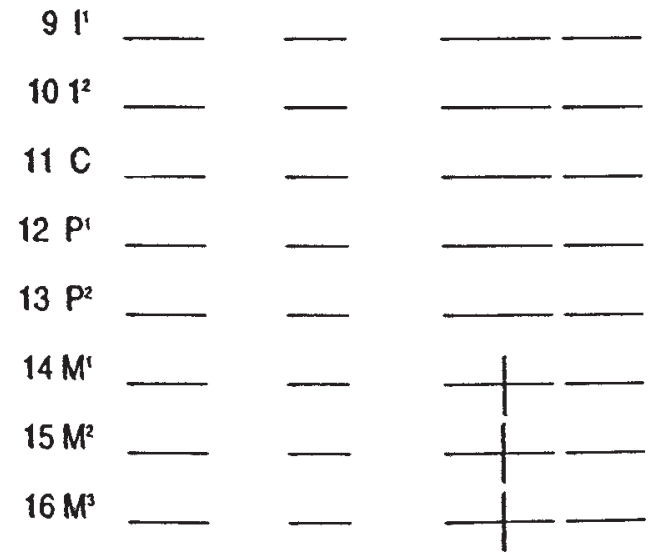


Excavation and Reburial of Unmarked Historic Graves in the Pioneer Cemetery

Series/Burial/Skeleton

ObserverDate

Mandibular

Tooth Presence Development Wear/Total Caries Abscess Calculus/Affected

Left $17 \mathrm{M}_{3}$

$18 \mathrm{M}_{2}$

$19 M_{1}$

$20 \mathrm{P}_{2}$

$21 \mathrm{P}_{1}$

$22 \mathrm{C}$

$23 k$

$24 \mathrm{~h}$

Mandibular

Right $25 \mathrm{k}$

$261_{2}$

$27 \mathrm{C}$

$28 \mathrm{P}_{1}$

$29 \mathrm{P}_{2}$

$30 \mathrm{M}_{1}$

$31 \mathrm{M}_{2}$

$32 \mathrm{M}_{3}$
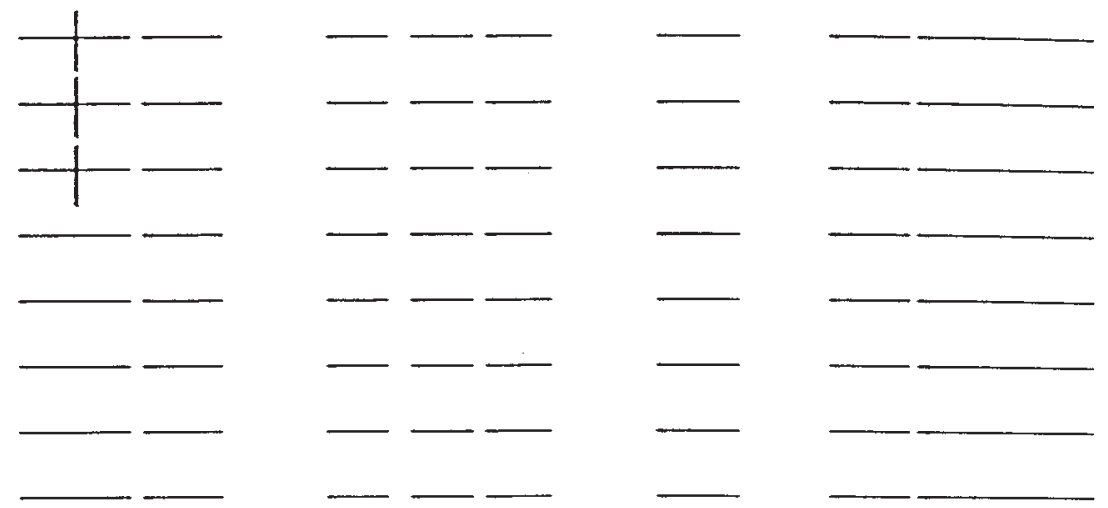

Estimated dental age (juveniles only)

Supernumerary Teeth: Position

between teeth

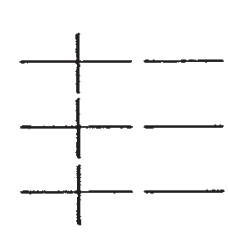

Location

$(1-4)$

Position between teeth

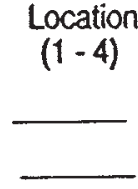

Position

Location

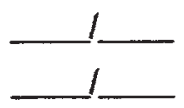
between teeth $(1-4)$

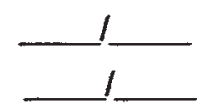

Comments: 


\title{
DENTAL INVENTORY RECORDING FORM DEVELOPMENT AND PATHOLOGY: DECIDUOUS TEETH
}

\begin{abstract}
Site NameNumber 1

Observer

Feature/Burial Number

1.

Date

Burial/Skeleton Number

1

Present Location of Collection
\end{abstract}

Tooth presence and development: code 1-8. For teeth entered as "1" (present, but not in occlusion),

record stage of crowndroot formation under "Development." Caries: code each carious lesion separately (1-

7); Abscesses: code location (1-2). Calculus: code 0-3, 9 . Note surface affected (buccal/abial or linguall).

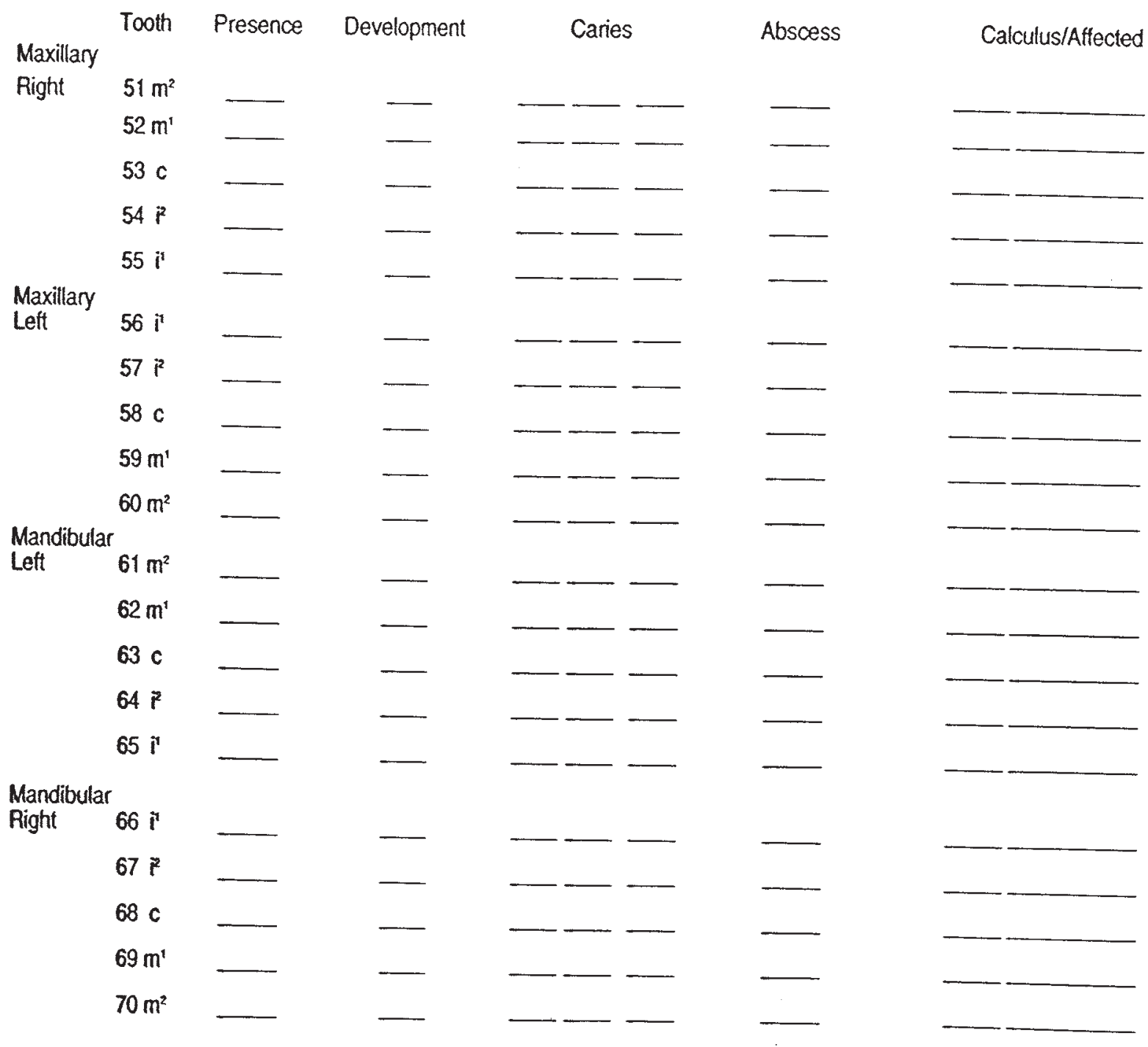


Excavation and Reburial of Unmarked Historic Graves in the Pioneer Cemetery

Series/Burial/Skeleton

Observer/Date

Estimated dental age (juveniles only)

Supernumerary Teeth: Position
between teeth $\begin{gathered}\text { Location } \\ (1-4)\end{gathered}$

$\begin{gathered}\text { Position } \\ \text { between teeth }\end{gathered}$
$\begin{gathered}\text { Location } \\ (1-4)\end{gathered}$

Comments: 


\section{ENAMEL DEFECTS (HYPOPLASIAS AND OPACITIES) RECORDING FORM: PERMANENT TEETH}

Site Name/Number 1

Feature/Burial Number

BurialSkeleton Number

Present Location of Collection
Observer

Date

Type: code 0-7 or 9; Location: measure distance from the CEJ to most occlusal portion of defect;

Color: code 1-4 for hypocalfications (type 6 or 7 ) only.

\begin{tabular}{|c|c|c|c|c|c|c|c|c|c|c|c|c|c|c|c|c|c|c|c|c|c|c|c|c|}
\hline \multicolumn{25}{|c|}{ Maxilla, Right } \\
\hline Tooth & \multicolumn{3}{|c|}{$M^{3}$} & \multicolumn{3}{|c|}{$M^{2}$} & \multicolumn{3}{|c|}{$M^{\prime}$} & \multicolumn{3}{|c|}{$P M^{2}$} & \multicolumn{3}{|c|}{$P M^{\prime}$} & \multicolumn{3}{|c|}{$\mathrm{C}$} & \multicolumn{3}{|c|}{$\dot{1}^{\dot{2}}$} & \multicolumn{3}{|c|}{1} \\
\hline Defect & 1 & 2 & 3 & 1 & 2 & 3 & 1 & 2 & 3 & 1 & 2 & 3 & 1 & 2 & 3 & 1 & 2 & 3 & 1 & 2 & 3 & 1 & 2 & 3 \\
\hline Iype & & & & & & & & & & & & & & & & & & & & & & & & \\
\hline & & & & & & & & & & & & & & & & & & & & & & & & \\
\hline Color & & & & & & & & & & & & & & & & & & & & & & & & \\
\hline
\end{tabular}

\begin{tabular}{|c|c|c|c|c|c|c|c|c|c|c|c|c|c|c|c|c|c|c|c|c|c|c|c|c|}
\hline \multicolumn{25}{|c|}{ Mandible, Left } \\
\hline Tooth & \multicolumn{3}{|c|}{$M_{3}$} & \multicolumn{3}{|c|}{$M_{2}$} & \multicolumn{3}{|c|}{$M_{1}$} & \multicolumn{3}{|c|}{$\mathrm{PM}_{2}$} & \multicolumn{3}{|c|}{$P M_{1}$} & \multicolumn{3}{|c|}{ C } & \multicolumn{3}{|c|}{$l_{2}$} & \multicolumn{3}{|c|}{$l_{1}$} \\
\hline Defect & 1 & 2 & 3 & 1 & 2 & 3 & 1 & 2 & 3 & 1 & 2 & 3 & 1 & 2 & 3 & 1 & 2 & 3 & 1 & 2 & 3 & 1 & 2 & 3 \\
\hline Type & & & & & & & & & & & & & & & & & & & & & & & & \\
\hline Location & & & & & & & & & & & & & & & & & & & & & & & & \\
\hline Color & & & & & & & & & & & & & & & & & & & & & & & & \\
\hline
\end{tabular}

\begin{tabular}{|c|c|c|c|c|c|c|c|c|c|c|c|c|c|c|c|c|c|c|c|c|c|c|c|c|}
\hline \multicolumn{25}{|c|}{ Mandible, Right } \\
\hline Tooth & \multicolumn{3}{|c|}{ I. } & \multicolumn{3}{|c|}{$b_{2}$} & \multicolumn{3}{|c|}{$\mathrm{C}$} & \multicolumn{3}{|c|}{$\mathrm{PM}_{\mathrm{r}}$} & \multicolumn{3}{|c|}{$P M_{2}$} & \multicolumn{3}{|c|}{$M_{i}$} & \multicolumn{3}{|c|}{$M_{2}$} & \multicolumn{3}{|c|}{$\mathrm{M}_{3}$} \\
\hline Defect & 1 & 2 & 3 & 1 & 2 & 3 & 1 & 2 & 3 & 1 & 2 & 3 & 1 & 2 & 3 & 1 & 2 & 3 & 1 & 2 & 3 & 1 & 2 & 3 \\
\hline Type & & & & & & & & & & & & & & & & & & & & & & & & \\
\hline Location & & & & & & & & & & & & & & & & & & & & & & & & \\
\hline Cotor & & & & & & & & & & & & & & & & & & & & & & & & \\
\hline
\end{tabular}




\section{ENAMEL DEFECTS (HYPOPLASIAS AND OPACITIES) RECORDING FORM: DECIDUOUS TEETH}

Site Name/Number

Feature/Burial Number

Burial/Skeleton Number

Present Location of Collection

Type: code $0-7$ or 9 .

Location: measure distance from the CEJ to the most ooclusal portion of defect.

Color: code 1-4 for hypocalfications (type 6 or 7 ) only.

\begin{tabular}{|c|c|c|c|c|c|c|c|c|c|c|c|c|c|c|c|}
\hline & \multicolumn{15}{|c|}{ Maxilla, Right } \\
\hline Tooth & \multicolumn{3}{|c|}{$\mathrm{m}^{2}$} & \multicolumn{3}{|c|}{$\mathbf{m}^{1}$} & \multicolumn{3}{|c|}{ c } & \multicolumn{3}{|c|}{$i^{2}$} & \multicolumn{3}{|c|}{$i^{\prime}$} \\
\hline Defect & 1 & 2 & 3 & 1 & 2 & 3 & 1 & 2 & 3 & 1 & 2 & 3 & 1 & 2 & 3 \\
\hline Type & & & & & & & & & & & & & & & \\
\hline Location & & & & & & & & & & & & & & & \\
\hline Color & & & & & & & & & & & & & & & \\
\hline
\end{tabular}

\begin{tabular}{|l|c|c|c|c|c|c|c|c|c|c|c|c|c|c|c|}
\hline Tooth & \multicolumn{10}{|c|}{$\mathrm{i}^{\prime}$} & \multicolumn{1}{c|}{ Maxilla, Left } \\
\hline Defect & 1 & 2 & 3 & 1 & 2 & 3 & 1 & 2 & 3 & 1 & 2 & 3 & 1 & 2 & 3 \\
\hline Type & & & & & & & & & & & & & & & \\
\hline Location & & & & & & & & & & & & & & & \\
\hline Color & & & & & & & & & & & & & & & \\
\hline
\end{tabular}

Mandible, Left

\begin{tabular}{|l|c|c|c|c|c|c|c|c|c|c|c|c|c|c|c|}
\hline Tooth & \multicolumn{3}{|c|}{$\mathrm{m}_{2}$} & \multicolumn{3}{|c|}{$\mathrm{m}_{\mathrm{r}}$} & \multicolumn{3}{c|}{$\mathrm{c}$} & \multicolumn{3}{c|}{$\mathrm{i}_{2}$} & \multicolumn{3}{|c|}{ i. } \\
\hline Defect & 1 & 2 & 3 & 1 & 2 & 3 & 1 & 2 & 3 & 1 & 2 & 3 & 1 & 2 & 3 \\
\hline Type & & & & & & & & & & & & & & & \\
\hline Location & & & & & & & & & & & & & & & \\
\hline Color & & & & & & & & & & & & & & & \\
\hline
\end{tabular}

Mandible, Right

\begin{tabular}{|l|l|l|l|l|l|l|l|l|l|l|l|l|l|l|l|}
\hline Tooth & \multicolumn{3}{|c|}{$\mathrm{i}_{1}$} & \multicolumn{3}{|c|}{$\mathrm{i}_{2}$} & \multicolumn{3}{c|}{$\mathrm{c}$} & \multicolumn{3}{c|}{$\mathrm{m}_{1}$} & \multicolumn{3}{|c|}{$\mathrm{m}_{2}$} \\
\hline Defect & 1 & 2 & 3 & 1 & 2 & 3 & 1 & 2 & 3 & 1 & 2 & 3 & 1 & 2 & 3 \\
\hline Type & & & & & & & & & & & & & & & \\
\hline Location & & & & & & & & & & & & & & & \\
\hline Color & & & & & & & & & & & & & & & \\
\hline
\end{tabular}




\section{PREMORTEM DENTAL MODIFICATIONS RECORDING FORM}

Site Name/Number

Feature/Burial Number

Burial/Skeleton Number

Present Location of Collection

Type of Modification:

1. Aesthetic modification: filing

2. Aesthetic modification: drilling

3. Dental restorations and appliances

4. Dental wear associated with artifact use or production

5. Tooth ablation
Observer

Date

Comments: 
Excavation and Reburial of Unmarked Historic Graves in the Pioneer Cemetery

Series/Burial/Skeleton

Observer/Date 


\section{CRANIAL AND POSTCRANIAL MEASUREMENT RECORDING FORM: ADULT REMAINS}

Site Name/Number 1

Feature/Burial Number

BurialSkeleton Number

Present Location of Collection
Observer

Date

Record all measurements to the nearest millimeter; in the case of bilateral measurements, take measurement on the left side. If right side is substituted, place an (R) next to the the measurement. If bones are fragmented, measurements should not be taken, but dimensions should be estimated for minor erosion or reconstruction; identify these with an asterick ${ }^{\text {k*n }}$

\section{Cranial Measurements}

1. Maximum Cranial Length:

2. Maximum Cranial Breadth:

3. Bizygomatic Diameter:

4. Basion-Bregma Height:

5. Cranial Base Length:

6. Basion-Prosthion Length:

7. Maxillo-Alveolar Breadth:

8. Maxillo-Alveolar Length:

9. Biauricular Breadth:

10. Upper Facial Height:

11. Minimum Frontal Breadth:

12. Upper Facial Breadth:

13. Nasal Height:

14. Nasal Breadth:

15. Orbital Breadth:

16. Orbital Height:

17. Biorbital Breadth:
18. Interorbital Breadth:

19. Frontal Chord:

20. Parietal Chord:

21. Occipital Chord:

22. Foramen Magnum Length:

23. Foramen Magnum Breadth:

24. Mastoid Length:

25. Chin Height

26. Height of the Mandibular Body:

27. Breadth of the Mandibular Body:

28. Bigonial Width:

29. Bicondylar Breadth:

30. Minimum Ramus Breadth:

31. Maximum Ramus Breadth:

32. Maximum Ramus Height:

33. Mandibular Length:

34. Mandibular Angle: 


\section{Series/Burial/Skeleton}

ObserverDate

Record all measurements to the nearest millimeter; in the case of bitateral measurements, take measurement on the left side. If right side is substituted, place an $(\mathrm{R})$ next to the the measurement. If bones are fragmented, measurements should not be taken, but dimensions should be estimated for minor erosion or reconstruction; identify these with an asterick ${ }^{\star * n}$

\section{Postcranial Measurements}

35. Clavicle: Maximum Length:

36. Clavicle: Ant.-Post. Diameter at Midshaft:

37. Clavicle: Sup.-Inf. Diameter at Midshaft:

38. Scapula: Height:

39. Scapula: Breadth:

40. Humerus: Maximum Length:

41. Humerus: Epicondylar Breadth:

42. Humerus: Vertical Diameter of Head:

43. Humerus: Maximum Diameter at Midshaft:

44. Humerus: Minimum Diameter at Midshaft:

45. Radius: Maximum Length:

46. Radius: Anterior-Posterior Diameter at Midshaft :

47. Radius: Medial-Lateral Diameter at Midshaft:

48. Uina: Maximum Length:

49. Ulna: Anterior-Posterior Diameter:

50. Ulna: Medial-Lateral Diameter:

51. Unna: Physiological Length:

52. Ulna: Minimum Circumference:

53. Sacrum: Anterior Length:

54. Sacrum: Anterior Superior Breadth:

55. Sacrum: Max. Transverse Diameter of Base:

56. Os Coxae: Height:
57. Os Coxae: lliac Breadth:

58. Os Coxae: Pubis Length:

59. Os Coxae: Ischium Length:

60. Femur: Maximum Length:

61. Femur: Bicondylar Length:

62. Femur: Epicondylar Breadth:

63. Femur: Maximum Diameter of the Femur Head:

64. Femur: Ant.-Post. Subtrochanteric Diameter:

65. Femur: Medial-Lateral Subtrochanteric Diameter:

66. Femur: Anterior-Posterior Midshaft Diameter:

67. Femur: Medial-Lateral Midshaft Diameter:

68. Femur: Midshaft Circumference:

69. Tibia: Length:

70. Tibia: Maximum Proximal Epiphyseal Breadth:

71. Tibia: Maximum Distal Epiphyseal Breadth:

72. Tibia: Max. Diameter at the Nutrient Foramen:

73. Tibia: Med.Lat. Diameter at Nutrient Foramen:

74. Tibia: Circumference at the Nutrient Foramen:

75. Fibula: Maximum Length:

76. Fibula: Maximum Diameter at Midshaft:

77. Calcaneus: Maximum Length:

78. Calcaneus: Middle Breadth: 


\section{PRIMARY NONMETRIC TRAITS RECORDING FORM}

Site Name/Number

Feature/Burial Number

Burial/Skeleton Number

Present Location of Collection
Observer

Date
1. Metopic Suture:

$0=$ absent

$1=$ partial

$2=$ complete

$9=$ unobservable

2. Supraorbital Structures

a. Supraorbital notch:

$0=$ absent

$1=$ present $_{1}<1 / 2$ occluded by spicules

$2=$ present $>1 / 2$ occluded by spicules

$3=$ present, degree of coclusion unknown

$4=$ multiple notches

$9=$ unobservable

b. Supraorbital foramen:

$0=$ absent

$1=$ present

2 = multiple foramina

$9=$ unobservable

3. Infraorbital Suture:

$$
\begin{aligned}
& 0=\text { absent } \\
& 1=\text { partial } \\
& 2=\text { complete } \\
& 9=\text { unobservable }
\end{aligned}
$$

4. Muttiple Intraorbital Foramina:

$$
\begin{aligned}
& 0=\text { absent } \\
& 1=\text { intemal division only } \\
& 2=\text { two distinct foramina } \\
& 3=\text { more than two distinct foramina } \\
& 9=\text { unobservable }
\end{aligned}
$$

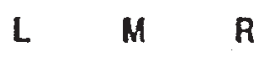

\section{Zygomatico-facial Foramina:}

$$
\begin{aligned}
& 0=\text { absent } \\
& 1=1 \text { large } \\
& 2=1 \text { large plus smaller } \mathrm{t} . \\
& 3=2 \text { large } \\
& 4=2 \text { large plus smaller } \mathrm{f} . \\
& 5=1 \text { small } \\
& 6=\text { multiple small } \\
& 9=\text { unobservable }
\end{aligned}
$$

\section{Parietal Foramen:}

$$
\begin{aligned}
& 0=\text { absent } \\
& 1=\text { present, on parietal } \\
& 2=\text { present, sutural } \\
& 9=\text { unobservable }
\end{aligned}
$$

\section{Sutural Bones}

$0=$ absent

$1=$ present

$9=$ unobservable

a. epipteric bone:

b. coronal ossicle:

c. bregmatic bone:

d. sagittal ossicle:

e. apical bone:

f. lambdoid ossicle:

g. asterionic bone:

h ossicle in occipitomastoid suture:

i. parietal notch bone:

8. Inca Bone

$$
\begin{aligned}
& 0=\text { absent } \\
& 1=\text { complete }, \text { single bone } \\
& 2=\text { bipartite } \\
& 3=\text { tripartite } \\
& 4=\text { partial } \\
& 9=\text { unobservable }
\end{aligned}
$$

\section{Condylar Canal:}

$0=$ not patent

$1=$ patent

$9=$ unobservable

10. Divided Hypoglossal Canal:

$$
0=a b s e n t
$$

1 = partial, internal surface

$2=$ partial, within canal

$3=$ complete, intemal surface

$4=$ complete, within canal

$9=$ unobservable

11. Flexure of Superior Sagittal Sulcus

$$
\begin{aligned}
& 1=\text { Right } \\
& 2=\text { Left } \\
& 3=\text { Bifurcate } \\
& 9=\text { Unobservable }
\end{aligned}
$$

12. Foramen Ovale Incomplete:

$$
\begin{aligned}
& 0=\text { absent } \\
& 1=\text { partial formation } \\
& 2=\text { no definition of foramen } \\
& 9=\text { unobservable }
\end{aligned}
$$


Series/Burial/Skeleton

Observer/Date

L M R

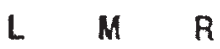

13. Foramen Spinosum Incomplete:

$$
\begin{aligned}
& 0=\text { absent } \\
& 1=\text { partial formation } \\
& 2=\text { no definition of foramen } \\
& 9=\text { unobservable }
\end{aligned}
$$

20. Mandibular Torus:

$$
\begin{aligned}
& 0=\text { absent } \\
& 1=\text { trace (can palpate but not see) } \\
& 2=\text { moderate: elevation between } 2-5 \mathrm{~mm} . \\
& 3=\text { marked: elevation greater than } 5 \mathrm{~mm} . \\
& 9=\text { unobservable }
\end{aligned}
$$

14. Pterygo-spinous Bridge:

$$
\begin{aligned}
& 0=\text { absent } \\
& 1=\text { trace (spicule only) } \\
& 2=\text { partial bridge } \\
& 3=\text { complete bridge } \\
& 9=\text { unobservable }
\end{aligned}
$$

15. Pterygo-alar Bridge:

$$
\begin{aligned}
& 0=\text { absent } \\
& 1=\text { trace (spicule only) } \\
& 2=\text { partial bridge } \\
& 3=\text { complete bridge } \\
& 9=\text { unobservable }
\end{aligned}
$$

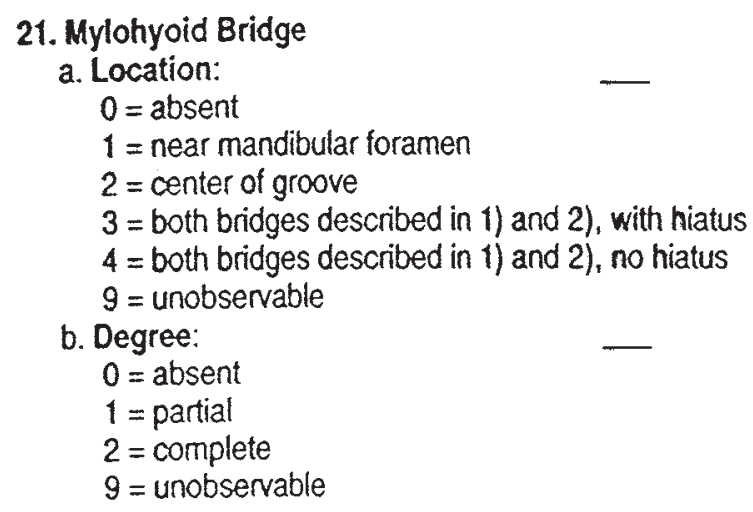

16. Tympanic Dihiscence:

$0=\mathrm{absent}$

$1=$ foramen only

2 = full defect present

$9=$ unobservable

17. Auditory Exostosis:

$$
\begin{aligned}
& 0=\text { absent } \\
& 1=<1 / 3 \text { canal occluded } \\
& 2=1 / 3-2 / 3 \text { canal occluded } \\
& 3=>2 / 3 \text { canal occluded } \\
& 9=\text { unobservable }
\end{aligned}
$$

\section{Mastoid Foramen}

a. Location:

$0=a b s e n t$

$1=$ temporal

$2=$ sutural

$3=$ occipital

$4=$ both sutural and temporal $5=$ both occipital and temporal $9=$ unobservable

b. Number:

$$
\begin{aligned}
& 0=\text { absent } \\
& 1=1 \\
& 2=2 \\
& 3=\text { more than } 2 \\
& 9=\text { unobservable }
\end{aligned}
$$

19. Mental Foramen:

$$
\begin{aligned}
& 0=\text { absent } \\
& 1=1 \\
& 2=2 \\
& 3=>2 \\
& 9=\text { unobservable }
\end{aligned}
$$

\section{Atlas Bridging}

a. Lateral Bridging:

$$
\begin{aligned}
& 0=\text { absent } \\
& 1=\text { partial } \\
& 2=\text { complete } \\
& 9=\text { unobservable } \\
& \text { b. Posterior Bridging: } \\
& 0=\text { absent } \\
& 1=\text { partial } \\
& 2=\text { complete } \\
& 9=\text { unobservable }
\end{aligned}
$$

23. Accessory Transverse Foramina:

$$
\begin{aligned}
\text {-in } 7 \text { th Cervical Vertebra } \\
0=\text { absent } \\
1=\text { partial } \\
2=\text { complete } \\
9=\text { unobservable }
\end{aligned}
$$

\section{Septal Aperture:}

$0=a b s e n t$

1 = small foramen (pinhole) only

$2=$ true perforation

$9=$ unobservable

R 
PALEOPATHOLOGY RECORDING FORM I SHAPE, SIZE, BONE LOSS, FORMATION, FRACTURES, AND POROTIC HYPEROSTOSIS

Site Name/Number

Feature/Burial Number

Burial/Skeleton Number

Present Location of Collection
Observer

Date

\subsection{SHAPE}

Bone___
Side__
Bone___
Side__
Obs1___
Obs2

Bone
Side__
Bone___
Side___
Obs1__
Obs2

Bone
Side_-
Bone_-
Side_-
Obs1
Obs2

Bone
Side_-
Bone
Side
Obs1
Obs2

Bone
Side
Bone
Side
Obs1
Obs2

Bone
Side_-
Bone
Side_-
Obs1
Obs2

\subsection{SIZE}

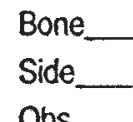

\subsection{BONE LOSS}

Bone
Side-
Section
Aspect
Obs1
Obs2
Obs3
Obs4
Obs5
Obs6
Obs7
Obs8

Bone
Side
Obs

Bone

Side

Section

Aspect

Obs1

Obs2

Obs3

Obs4

Obs5

Obs6

Obs7

Obs8
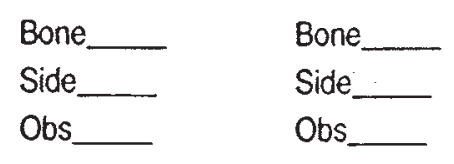

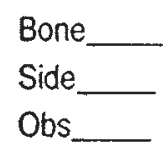

Bone
Side
Obs

\subsection{FORMATION}

\begin{tabular}{|c|c|c|c|c|c|}
\hline Bone & Bone_ & Bone & Bone & Bone & Bone \\
\hline Side & Side_ & Side_ & Side_ & Side & Side \\
\hline Section & Section & Section & Section & Section & Section \\
\hline Aspect & Aspect & Aspect & Aspect & Aspect & Aspect \\
\hline Obs1_ & Obs1 & Obs1 & Obs1_ & Obs1_. & Oos 1 \\
\hline Obs2 & Obs2 & Obs2 & Obs2 & Obs2. & Obs2_ \\
\hline Obs3 & Obs3 & Obs3 & Obs3 & Obs3 & Obs3 \\
\hline Obs4 & Obs4 & Obs4_ & Obs4 & Obs4 & Obs4 \\
\hline Obs5 & Obs5 & Obs5 & Obs5 & Obs5 & Oos5 \\
\hline Obs6_ & Obs6 & Obs6 & Obs6 & Obs6 & Obs6 \\
\hline
\end{tabular}


Series/Burial/Skeleton

ObserverOate

\subsection{FRACTURES}

\begin{tabular}{|c|c|c|c|c|c|}
\hline Bone & Bone & Bone_ & Bone_ & Bone & Bone \\
\hline Side_ & Side & Side_ & Side_ & Side & Side \\
\hline Section & Section & Section & Section & Section & Section \\
\hline Obsi_ & Obs1 & Obs1_ & Obsi_ & Obs1_ & Obst \\
\hline Obs2 & Obs2 & Obs2 & Obs2 & Obs2 & Obs2 \\
\hline Obs3 & Obs3 & Obs3 & Obs3 & Obs3 & Obs3 \\
\hline Obs4 & Obs4 & Obs4 & Obs4 & Obs4 & Obs4 \\
\hline Obs5 & Obs5 & Obs5 & Obs5 & Obs5 & Obs5 \\
\hline Obs6 & Obs6_ & Obs6_ & Obs6 & Obs6 & Obs6 \\
\hline Obs7 & Obs7 & Obs7 & Obs7_ & Obs7 & Obs7_ \\
\hline Obs8 & Obs8 & Obs8 & Obs8 & Obs8 & Obs8 \\
\hline Obs9 & Obs9 & Obs9 & Obs9_ & Obs9 & Obs9 \\
\hline Obs10 & Obs10 & Obs10 & Obsio & Obs10 & Obs10 \\
\hline Obsi1 & Obs11 & Obs11 & Obs11 & Obs11_ & Obsi1 \\
\hline
\end{tabular}

\subsection{POROTIC HYPEROSTOSIS}

\begin{tabular}{|c|c|c|c|c|c|}
\hline Bone & Bone & Bone_ & Bone & Bone & Bone \\
\hline Side_ & Side & Side & Side_ & Side & Side_ \\
\hline Obs1 & Obs1 & Obs1_ & Obs1 & Obs1 & Obs1 \\
\hline Obs2 & Obs2 & Obs2 & Obs2 & Obs2 & Obs2 \\
\hline Obs3 & Obs3 & Obs3 & Obs3 & Obs3 & Ohas \\
\hline
\end{tabular}

Comments: 


\section{PALEOPATHOLOGY RECORDING FORM II VERTEBRAL PATHOLOGY, ARTHRITIS, AND MISCELLANEOUS}

Site Name/Number

Feature/Burial Number

Burial/Skeleton Number

Present Location of Collection
Observer

Date

\subsection{VERTEBRAL PATHOLOGY}

\begin{tabular}{|c|c|c|c|c|c|}
\hline Bone & Bone & Bone & Bone & Bone & Bone \\
\hline Side_ & Side & Side & Side & Side & Side \\
\hline Aspect & Aspect & Aspect & Aspect & Aspect & Aspect \\
\hline Bone & Bone & Bone & Bone & Bone & Bone \\
\hline Side & Side & Side & Side & Side & Side \\
\hline Aspect & Aspect & Aspect & Aspect & Aspect & Aspect \\
\hline Obs1 & Obs1 & Obs1 & Obs 1 & Obs1 & Obs1 \\
\hline Obs2 & Obs2 & Obs2 & Obs2 & Obs2 & Obs 2 \\
\hline Obs3 & Obs3 & Obs3 & Obs3 & Obs3 & Obs 3 \\
\hline
\end{tabular}

\subsection{ARTHRITIS}

\begin{tabular}{|c|c|}
\hline Bone & Bone \\
\hline Side & Side \\
\hline Section & Section \\
\hline Aspect & Aspect \\
\hline Bone & Bone \\
\hline Side & Side \\
\hline Section & Section \\
\hline Aspect & Aspect \\
\hline Obs1. & Obs1_ \\
\hline Obs2. & Obs2 \\
\hline Obs3. & Ots3 \\
\hline Obs4 & Obs4 \\
\hline Obs5 & Obs5 \\
\hline Obs6 & Obs6 \\
\hline Obs7 & Obs7 \\
\hline Obs8 & Ots8 \\
\hline Obs9 & Obs9 \\
\hline
\end{tabular}

\section{MISCELLANEOUS}

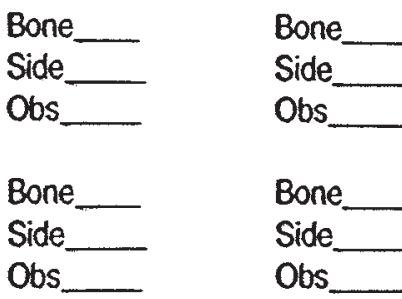

Bone
Side
Section
Aspect
Bone
Side
Section
Aspect
Obs1
Obs2
Obs3
Obs4
Obs5
Obs6
Obs7
Obs8
Obs9

Bone
Side
Section
Aspect
Bone
Side
Section
Aspect
Obs1
Obs2
Obs3
Obs4
Obs5
Obs6
Obs7
Obs8
Obs9

Bone
Side
Section/
Aspect
Bone
Side
Section/
Aspect
Obs1
Obs2
Obs3
Obs4
Obs5
Obs6
Obs7
Obs8
Obs9

Bone

Side Section Aspect Bone Side Section Aspect

Obs1

Obs2

Obs3

Obs4 Obs5

Obs6

Obs7 Obs8 Obs9

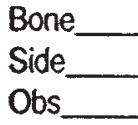

Bone
Side
Obs
Bone
Side
Obs

Bone
Side
Obs
Bone
Side
Obs

Bone Side Obs

Bone
Side
Obs


Excavation and Reburial of Unmarked Historic Graves in the Pioneer Cemetery

Series/Burial/Skeleton

Observer/Date

COMMENTS 

APPENDIX D: Osteological Data 
Table D.1. Skeletal inventory

\begin{tabular}{|c|c|c|c|}
\hline Element & Burial 1 & Burial 3 & Burial 4 \\
\hline L frontal & 1 & 2 & \\
\hline $\mathrm{R}$ frontal & 1 & 1 & \\
\hline L parietal & 1 & 1 & \\
\hline $\mathrm{R}$ parietal & 2 & 1 & \\
\hline L occipital & 1 & 1 & \\
\hline $\mathrm{R}$ occipital & 1 & 1 & \\
\hline L temporal & 1 & 1 & 2 \\
\hline $\mathrm{R}$ temporal & 1 & 1 & 2 \\
\hline L TMJ & 1 & 3 & \\
\hline R TMJ & 1 & 1 & \\
\hline L sphenoid & 2 & 2 & \\
\hline R sphenoid & 2 & 2 & \\
\hline L zygomatic & 1 & 1 & \\
\hline $\mathrm{R}$ zygomatic & 1 & 1 & \\
\hline L maxilla & 1 & 2 & \\
\hline $\mathrm{R}$ maxilla & 1 & 1 & \\
\hline \multicolumn{4}{|l|}{ L palatine } \\
\hline \multicolumn{4}{|l|}{$\mathrm{R}$ palatine } \\
\hline L mandible & 1 & 1 & \\
\hline $\mathrm{R}$ mandible & 1 & 1 & \\
\hline L clavicle & 1 & 1 & \\
\hline $\mathrm{R}$ clavicle & 1 & & \\
\hline L scap. body & 3 & 2 & \\
\hline $\mathrm{R}$ scap. body & 3 & 2 & \\
\hline L scap. glenoid & 1 & 1 & \\
\hline R scap. glenoid & 1 & 1 & \\
\hline L patella & 1 & 1 & \\
\hline $\mathrm{R}$ patella & 1 & 1 & \\
\hline L sacrum & 2 & & \\
\hline $\mathrm{R}$ sacrum & 2 & & \\
\hline L ilium & 2 & 3 & \\
\hline $\mathrm{R}$ ilium & 2 & 2 & \\
\hline L ischium & 1 & & \\
\hline $\mathrm{R}$ ischium & 1 & & \\
\hline \multicolumn{4}{|l|}{$\mathrm{L}$ pubis } \\
\hline $\mathrm{R}$ pubis & 1 & & \\
\hline $\mathrm{L}$ acetabulum & 2 & 1 & \\
\hline $\mathrm{R}$ acetabulum & 2 & 1 & \\
\hline L aur. surf. & 3 & 2 & \\
\hline $\mathrm{R}$ aur. surf. & 3 & 2 & \\
\hline C1 centrum & 1 & 1 & \\
\hline C1 neural arch & 1 & 3 & \\
\hline C2 centrum & 1 & 1 & \\
\hline C2 neural arch & 1 & & \\
\hline C3-6 centrum* & $4 / 4$ & $2 / 0$ & \\
\hline C3-6 neural arch* & $3 / 0$ & & \\
\hline C7 centrum & 1 & 1 & \\
\hline C7 neural arch & 1 & & \\
\hline T1-T9 centrum* & $9 / 6$ & & \\
\hline T1-T9 neural arch* & $9 / 9$ & $6 / 0$ & \\
\hline T10 centrum & 1 & & \\
\hline
\end{tabular}


Table D.1, continued

\begin{tabular}{|c|c|c|c|}
\hline Element & Burial 1 & Burial 3 & Burial 4 \\
\hline T10 neural arch & 1 & & \\
\hline T11 centrum & 1 & & \\
\hline T11 neural arch & 1 & & \\
\hline T12 centrum & 1 & & \\
\hline \multicolumn{4}{|l|}{ T12 neural arch } \\
\hline L1 centrum & 1 & & \\
\hline L1 neural arch & 1 & & \\
\hline L2 centrum & 1 & & \\
\hline L2 neural arch & 1 & & \\
\hline L3 centrum & 1 & & \\
\hline L3 neural arch & 1 & & \\
\hline L4 centrum & 1 & & \\
\hline L4 neural arch & 2 & & \\
\hline L5 centrum & 1 & & \\
\hline \multicolumn{4}{|l|}{ L5 neural arch } \\
\hline manubrium & 1 & & \\
\hline sternal body & 1 & & \\
\hline L rib 1 & 1 & & \\
\hline $\mathrm{R}$ rib 1 & 1 & & \\
\hline L rib 2 & 2 & & \\
\hline $\mathrm{R}$ rib 2 & 2 & & \\
\hline L ribs $3-10^{*}$ & $8 / 8$ & $1 / 0$ & \\
\hline $\mathrm{R}$ ribs $3-10^{*}$ & $8 / 8$ & $1 / 0$ & \\
\hline $\mathrm{L}$ rib 11 & 1 & & \\
\hline $\mathrm{R}$ rib 11 & 1 & & \\
\hline L rib 12 & 1 & & \\
\hline $\mathrm{R}$ rib 12 & 1 & & \\
\hline Unsided rib frags.* & & $15 / 0$ & \\
\hline L hum. prox. epiph. & 2 & 1 & \\
\hline L hum. prox. $1 / 3$ & 1 & 1 & 3 \\
\hline L hum. middle $1 / 3$ & 1 & 1 & 3 \\
\hline L hum. dist. $1 / 3$ & 1 & 1 & 3 \\
\hline L hum. dist. epiph. & 1 & 1 & \\
\hline R hum. prox. epiph. & 2 & 2 & \\
\hline $\mathrm{R}$ hum. prox. $1 / 3$ & 1 & 1 & \\
\hline $\mathrm{R}$ hum. middle $1 / 3$ & 1 & 1 & \\
\hline $\mathrm{R}$ hum. dist. $1 / 3$ & 1 & 1 & \\
\hline R hum. dist. epiph. & & 1 & \\
\hline L rad. prox. epiph. & 1 & 1 & \\
\hline L rad. prox. $1 / 3$ & 1 & 1 & \\
\hline L rad. middle $1 / 3$ & 1 & 1 & \\
\hline $\mathrm{L}$ rad. dist. $1 / 3$ & 1 & 1 & \\
\hline L rad. dist. epiph. & & 1 & \\
\hline $\mathrm{R}$ rad. prox. epiph. & 1 & 1 & \\
\hline $\mathrm{R}$ rad. prox. $1 / 3$ & 1 & 3 & \\
\hline $\mathrm{R}$ rad. middle $1 / 3$ & 1 & 2 & \\
\hline $\mathrm{R}$ rad. dist. $1 / 3$ & 1 & & \\
\hline $\mathrm{R}$ rad. dist. epiph. & 1 & & \\
\hline L ulna prox. epiph. & 1 & 2 & \\
\hline L ulna prox. $1 / 3$ & 1 & 1 & \\
\hline L ulna middle $1 / 3$ & 1 & 1 & \\
\hline
\end{tabular}


Table D.1, continued

\begin{tabular}{|c|c|c|c|}
\hline Element & Burial 1 & Burial 3 & Burial 4 \\
\hline L ulna dist. $1 / 3$ & 1 & 1 & \\
\hline \multicolumn{4}{|l|}{ L ulna dist. epiph. } \\
\hline R ulna prox. epiph. & 1 & & \\
\hline R ulna prox. $1 / 3$ & 1 & & \\
\hline $\mathrm{R}$ ulna middle $1 / 3$ & 1 & 2 & \\
\hline $\mathrm{R}$ ulna dist. $1 / 3$ & 1 & 3 & \\
\hline $\mathrm{R}$ ulna dist. epiph. & 1 & & \\
\hline L femur prox. epiph. & 1 & 1 & \\
\hline $\mathrm{L}$ femur prox. $1 / 3$ & 1 & 2 & \\
\hline L femur middle $1 / 3$ & 1 & 1 & \\
\hline $\mathrm{L}$ femur dist. $1 / 3$ & 1 & & \\
\hline L femur dist. epiph. & 3 & 3 & \\
\hline R femur prox. epiph. & 1 & 1 & \\
\hline $\mathrm{R}$ femur prox. $1 / 3$ & 1 & 2 & \\
\hline $\mathrm{R}$ femur middle $1 / 3$ & 1 & 1 & \\
\hline $\mathrm{R}$ femur dist. $1 / 3$ & 1 & 2 & \\
\hline $\mathrm{R}$ femur dist. epiph. & & 3 & \\
\hline L tibia prox. epiph. & 2 & 3 & \\
\hline L tibia prox. $1 / 3$ & 1 & 3 & 3 \\
\hline $\mathrm{L}$ tibia middle $1 / 3$ & 1 & 2 & 3 \\
\hline L tibia dist. $1 / 3$ & 2 & 2 & 3 \\
\hline L tibia dist. epiph. & & 1 & \\
\hline R tibia prox. epiph. & & 2 & \\
\hline $\mathrm{R}$ tibia prox. $1 / 3$ & 1 & 3 & 3 \\
\hline $\mathrm{R}$ tibia middle $1 / 3$ & 1 & 2 & 3 \\
\hline $\mathrm{R}$ tibia dist. $1 / 3$ & 2 & 2 & 3 \\
\hline \multicolumn{4}{|l|}{$\mathrm{R}$ tibia dist. epiph. } \\
\hline \multicolumn{4}{|l|}{ L fibula prox. epiph. } \\
\hline L fibula prox. $1 / 3$ & 1 & 2 & \\
\hline L fibula middle $1 / 3$ & 1 & 1 & \\
\hline L fibula dist. $1 / 3$ & 1 & & \\
\hline L fibula dist. epiph. & 1 & & \\
\hline \multicolumn{4}{|l|}{ R fibula prox. epiph. } \\
\hline $\mathrm{R}$ fibula prox. $1 / 3$ & 2 & & \\
\hline $\mathrm{R}$ fibula middle $1 / 3$ & 1 & 1 & \\
\hline $\mathrm{R}$ fibula dist. $1 / 3$ & 1 & 1 & \\
\hline $\mathrm{R}$ fibula dist. epiph. & 1 & 2 & \\
\hline L talus & 1 & 1 & \\
\hline $\mathrm{R}$ talus & 1 & 1 & \\
\hline L calcaneus & & 1 & \\
\hline $\mathrm{R}$ calcaneus & 2 & 2 & \\
\hline L carpals* & $4 / 4$ & $3 / 3$ & \\
\hline $\mathrm{R}$ carpals* & $4 / 4$ & $4 / 3$ & \\
\hline \multicolumn{4}{|l|}{ Unsided carpals* } \\
\hline L metacarpals* & $4 / 2$ & $1 / 0$ & \\
\hline $\mathrm{R}$ metacarpals* & $5 / 1$ & & \\
\hline \multicolumn{4}{|l|}{ Unsided metacarpals* } \\
\hline L manual phalanges* & $4 / 4$ & $3 / 2$ & \\
\hline $\mathrm{R}$ manual phalanges* & $4 / 4$ & $8 / 7$ & \\
\hline Unsided manual phalanges* & $10 / 9$ & & \\
\hline L tarsals* & $5 / 5$ & $4 / 3$ & \\
\hline
\end{tabular}


Table D.1, continued

\begin{tabular}{l|c|c|c}
\hline Element & Burial 1 & Burial 3 & Burial 4 \\
\hline R tarsals* & $3 / 3$ & $4 / 4$ & \\
\hline Unsided tarsals* & & & \\
\hline L metatarsals* & $5 / 1$ & $2 / 1$ & \\
\hline R metatarsals* & $5 / 0$ & $4 / 2$ & \\
\hline Unsided metatarsals* & & & \\
\hline L pedal phalanges* & $1 / 1$ & $2 / 1$ & \\
\hline R pedal phalanges* & $1 / 1$ & & \\
\hline Unsided pedal phalanges* & $7 / 7$ & & \\
\hline L $=$ left & & & \\
$\mathrm{R}=$ right & & \\
Blank = missing & & \\
$1=75-100 \%$ present; complete & \\
$2=25-75 \%$ present; partial \\
$3=<25 \%$ present; poorly preserved \\
$*=$ grouped elements; number present/number complete
\end{tabular}


Table D.2. Adult sex

\begin{tabular}{|c|c|c|}
\hline Trait & Burial 1 & Burial 3 \\
\hline \multicolumn{3}{|l|}{ L Ventral arc } \\
\hline R Ventral arc & 1 & \\
\hline \multicolumn{3}{|l|}{ L Subpubic concavity } \\
\hline \multicolumn{3}{|l|}{ R Subpubic concavity } \\
\hline \multicolumn{3}{|l|}{ L Ischiopubic ramus ridge } \\
\hline R Ischiopubic ramus ridge & 1 & \\
\hline L Greater sciatic notch & 1 & 1 \\
\hline R Greater sciatic notch & 1 & \\
\hline L Preauricular sulcus* & 2 & 1 \\
\hline R Preauricular sulcus* & 2 & \\
\hline Est. sex-pelvis & 1 & 1 \\
\hline \multicolumn{3}{|l|}{ L Nuchal crest } \\
\hline M Nuchal crest & 1 & 3 \\
\hline \multicolumn{3}{|l|}{ R Nuchal crest } \\
\hline L Mastoid process & 2 & \\
\hline R Mastoid process & 2 & \\
\hline L Supraorbital margin & 2 & 3 \\
\hline R Supraorbital margin & 1 & 3 \\
\hline L Glabella & 1 & 1 \\
\hline \multicolumn{3}{|l|}{ M Glabella } \\
\hline R Glabella & 1 & 1 \\
\hline \multicolumn{3}{|l|}{ L Mental eminence } \\
\hline M Mental eminence & $1-2$ & 1 \\
\hline \multicolumn{3}{|l|}{ R Mental eminence } \\
\hline Est. sex-skull & 1 & 2 \\
\hline Overall sex & 1 & 1 \\
\hline
\end{tabular}

$\mathrm{L}=$ left

$\mathrm{R}=$ right

$\mathrm{M}=$ middle

$0=$ unknown

1 = hyperfeminine, female

2 = feminine, probable female

$3=$ ambiguous

$4=$ masculine, probable male

5 = hypermasculine, male

*Pre-auricular sulcus scores

0 -sulcus absent

1 -sulcus is wide and deep

2 -sulcus is wide and shallow

3 -sulcus is well-defined but narrow

4-sulcus is narrow, shallow, and smooth-walled depression 
Table D.3. Adult age

\begin{tabular}{l|c|c}
\hline Age criteria & Burial 1 & Burial 3 \\
\hline L Pub. symph. Todd phase* & & \\
\hline R Pub. symph. Todd phase* & 1 & \\
\hline L Pub. symph. Suchey-Brooks phase* & & \\
\hline R Pub. symph. Suchey-Brooks phase* & 1 & \\
\hline L Auricular surface* & & $5-6$ \\
\hline R Auricular surface* & & $5-6$ \\
\hline Midlambdoid & & 3 \\
\hline Lambda & & \\
\hline Obelion & & 2 \\
\hline Anterior-Sagittal & & \\
\hline Bregma & & \\
\hline Midcoronal & & \\
\hline Pterion & & \\
\hline Sphenofrontal & & \\
\hline Inf. sphenotemporal & & \\
\hline Sup. sphenotemporal & & \\
\hline Incisive & & 3 \\
\hline Ant. median palatine & & \\
\hline Post. median palatine & & \\
\hline Transverse palatine & & \\
\hline Sagittal (internal) & & \\
\hline L Lambdoid (internal) & & \\
\hline L Coronal (internal) & & \\
\hline Estimated age & & \\
\hline Blank urs. & $45-60$ yrs. \\
\hline
\end{tabular}

Blank = unobservable

$0=$ open

$1=$ minimal

$2=$ significant

$3=$ complete

*See Buikstra and Ubelaker (1994) for phase descriptions 
Table D.4. Bone union and ephiphyseal closure

\begin{tabular}{|c|c|}
\hline Element & Burial 1 \\
\hline Cervical vert., superior & 1 \\
\hline Cervical vert., inferior & 1 \\
\hline Thoracic vert., superior & 1 \\
\hline Thoracic vert., inferior & 1 \\
\hline Lumbar vert., superior & 1 \\
\hline Lumbar vert., inferior & 1 \\
\hline \multicolumn{2}{|l|}{ L coracoid } \\
\hline \multicolumn{2}{|l|}{$\mathrm{R}$ coracoid } \\
\hline \multicolumn{2}{|l|}{ L acromion } \\
\hline \multicolumn{2}{|l|}{$\mathrm{R}$ acromion } \\
\hline L clavicle-sternal & 0 \\
\hline R clavicle-sternal & 0 \\
\hline L humeral head & 1 \\
\hline \multicolumn{2}{|l|}{$\mathrm{R}$ humeral head } \\
\hline L dist. humerus & 2 \\
\hline \multicolumn{2}{|l|}{$\mathrm{R}$ dist. humerus } \\
\hline L medial epicondyle & 2 \\
\hline \multicolumn{2}{|l|}{$\mathrm{R}$ medial epicondyle } \\
\hline \multicolumn{2}{|l|}{ L prox. radius } \\
\hline $\mathrm{R}$ prox. radius & 1 \\
\hline \multicolumn{2}{|l|}{$\mathrm{L}$ distal radius } \\
\hline $\mathrm{R}$ distal radius & 1 \\
\hline \multicolumn{2}{|l|}{ L prox. ulna } \\
\hline $\mathrm{R}$ prox. ulna & 1 \\
\hline \multicolumn{2}{|l|}{ L distal ulna } \\
\hline $\mathrm{R}$ distal ulna & 1 \\
\hline \multicolumn{2}{|l|}{ L iliac crest } \\
\hline \multicolumn{2}{|l|}{$\mathrm{R}$ iliac crest } \\
\hline \multicolumn{2}{|l|}{ L ischial tuberosity } \\
\hline \multicolumn{2}{|l|}{$\mathrm{R}$ ischial tuberosity } \\
\hline L femoral head & 1 \\
\hline $\mathrm{R}$ femoral head & 1 \\
\hline \multicolumn{2}{|l|}{ L gr. trochanter } \\
\hline \multicolumn{2}{|l|}{ R gr. trochanter } \\
\hline \multicolumn{2}{|l|}{ L lsr. trochanter } \\
\hline R lsr. trochanter & 2 \\
\hline \multicolumn{2}{|l|}{ L distal femur } \\
\hline \multicolumn{2}{|l|}{$\mathrm{R}$ distal femur } \\
\hline \multicolumn{2}{|l|}{ L prox. tibia } \\
\hline \multicolumn{2}{|l|}{$\mathrm{R}$ prox. tibia } \\
\hline L distal tibia & \\
\hline $\mathrm{R}$ distal tibia & \\
\hline L prox. fibula & \\
\hline $\mathrm{R}$ prox. fibula & \\
\hline L distal fibula & 1 \\
\hline $\mathrm{R}$ distal fibula & 1 \\
\hline ilium-pubis & 2 \\
\hline ischium-pubis & 2 \\
\hline ischium-ilium & 2 \\
\hline S1-S2 & \\
\hline S2-S3 & \\
\hline
\end{tabular}


Table D.4, continued

\begin{tabular}{l|c}
\hline Element & Burial 1 \\
\hline S3-S4 & \\
\hline S4-S5 & 2 \\
\hline cervical neural arch halves & 2 \\
\hline cervical neural arches to centrum & 2 \\
\hline thoracic neural arch halves & 2 \\
\hline thoracic neural arches to centrum & 2 \\
\hline lumbar neural arch halves & 2 \\
\hline lumbar neural arches to centrum & 2 \\
\hline spheno-occipital synchondrosis & 2 \\
\hline lateral occipital to squama & \\
\hline basilar occipital to lateral & $17-23$ yrs. \\
\hline Other &
\end{tabular}

Blank = not observable

$0=$ open

$1=$ partial union

2 = complete union 
Table D.5. Cranial measurements in adults

\begin{tabular}{l|c}
\hline Measurement & Burial 1 \\
\hline Max. length & \\
\hline Max. breadth & \\
\hline Bizygomatic diam. & \\
\hline Basion-bregma height & \\
\hline Crainal base length & \\
\hline Maxillo-alveolar breadth & \\
\hline Maxillo-alveolar length & \\
\hline Biauricular breadth & \\
\hline Upper facial height & \\
\hline Min. frontal breadth & \\
\hline Upper facial breadth & \\
\hline Nasal height & \\
\hline Nasal breadth & \\
\hline Orbital breadth & \\
\hline Orbital height & \\
\hline Biorbital breadth & \\
\hline Interorbital breadth & \\
\hline Frontal chord & \\
\hline Parietal chord & \\
\hline Occipital chord & \\
\hline Foramen magnum length & \\
\hline Foramen magnum breadth & \\
\hline Mastoid length & \\
\hline Chin height & \\
\hline Height of mandibular body & \\
\hline Breadth of mandibular body & \\
\hline Bigonial width & \\
\hline Bicondylar breadth & \\
\hline Min. ramus breadth & \\
\hline Max. ramus height & \\
\hline Mandibular length & \\
\hline Mandibular angle & \\
\hline Notes: Left side standard; & \\
\hline
\end{tabular}

Notes: Left side standard; (R) would indicate that measurement was taken from the right side. Measurements are in millimeters. Blank $=$ not observable. 
Table D.6. Postcranial measurements in adults

\begin{tabular}{|c|c|c|}
\hline Measurement & Burial 1 & Burial 3 \\
\hline Clavicle: max. length & 129 & \\
\hline Clavicle: A-P diam. at midshaft & $11 *$ & $11^{*}$ \\
\hline Clavicle: S-I diam. at midshaft & $8 *$ & $9 *$ \\
\hline \multicolumn{3}{|l|}{ Scapula: height } \\
\hline \multicolumn{3}{|l|}{ Scapula: breadth } \\
\hline \multicolumn{3}{|l|}{ Humerus: max. length } \\
\hline Humerus: epicondylar length & 56 & 58 \\
\hline \multicolumn{3}{|l|}{ Humerus: vert. diam. of head } \\
\hline Humerus: Max. diam. at midshaft & $19 *$ & $22 *$ \\
\hline Humerus: Min. diam. at midshaft & $17 *$ & $18^{*}$ \\
\hline \multicolumn{3}{|l|}{ Radius: max. length } \\
\hline \multicolumn{3}{|l|}{ Radius: A-P diam. at midshaft } \\
\hline \multicolumn{3}{|l|}{ Radius: M-L diam. at midshaft } \\
\hline Ulna: max. length. & 255 & \\
\hline Ulna: A-P diam. & 15 & \\
\hline Ulna: M-L diam. & 16 & \\
\hline Ulna: physiological length & 226 & \\
\hline Ulna: min. circumference & 35 & \\
\hline \multicolumn{3}{|l|}{ Sacrum: A length } \\
\hline \multicolumn{3}{|l|}{ Sacrum: A S breadth } \\
\hline \multicolumn{3}{|l|}{ Sacrum: max. transverse diam. base } \\
\hline \multicolumn{3}{|l|}{ Os coxae: height } \\
\hline \multicolumn{3}{|l|}{ Os coxae: iliac breadth } \\
\hline \multicolumn{3}{|l|}{ Os coxae: pubis length } \\
\hline \multicolumn{3}{|l|}{ Os coxae: ischium length } \\
\hline \multicolumn{3}{|l|}{ Femur: max. length } \\
\hline \multicolumn{3}{|l|}{ Femur: bicondylar length } \\
\hline \multicolumn{3}{|l|}{ Femur: epicondylar breadth } \\
\hline Femur: max. diam. of head & 37 & 45 \\
\hline \multicolumn{3}{|l|}{ Femur: A-P subtrochanteric diam. } \\
\hline Femur: M-L subtrochanteric diam. & 26 & \\
\hline \multirow{2}{*}{\multicolumn{3}{|c|}{$\begin{array}{l}\text { Femur: A-P midshaft diam. } \\
\text { Femur: M-L midshaft diam. }\end{array}$}} \\
\hline & & \\
\hline \multicolumn{3}{|l|}{ Femur: midshaft circumference } \\
\hline \multicolumn{3}{|l|}{ Tibia: length } \\
\hline \multicolumn{3}{|l|}{ Tibia: max. prox. epiphyseal length } \\
\hline \multicolumn{3}{|l|}{ Tibia: max. dist. epiphyseal length } \\
\hline Tibia: max. diam. at nutrient foramen & 31 & \\
\hline Tibia: M-L diam. at nutrient foramen & 23 & \\
\hline Tibia: circumference at nutrient foramen & 86 & \\
\hline \multicolumn{3}{|l|}{ Fibula: max. length } \\
\hline \multicolumn{3}{|l|}{ Fibula: max. diam. at midshaft } \\
\hline Calcaneus: max. length & & \\
\hline Calcaneus: middle breadth & & \\
\hline $\begin{array}{l}\text { Notes: Left side standard; }(\mathrm{R}) \text { would indica } \\
\text { the right side. Measurements are in millim } \\
*=\text { midshaft location estimated } \\
\mathrm{A}=\text { anterior } \\
\mathrm{P}=\text { posterior } \\
\mathrm{S}=\text { superior } \\
\mathrm{I}=\text { inferior } \\
\mathrm{M}=\text { medial } \\
\mathrm{L}=\text { lateral }\end{array}$ & $\begin{array}{l}\text { uremen } \\
=\text { not ol }\end{array}$ & $\begin{array}{l}\text { taken f } \\
\text { ble. }\end{array}$ \\
\hline
\end{tabular}


Table D.7. Primary nonmetric traits

\begin{tabular}{|c|c|c|}
\hline Trait & Burial 1 & Burial 3 \\
\hline Metopic suture & 0 & 9 \\
\hline L supraorbital notch & 1 & 0 \\
\hline $\mathrm{R}$ supraorbital notch & 0 & 0 \\
\hline L supraorbital foramen & 0 & 1 \\
\hline $\mathrm{R}$ supraorbital foramen & 1 & 1 \\
\hline L infraorbital suture & 9 & 9 \\
\hline $\mathrm{R}$ infraorbital suture & 9 & 9 \\
\hline L mult. infraorbital foramina & 9 & 9 \\
\hline $\mathrm{R}$ mult. infraorbital foramina & 9 & 9 \\
\hline L zygomatico-facial foramina & 1 & 4 \\
\hline $\mathrm{R}$ zygomatico-facial foramina & 1 & 3 \\
\hline L parietal foramen & 1 & 1 \\
\hline $\mathrm{R}$ parietal foramen & 2 & 1 \\
\hline L epipteric bone & 9 & 9 \\
\hline $\mathrm{R}$ epipteric bone & 9 & 9 \\
\hline L coronal ossicle & 9 & 9 \\
\hline $\mathrm{R}$ coronal ossicle & 9 & 9 \\
\hline Bregmatic bone & 9 & 9 \\
\hline Sagittal ossicle & 9 & 9 \\
\hline Apical bone & 9 & 9 \\
\hline L lambdoid ossicle & 9 & 9 \\
\hline R lambdoid ossicle & 9 & 9 \\
\hline L asterionic bone & 9 & 9 \\
\hline $\mathrm{R}$ asterionic bone & 9 & 9 \\
\hline L ossicle in occipito-mastoid suture & 9 & 9 \\
\hline $\mathrm{R}$ ossicle in occipito-mastoid suture & 9 & 9 \\
\hline L parietal notch bone & 9 & 9 \\
\hline $\mathrm{R}$ parietal notch bone & 9 & 9 \\
\hline Inca bone & 0 & 0 \\
\hline L condylar canal & 9 & 9 \\
\hline $\mathrm{R}$ condylar canal & 9 & 9 \\
\hline L divided hypoglossal canal & 0 & 0 \\
\hline $\mathrm{R}$ divided hypoglossal canal & 0 & 0 \\
\hline Flexure of superior sagittal sulcus & 1 & 1 \\
\hline L foramen ovale incomplete & 9 & 9 \\
\hline $\mathrm{R}$ foramen ovale incomplete & 1 & 9 \\
\hline L foramen spinosum incomplete & 9 & 9 \\
\hline $\mathrm{R}$ foramen spinosum incomplete & 0 & 9 \\
\hline L pterygo-spinous bridge & 9 & 9 \\
\hline R pterygo-spinous bridge & 0 & 9 \\
\hline L pterygo-alar bridge & 9 & 9 \\
\hline $\mathrm{R}$ pterygo-alar bridge & 0 & 9 \\
\hline L tympanic dihiscence & 9 & 9 \\
\hline $\mathrm{R}$ tympanic dihiscence & 9 & 9 \\
\hline L auditory exostoses & 0 & 9 \\
\hline $\mathrm{R}$ auditory exostoses & 0 & 9 \\
\hline L mastoid foramen location & 9 & 9 \\
\hline $\mathrm{R}$ mastoid foramen location & 1 & 9 \\
\hline L mastoid foramen number & 9 & 9 \\
\hline $\mathrm{R}$ mastoid foramen number & 1 & 9 \\
\hline
\end{tabular}


Table D.7, continued

\begin{tabular}{|c|c|c|}
\hline Trait & Burial 1 & Burial 3 \\
\hline L mental foramen & 1 & 1 \\
\hline $\mathrm{R}$ mental foramen & 1 & 1 \\
\hline L mandibular torus & 0 & 9 \\
\hline $\mathrm{R}$ mandibular torus & 0 & 2 \\
\hline L mylohyoid bridge location & 0 & 2 \\
\hline $\mathrm{R}$ mylohyoid bridge location & 0 & 9 \\
\hline L mylohyoid bridge degree & 0 & 1 \\
\hline R mylohyoid bridge degree & 0 & 9 \\
\hline L lateral atlas bridging & 0 & 0 \\
\hline $\mathrm{R}$ lateral atlas bridging & 0 & 1 \\
\hline L posterior atlas bridging & 0 & 0 \\
\hline $\mathrm{R}$ posterior atlas bridging & 0 & 0 \\
\hline L accessory transverse foramina (C7) & 9 & 9 \\
\hline $\mathrm{R}$ accessory transverse foramina $(\mathrm{C} 7)$ & 9 & 9 \\
\hline L septal aperture & 2 & 0 \\
\hline $\mathrm{R}$ septal aperture & 2 & 0 \\
\hline
\end{tabular}

Note: See Buikstra and Ubelaker (1994) for code definitions.

$\mathrm{L}=$ left

$\mathrm{R}=$ right

$\mathrm{C}=$ cervical 


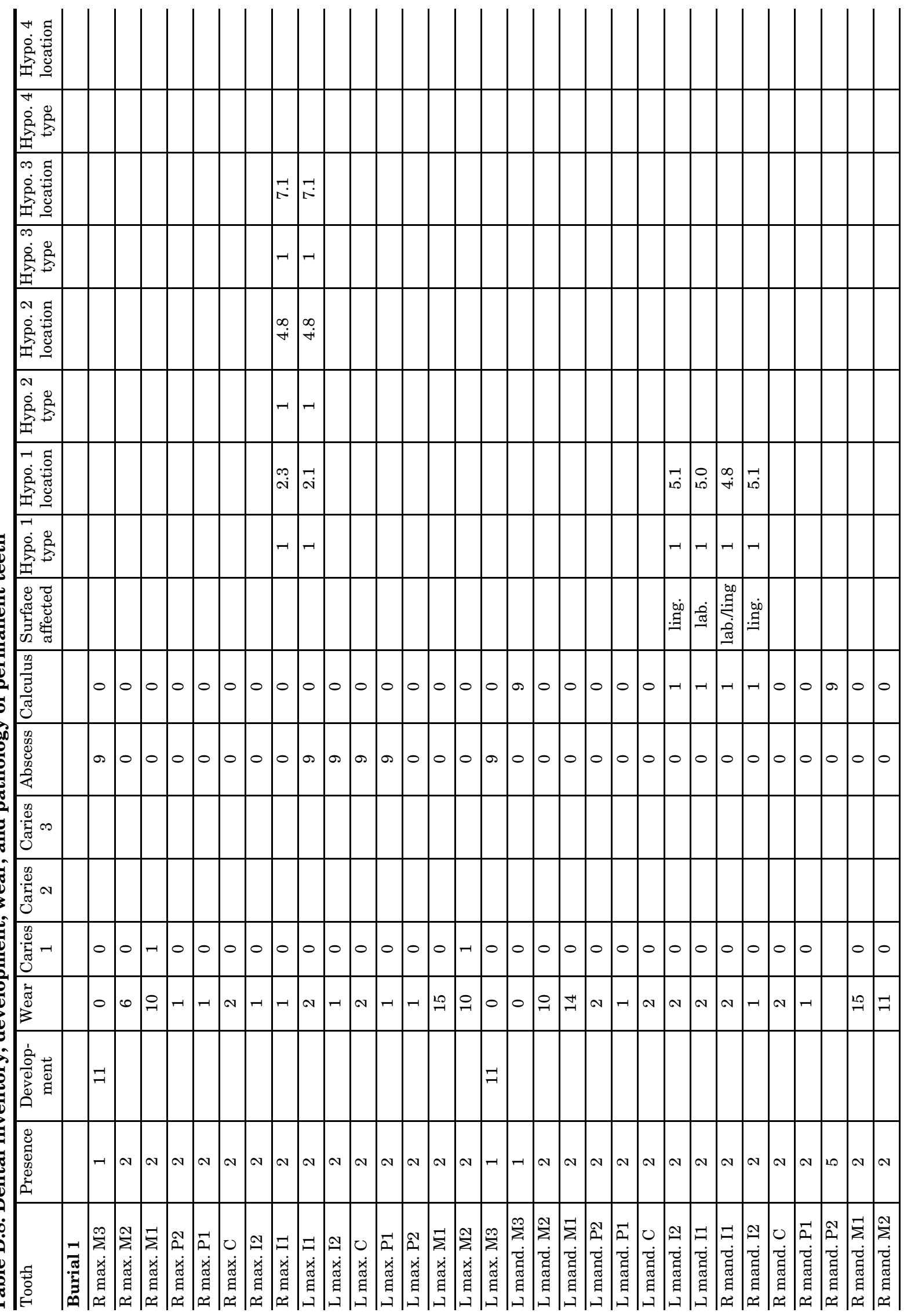


Excavation and Reburial of Unmarked Historic Graves in the Pioneer Cemetery

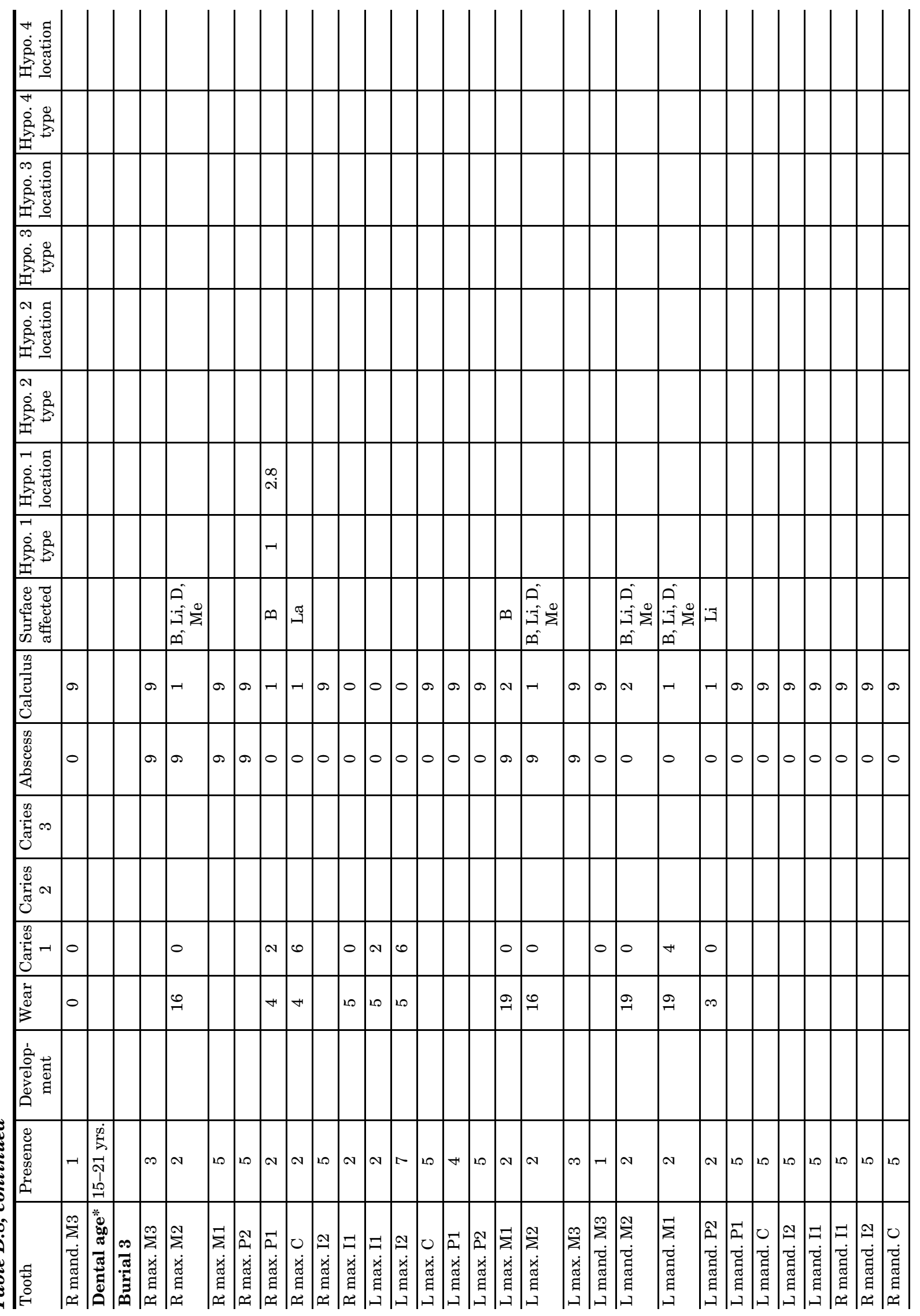




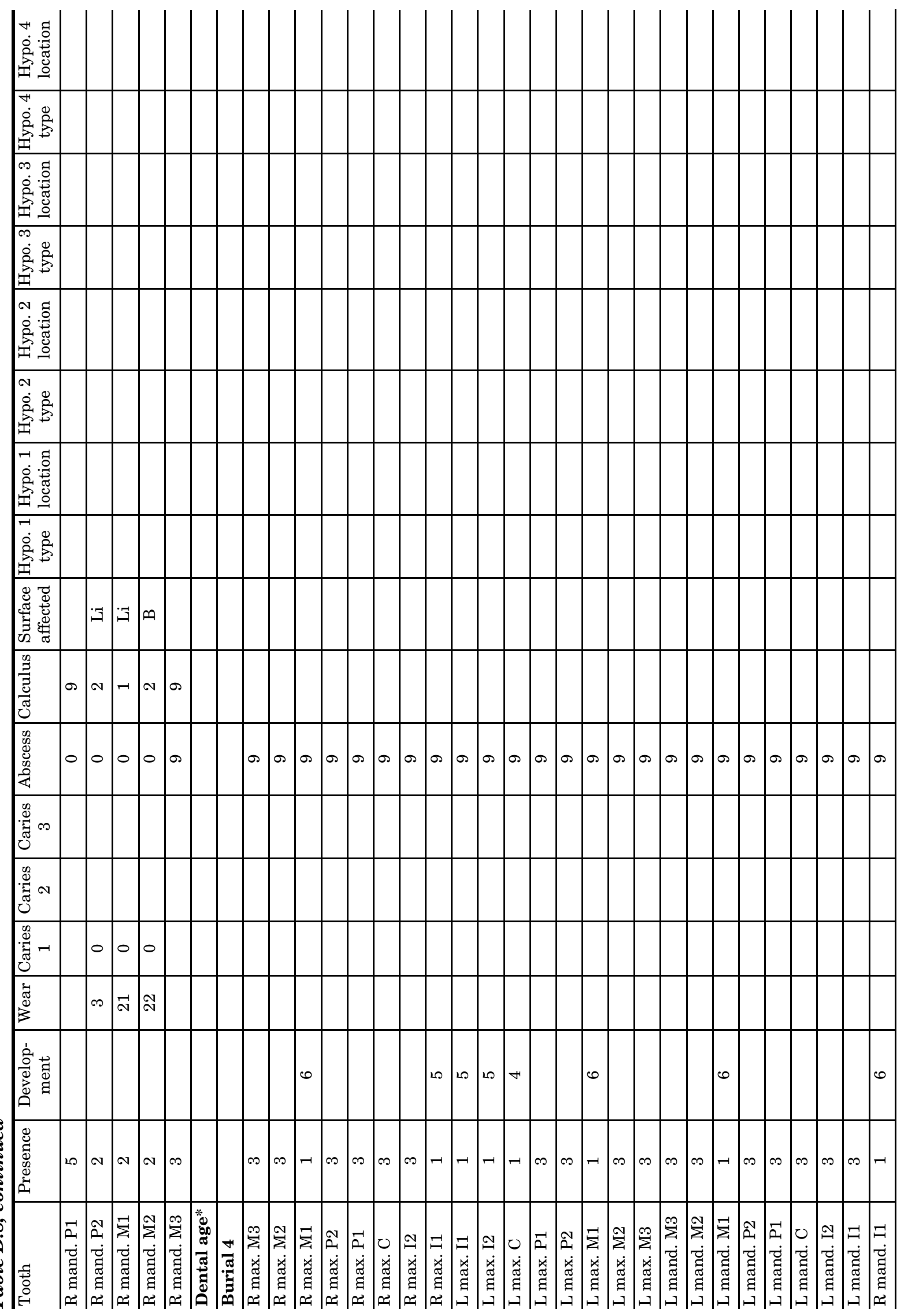


Excavation and Reburial of Unmarked Historic Graves in the Pioneer Cemetery

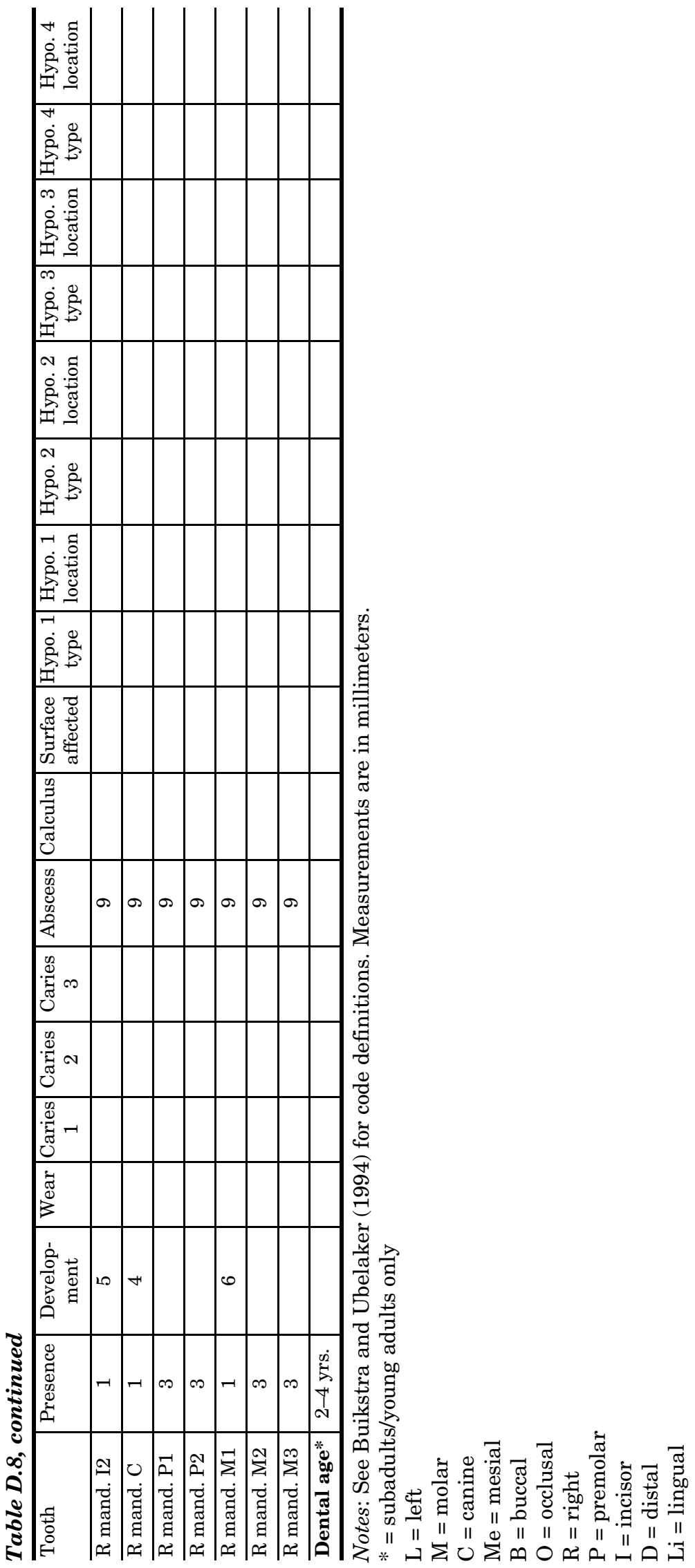




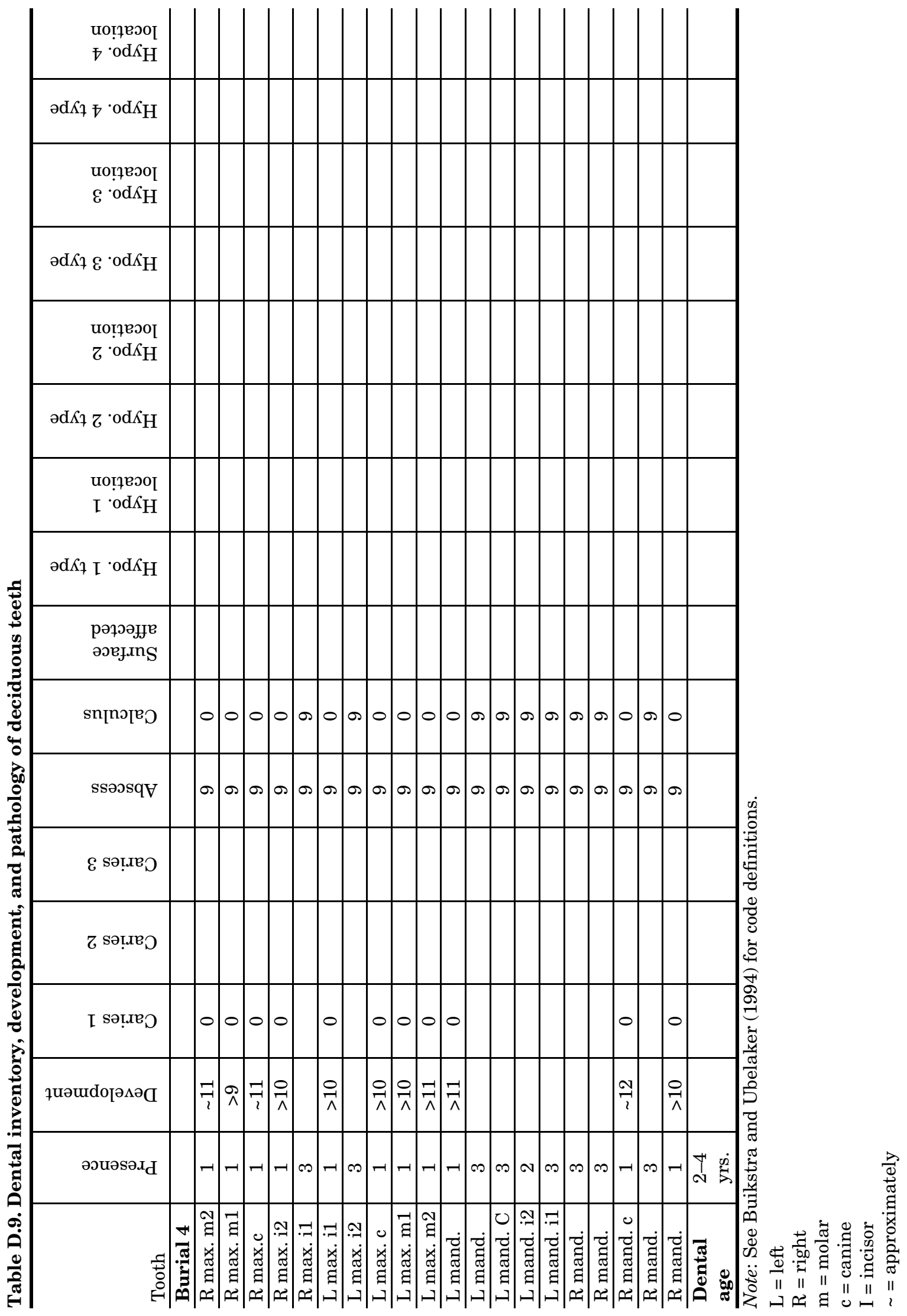

